\title{
R.4259 MASTER
}

\section{OXYGEN SUPPRESSION IN BOILING-WATER REACTORS \\ QUARTERLY REPORT 4 JULY 1 TO SEPTEMBER 30, 1978}

\author{
E. L. BURLEY
}

CONTRACT DE-AC02-76ET34203

COMMONWEALTH RESEARCH CORPORATION U.S. DEPARTMENT OF ENERGY 


\section{DISCLAIMER}

This report was prepared as an account of work sponsored by an agency of the United States Government. Neither the United States Government nor any agency Thereof, nor any of their employees, makes any warranty, express or implied, or assumes any legal liability or responsibility for the accuracy, completeness, or usefulness of any information, apparatus, product, or process disclosed, or represents that its use would not infringe privately owned rights. Reference herein to any specific commercial product, process, or service by trade name, trademark, manufacturer, or otherwise does not necessarily constitute or imply its endorsement, recommendation, or favoring by the United States Government or any agency thereof. The views and opinions of authors expressed herein do not necessarily state or reflect those of the United States Government or any agency thereof. 


\section{DISCLAIMER}

Portions of this document may be illegible in electronic image products. Images are produced from the best available original document. 


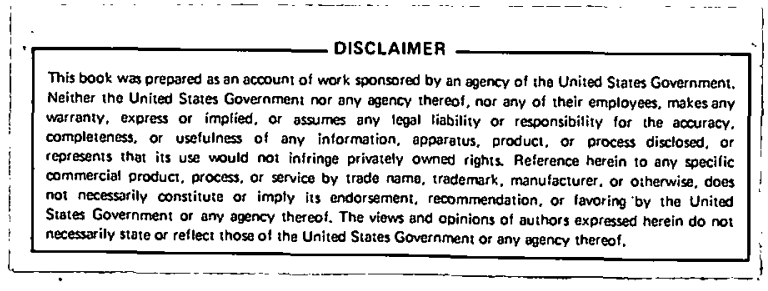

$\mathrm{DOE} / \mathrm{ET} / 34203-38$

NEDC-23856-3

March 1979

OXYGEN SUPPRESSION IN BOILING-WATER REACTORS

QUARTERLY REPORT 4

July 1 to September 30, 1978

Under Contract DE-ACO2-76ET34203

Prepared by E. L. Burley

for the Commonwealth Research Corp.

and the U.S. Department of Energy

Reviewed:

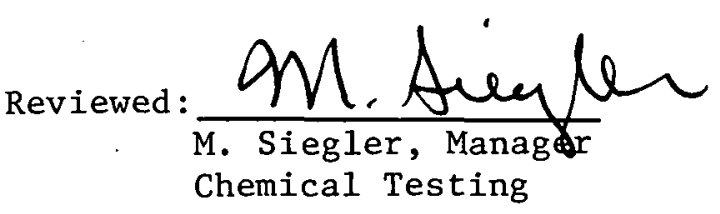

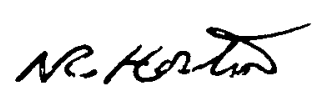

Reviewed:

W. R. DeHollander, Manager Chemical and Radiological Engineering

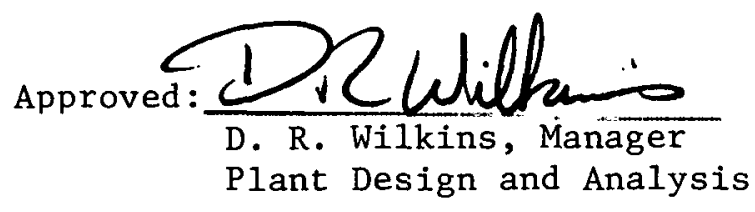

Program Manager for Commonwealth Research Corp.: J. C. Blomgren Program Manager for the U.S. Department of Energy: P. M. Lang 
This report was prepared by the General Electric Company (GE) as an account of work sponsored by the Department of Energy (DOE). Neither DOE, members of DOE, nor GE, nor any person acting on behalf of either, including Commonwealth Research Corporation:

a. Makes any warranty or representation, express or implied, with respect to the accuracy, completeness, or usefulness of the information contained in this report.; or that the use of any information, apparatus, method, or process disclosed in this reportsmay not infringe privately owned rights; or

b. Assumes any liabilities with respect to the use of; or for domagoo rooulting from tho uos of, any information, apparatus, method, or process disclosed in this report. 
CONTENTS

\section{ACKNOWLEDGMENTS}

2. SUMMARY

2.1 Mass Balance Flow Sheets

2.2 Turbine Building Radiation Levels

2.3 Steam Activity

$2-1$

2.4 Off-Gas Impurities

$2-1$

2.5 Off-Gas System Modifications

$2-2$

2.6 Condenser Coolant Leakage Monitoring

2.7 Constant Extension Rate Tests

$2-2$

2.8 Straining Electrode Tests . 2-2

2.9 Demineralizer Performance $2-3$

2.10 Radwaste System Impact . 2-3

2.11 Additive Injection System $2-3$

2.12 Emergency Core Cooling System and Loss-of-Coolant Accident Analyses

2.13 Radioactivity Transport

2.14 Additive Consumption and Source

3.1 Task A. $\mathrm{O}_{2}$ Control - Mass Balance Flow Sheets

(T. L. Wong)

3.1.1 Additional Flow Sheet Considerations 3-1

3.1.2 Hydrogen Addition 3-1

3.1.3 Hydrazine Addition 3-2

3.2 Task B-1. N-16 Dose Rate (H. H. Paustian, G. F. Palino) 3-5

3.2.1 Dose Rate Calculations 3-5

3.2.2 N-16 Activity Level 3-30

3.2.3 Carbon Chemistry 3-32

3.2.4 Expected Dose Rates 3-34

3.3 Task B-2. Additive Volatility/Decomposition -
Off-Gas System Modification (R. J. Law) 3-37

$\begin{array}{lll}\text { Off-Gas System Modification (R. J. Law) } & 3-37 \\ 3.3 .1 & \text { Off-Gas Base Line Impurity Measurements } & 3-37\end{array}$

3.3.2 Off-Gas System Mass Balances 3-49

3.3.3 Current Activities 3-52

3.4 Task B-3. Coolant Leakage Monitoring (L. L. Sundberg) 3-57

$\begin{array}{ll}3.4 .1 & \text { Chloride Monitor 3-57 }\end{array}$

$\begin{array}{ll}3.4 .2 & \text { Instrument Calibration 3-57 }\end{array}$

3.4.3 Instrument Stability and Sensitivity Testing 3-59

3.4.4 System Modifications 3-63

3.5 Task B-4. Plant Materials Compatibility (B. M. Gordon) 3-64

3.5,1 Constant Extension Rate Tests (F. P. Ford, Corporate

Research and Development Center, Schenectady, N.Y.) 3-64

3.5.2 Hydrogen Addition Tests 3-69

3.5.3 Straining Electrode Tests (M. Indig) 3-69

3.6 Task B-5. Demineralizer Performance (W. L. Lewis,
L. L. Sundberg)

3.6.1 Performance Predictions 3-75 
CONTENTS (Continued)

3.6 .2 Resin Testing $3-76$

3.6.3 Analytical Systems 3-78

3.6.4 Test Plan 3-80

3.7 Task B-6. - Radwaste System Impact (E. L. Burley) 3-81

3.7.1 System Changes 3-81

3.7.2 Alternatives 3-81

3.8 Task B-7. Injection and Control Equipment

(J. D. Seymour, N. A. Fedrick) $\quad 3-84$

$\begin{array}{lll}3.8 .1 & \text { Hydrogen Injection System Selection } & 3-84 \\ 3.8 .2 & \text { Design } & 3-88\end{array}$

3.8.3 Results 3-93

3.8.4 Conclușions and Reçommendations 3-93

3.8.5 Cost Analysis 3-95

3.y l'ask B-8. Operational and Other Related Considerations

(R. J. Stevens, T. L. Wong, E. G, Ten, R. S. Shiralkar,

J. J. Uuncan, C. C. Lin, J. S. Wiley) 3-98

3.9.1 Additive Surveillance Requirements 3-98

3.9.2 Operational Guidelines 3-99

3.9.3 Special Training 3-1.00

3.9.4 Special Equipment 3-100

3.9.5 Ammonia Detection Methods 3-101

3.9.6 Hydrazine Detection Methods 3-102

3.9.7 Hydrogen Detection 3-102

3.9.8 Additional Procedure Requirements 3-104

3.9.9 Emergency Core Cooling Systell 3-104

3.9.10 Post-LOCA Hydrogen Concentrations 3-104

3.9.11 Crud and Radioactivity Transport and Build-Up 3-104

3.10 Task B-9. Additive Consumption and Source (T. L. Wong) 3-110

3.10 .1 Hydrogen Recyele $3=110$
3.10 .2

3.10.2 Membrane Separation Process 3-110

3.10.3 Metallic Membrane Processes 3-112

3.10.4 System Size 3-112

3.10.5 Sponge Alloy Separations 3-114

4. REFERENCES $4-1$

\section{APFENDICES}

A. EQUIPMENT LIST - HYDROGEN INJECTION SYSTEM A-1

B. SAMPLE CALCULATIONS B-1

DISTRIBUTION 1 
NEDC-23856-3

\section{ILLUSTRATIONS}

\begin{tabular}{|c|c|c|}
\hline Figure & Title & Page \\
\hline $3-1$ & Hydrazine Decomposition Rates versus Temperature & $3-3$ \\
\hline $3-2$ & $\begin{array}{l}\text { Hydrazine Addition - Hydrazine Controlling Case (Using } \\
\text { Japanese thermal decomposition data) }\end{array}$ & $3-4$ \\
\hline $3-3$ & Configuration of Steam Lines (pictorial) & $3-7$ \\
\hline $3-4$ & Dresden 2 Steam Line Geometry & $3-8$ \\
\hline $3-5$ & Dresden 2 Turbine Operating Floor & $3-10$ \\
\hline $3-6$ & Turbine Operating Floor Arrangement for BWR/6 Calculations & $3-21$ \\
\hline $3-7$ & Detector Locations Near MSR & $3-24$ \\
\hline $3-8$ & Geometry for Combined Source QAD-F Dose Rate Calculation & $3-27$ \\
\hline $3-9$ & Off-Gas Sampling System & $3-39$ \\
\hline $3-10$ & Gas Chromatograph Sampling System & $3-41$ \\
\hline $3-11$ & Mass Spectrometer.Sampling System & $3-42$ \\
\hline $3-12$ & Ozone Monitoring Sampling System & $3-43$ \\
\hline $3-13$ & $\left(\mathrm{NO} \mathrm{NO}_{2}\right)$ Drag̈er Adsorption Tube Sampling System & $3-44$ \\
\hline $3-14$ & Gas Chromatograph Internal Flow Paths & $3-45$ \\
\hline $3-15$ & $\begin{array}{l}\text { Hydrogen Addition-10 ppb Oxygen in Core Exit Water } \\
\text { (One Pass for Hydrogen) }\end{array}$ & $3-50$ \\
\hline $3=16$ & $\begin{array}{l}\text { Hydrugen Addiliun-50 pyl Oxygen ill Cuĩe Exil Walei } \\
\text { (One Pass for Hydrogen) }\end{array}$ & $3-51$ \\
\hline $3-17$ & $\begin{array}{l}\text { Hydrogen Addition- } 10 \mathrm{ppb} \text { Oxygen in Core Exit Water } \\
\text { (One Pass for Hydrogen and Oxygen Addition to } \\
\text { Recombine Hydrogen) }\end{array}$ & $3-53$ \\
\hline $3-18$ & $\begin{array}{l}\text { Hydrogen Addition-50 ppb oxygen in Core Exit wacer } \\
\text { (One Pass for Hydrogen and Oxygen Addition to } \\
\text { Recomblne Hydrogen) }\end{array}$ & $3-54$ \\
\hline 3-19 & Oxygen Addition System & $3-55$ \\
\hline
\end{tabular}


NEDC-23856-3

\section{ILLUSTRATIONS (Continued)}

Figure

Title

Page

3-20 Chloride and Sodium Monitor Variation With Sample Flow Rate

3-21 Crack Propagation Rate versus Oxygen Content for Smooth Samples

3-22 Crack Propagation Rate versus Oxygen Content for Notched Samples

3-23 Straining Electrode Apparatus

3-24 Refreshed Water Loop for Electrochemical Studies

$3-71$

3-25 Resin Test System

$3-77$

3-26 Column Etticiency versus Superficial Gas Velocity

3-27 Comparison of Liquid-Phase Mass Transfer Coefficients

3-28 Correlation for $\mathrm{K}_{\mathrm{L}}$ a Based on $\mathrm{O}_{2}-\mathrm{H}_{2} \mathrm{O}$ system

$3-91$

3-29 Absorption Curve for Hydrogen in Water

$3-94$

3-30 Hydrogen Gas Mixing Section

$3-95$

3-31 P\&ID for Hydrogen Injection System

$3-96$

3-32 Drywell Hydrogen Concentration versus Time After LOCA

3-106

3-33 BWR Fue1 Deposit Deposition

3-109

3-34 Membrane Separation Unit

$3-111$

3-35 Mass Balance Flow Sheet with Hydrogen Separation

3-113 


\section{TABLES}

Table

Title

Page

3-1 "C" Steam Line Dose Rate Measurements

3-6

3-2 QAD-F Calculated Exposure Rates

$3-7$

3-3 Ratio of Measured Exposure Rates to QAD-F Calculated Exposure Rates

3-9

3-4 Mass Flow Conditions in Turbine Components on Dresden 2 Operating Floor at $100 \%$ Power

3-5 Contained Inventories in D-2 Turbine Equipment 3-12

3-6 N-16 Operating Floor Dose Rates 3-14

3-7 C-15 Operating Floor Dose Rates 3-15

3-8 Equivalent Point Sources for D-2 Air-Scattering Calculation 3-17

3-9 Detector Locations for Dresden 2 Air-Scatter Calculation 3-18

3-10 Air-Scatter Exposure Rates from Dresden 2 Turbine

Components Above Turbine Operating Floor

3-11 Mass Flow Conditions in Turbine Components on BWR/ 6

Operating Floor at $100 \%$ Power $3-22$

3-12 Contained Inventories in BWR/6 Turbine Equipment 3-23

3-13 QAD-F Calculated Dose Rates Near BWR/6 MSR 3-24

3-14 QAD-F Calculated Dose Rates on Other Side of Shield Wa11 Adjacent to an MSR 3-25

3-15 QAD-F Calculated Dose Rates Near the High Pressure Turbine 3-25

3-16 QAD-F Calculated N-16 Dose Rates for Combined Sources

Near High Pressure End of Turbine 3-26

3-17 QAD-F Calculated C-15 Dose Rates for Combined Sources 3-27

3-18 Equivalent Point Sources for BWR/6 Air-Scattering Calculation 3-29

3-19 Air-Scatter Exposure Rates from BWR/6 Turbine Components 3-29

3-20 Effect of Hydrogen Addition on N-16 Steam Line Activity 3-31

3-21 Yield of C-11 Products in Aqueous Solutions Irradiated

3-22 Estimated Dresden 2 Turbine Operating Floor Dose Rates for Proposed Hydrogen Additive Flow Sheet 3-36

3-23 Instrumentation 3-40

3-24 Offgas Impurity Concentrations at Nine Mile Point 1,

3-25 Qualitative Results of Various Adsorption Tubes to Off-Gas
Samples

3-26 $\mathrm{O}_{2}$ Addition System Equipment and Installation Cost 3-56 
NEDC-23856-3

TABLES (Continued)

Table

Title

Page

3-27 Chloride Monitor Performance

3-28 Effect of Ammonia on Stress Corrosion Cracking of Type-304 Stainless Steel at $288^{\circ} \mathrm{C}$

3-29 Straining Electrode Results for Welded Type-304 Stainless Steel (Heat No. 1) at $274^{\circ} \mathrm{C}$ in $0.1 \mathrm{~N} \mathrm{Na}_{2} \mathrm{SO}_{4}$

$3-73$

3-30 Resin Regeneration Waste

3-82

3-31 Recommended Design Criteria

3-84

3-32 A Comparison of Four Gas-Liquid Contacting Devices

$3-86$

3-33 Cost Estimate for Hydrogen Injection System

3-97

3-34 Additive Concentration Limits in Air

3-98.

3-35 Operating Conditions of Neutral, Boiling Water Loop Test From AECL, September 1978

3-107

3-36 Fuel Deposit Data from Boiling Loop Test from AECL, September 1978

$3-108$ 
NEDC-23856-3

\section{ACKNOWLEDGEMENTS}

The information and insights contributed to this program by the management and scientists of the Chalk River Laboratories of Atomic Energy of Canada Limited are gratefully acknowledged. Their willingness to share their thoughts and experience in so many areas pertinent to this Alternate Water Chemistry study has been of great assistance and is deeply appreciated by the program investigators and sponsors. 


\section{INTRODUCTION}

Boiling water reactors (BWR's) generally use high purity, no-additive feedwater. The primary recirculating coolant is neutral pH, and contains 100 to $300 \mathrm{ppb}$ oxygen with stoichiometrically related dissolved hydrogen. However, this oxygen concentration increases the susceptibility of austenitic stainless steel to intergranular stress-corrosion cracking (IGSCC) when the other requisite factors, stress and sensitization, are present. Thus, reduction or elimination of the oxygen in BWR water may preclude cracking incidents. One approach to such a reduction of the BWR coolant oxygen concentration is to adopt alternate water chemistry (AWC) conditions using an additive(s) to suppress or reverse radiolytic oxygen formation. Several additives are available to do this but they have seen only limited and specialized application in BWR's. The objective of this program is to perform an in-depth engineering evaluation of the potential suppression additives supported by critical experiments where required to resolve substantive uncertainties. On the basis of the engineering evaluation, the optimum oxygen suppression approach will be selected and a specific BWR. plant recommended for an extended plant demonstration experiment.

The program is funded by the U. S. Department of Energy and managed by Commonwealth Research Corporation. The preliminary engineering evaluations and related test work are being done by the General Electric Co. 


\section{SUMMARY}

\subsection{MASS BALANCE FLOW SHEETS}

New data on additive concentrations have been received from independent investigators overseas. These data were analyzed with respect to possible impact on the material balance flow sheets prepared earlier in this program. 1 No revisions to the methods or results are considered to be justified.

\subsection{TURBINE BUILDING RADIATION LEVELS}

Various points in the Dresden 2 and a typical BWR/6 turbine building have been modeled to facilitate calculation of dose rates at various AWC conditions. These calculations agree reasonably well with actual measurements when compared at identical power levels or exceed them by as much as a factor of two depending on the difficulty of modeling any particular location.

\subsection{STEAM ACTIVITY}

It is expected that by using a hydrogen-addition flow. sheet, N-16 activity in the steam will increase eightfold. The $\mathrm{C}-15$ activity in the steam will not be changed significantly.

\subsection{OFF-GAS IMPURITIES}

Off-gas sampling and analysis were completed at Nine Mile Point 1. Trace impurity levels were:

\begin{tabular}{cc} 
Component & (ppm by volume) \\
\cline { 2 - 2 } $\mathrm{Kr}$ & 1.1 \\
$\mathrm{Xe}$ & $<0.2$ \\
$\mathrm{Co}$ & 1.1 \\
$\mathrm{CO}_{2}$ & 700
\end{tabular}




$\begin{array}{cc}\frac{\text { Component }}{\mathrm{CH}_{4}} & \begin{array}{c}\text { Concentration } \\ \text { (ppm by volume) }\end{array} \\ \text { Higher Hydrocarbons } & 2.8 \\ \mathrm{NO} & <0.1 \\ \mathrm{NO}_{2} & -6 \\ \mathrm{O}_{3} & <0.2 \\ & <0.03\end{array}$

\subsection{OFF-GAS SYSTEM MODIFICATIONS}

An off-gas system is proposed in which oxygen is added just upstream of the recombiner in an amount sufficient to oxidize all of the hydrogen present. The system downstream of the recombiner then operates at essentially normal flow rates and compositions. System modifications would cost an estimated $\$ 440,000$. Oxygen cost would be about $\$ 3,000 /$ month.

\subsection{CONDENSER COOLANT LEAKAGE MONITORING}

In-line specific-ion sodium and chloride monitors have been tested in the laboratory in the 0 to 5 ppb range. With only minor modifications the sodium monitor is accurate and stable enough that it is suitable for routine in-plant use. The chloride monitor is very flow sensitive and requires major improvements before it would be ready for routine, in-plant use.

\subsection{CONSTANT EXTENSION RATE TESTS}

The resistance of Type-304 stainless steel constant extension rate test (CERT) specimens to IGSCC at $288^{\circ} \mathrm{C}$ in BWR coolant was increased by reduction of dissolved oxygen concentration. Addition of $220 \mathrm{ppm}$ ammonia had no effect on failurc mcchanism, crack propagation ratc or ductility character1stics.

\subsection{STRAINING ELECTRODE TESTS}

Straining Electrode Tests (SET), using hydrogen additions to depress the specimen potential, showed that $100 \mathrm{ppb}$ added hydrogen altered the failure 
of as-welded-plus-low-temperature-sensitized Type-304 stainless steel specimens from IGSCC to ductile failure.

\subsection{DEMINERALIZER PERFORMANCE}

Because of the overwhelming adverse impact that the use of ammonia additives is predicted to have on demineralizer system performance and radwaste volume, confirming tests will be made. A test system is being assembled to actually measure both deep bed and filter-demineralizer performance at the high ammonia concentration and $\mathrm{pH}$ which are necessary for successful use of an ammonia flow sheet.

\subsection{RADWASTE SYSTEM IMPACT}

The minimum effect of the use of ammonia additives on the radwaste system is to increase radwaste volumes and required system capacity a factor of six. With cooling water leakage into the condenser, this may become as high as a 200-fold increase.

\subsection{ADDITIVE INJECTION SYSTEM}

Four different methods for injecting and dissolving hydrogen gas into reactor feedwater were studied: (a) counter-current, continuous gas-phase absorption in a packed column; (b) cocurrent, discontinuous gas-phase absorption in a packed column; (c) cocurrent absorption in a bubble column; and, (d) cocurrent absorption in a bubble column containing static mixing elements. The bubble column with the static mixers was the preferred method and will operate with a hydrogen solution efficiency of $99.95 \%$ of initial feed $(30 \mathrm{lb} / \mathrm{hr}$ ) when 14 feet of mixing units are used at final feedwater conditions. A preliminary estimate of the installed cost is $\$ 450,000$.

\subsection{EMERGENCY CORE COOLING SYSTEM AND LOSS-OF-COOLANT ACCIDENT ANALYSES}

Since there is no change in suppression-pool hydrogen or oxygen level, use of the hydrogen additive does not modify existing emergency core cooling 
system (ECCS) conditions. Increased drywell inventories of hydrogen cause less than $0.1 \%$ increase in post-loss-of-coolant accident (LOCA) drywel1 hydrogen concentrations. Hydrogen concentration does not reach the $4.0 \%$ lower explosive limit for hydrogen in air.

\subsection{RADIOACTIVITY TRANSPORT}

Data from a boiling, in-reactor loop with hydrogen addition operated by Atomic Energy of Canada Limited (AECL) show that the effects of the hydrogen-rich environment on a normal BWR system will be minimal with respect to corrosion product transport and radiation buildup.

\subsection{ADDITIVE CONSUMPTION AND SOURCE}

The use of hydrogen separating membranes and sponges is being considered as a means of recycling hydrogen thereby reducing additive cost. Technology exists for several separation schemes. 


\section{DISCUSSION}

\subsection{TASK A. 02 CONTROL - MASS BALANCE FLOW SHEETS (T. L. Wong)}

Objective. This task establishes the basic primary system flow sheets for the additives being considered. Optimum additive levels will be selected to allow a reasonable operating control range, prevent excessive and wasteful use of the chemical, and yet assure that minimum concentration requirements are always met.

Existing test information on the addition of hydrogen, ammonia and hydrazine to suppress oxygen formation has been used to predict mass balances for the GE BWR. Since the results reported in the literature cannot be applied directly because the test equipment and conditions were significantly different from those for the BWR, the results from several different tests have been used to develop methods to extrapolate the test data to BWR conditions.

\subsubsection{Additional Flow Sheet Considerations}

Mass balance flow sheets for the addition of hydrogen, ammonia, and hydrazine have been calculated and are presented in previous quarterly reports for this program. ${ }^{1,2}$ These flow sheets are still tentative and are constantly being reviewed and improved as applicable new data are discovered.

\subsubsection{Hydrogen Addition}

An unpublished Japanese paper ${ }^{3}$ describing a study on the use of hydrogen and hydrazine addition to control dissolved oxygen in the reactor water was reviewed. In che study, a hydlugen concentration of $3 \mathrm{ppm}$ at the reactor core inlet was considered necessary to reduce the oxygen concentration to one-tenth its current value (to $20 \mathrm{ppb}$ ). This is a factor of twenty higher than calculated in Reference 1 and is based solely on experimental results from the EBWR (Experimental Boiling Water Reactor). The hydrogen models already prepared for this program which are based on several different reactor tests (including the EBWR data) were not modified. 
Further support is lent to the hydrogen flow sheet presented in Reference 1 by independent Swedish studies ${ }^{4}$ in which predicted oxygen levels and corresponding hydrogen concentrations are essentially identical.

\subsubsection{Hydrazine Addition}

In terms of hydrazine addition, the Japanese study states that a hydrazine addition rate of $7 \mathrm{~kg} / \mathrm{h}(1.54 \mathrm{lb} / \mathrm{h})$ at the inlet of the recirculation line is required to reduce the oxygen concentration by a factor of approximately two. This hydrazine addition value is very low compared to Reference 1 but is based only on replacing losses due to thermal decomposition. Radiolytic decomposition is not considered. In addition, the quantity and location of the hydrazine injection are directed toward decreasing the oxygen concentration in the recirculation piping, not the entire primary system.

The thermal decomposition data referenced in the Japanese study (Figure 3-1) show that the hydrazine thermal decomposition rates are about two orders of magnitude lower than those discussed and used in Reference 1 . Based on these decomposition rates, the hydrazine addition requirements for the hydrazinecontrolling and the ammonia-controlling cases were recalculated using previously determined values for the radiolytic decomposition effects. A hydrazine addition rate of approximately $6000 \mathrm{~kg} / \mathrm{h}(13,000 \mathrm{lb} / \mathrm{h})$ was required to obtain a $25 \mathrm{ppb}$ hydrazine concentration in the core exit flow. The mass balance flow sheet for the hydrazine-controlling case at the lower thermal decomposition rate is shown in Figure 3-2. Although this value is only about $5 \%$ of that previously calculated to be necessary the amount of hydrazine required is still excessive. In the case where only enough hydrazine is required to decompose to give $10 \mathrm{ppm}$ ammonia in the core exit water, the flow sheets are identical, regardless of which thermal decomposition rate is accepted. 


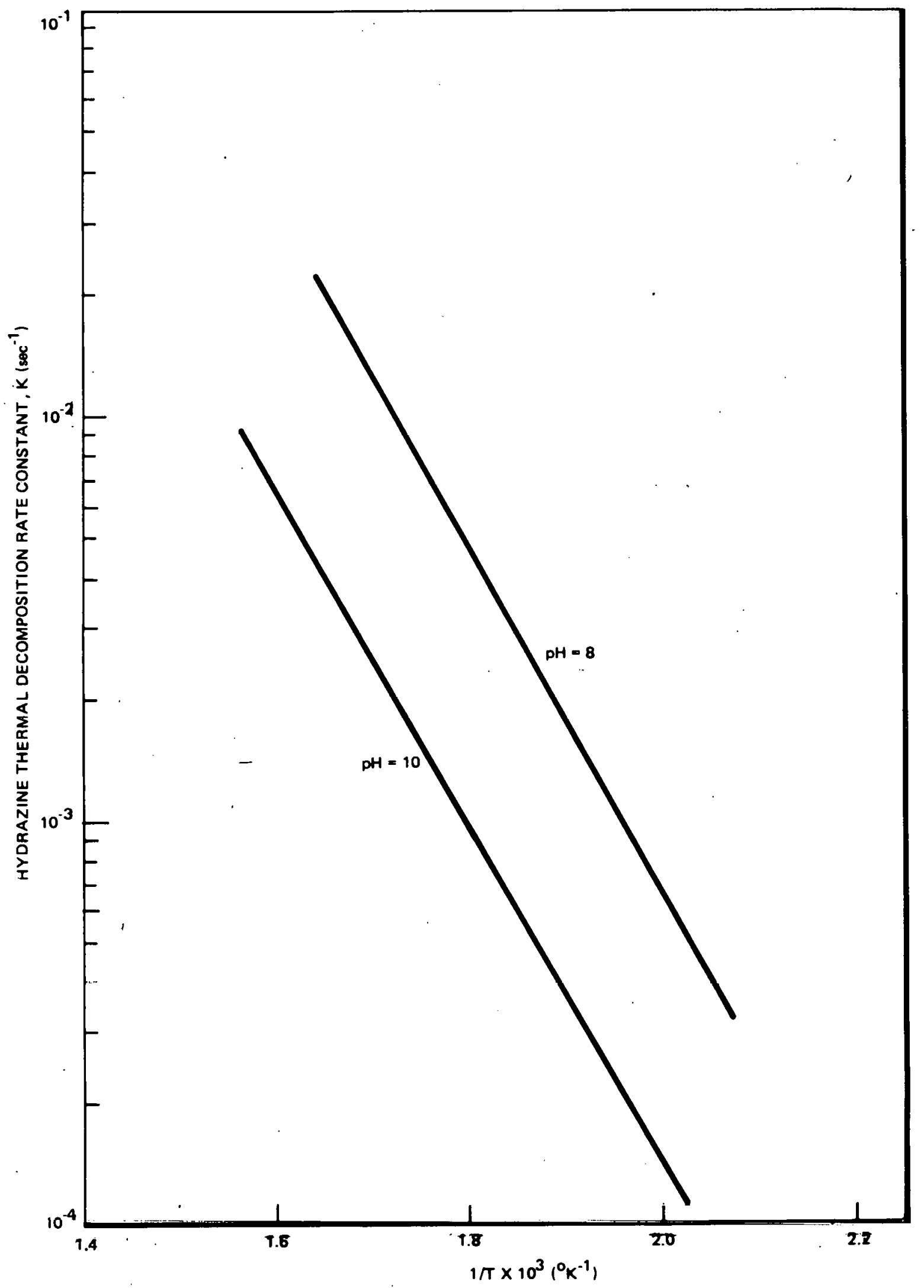

Figure 3-1. Hydrazine Decomposition Rates versus Temperature

[From: H. Hartmann, G. Resch, Mit. VGB52 54, 1958] 


$$
\begin{aligned}
& F_{1}= 4.4 \times 10^{6} \mathrm{~kg} / \mathrm{h} \\
& 19.77 \times 10^{6} \mathrm{lb} / \mathrm{h} \\
& X_{\mathrm{H}_{2}}= 40.3 \mathrm{ppm} \\
& X_{\mathrm{NH}_{3}}= 712.4 \mathrm{ppm} \\
& X_{\mathrm{N}_{2}}= 575.8 \mathrm{ppm} \\
& X_{\mathrm{N}_{2} \mathrm{H}_{4}=}=0.131 \mathrm{ppm}
\end{aligned}
$$

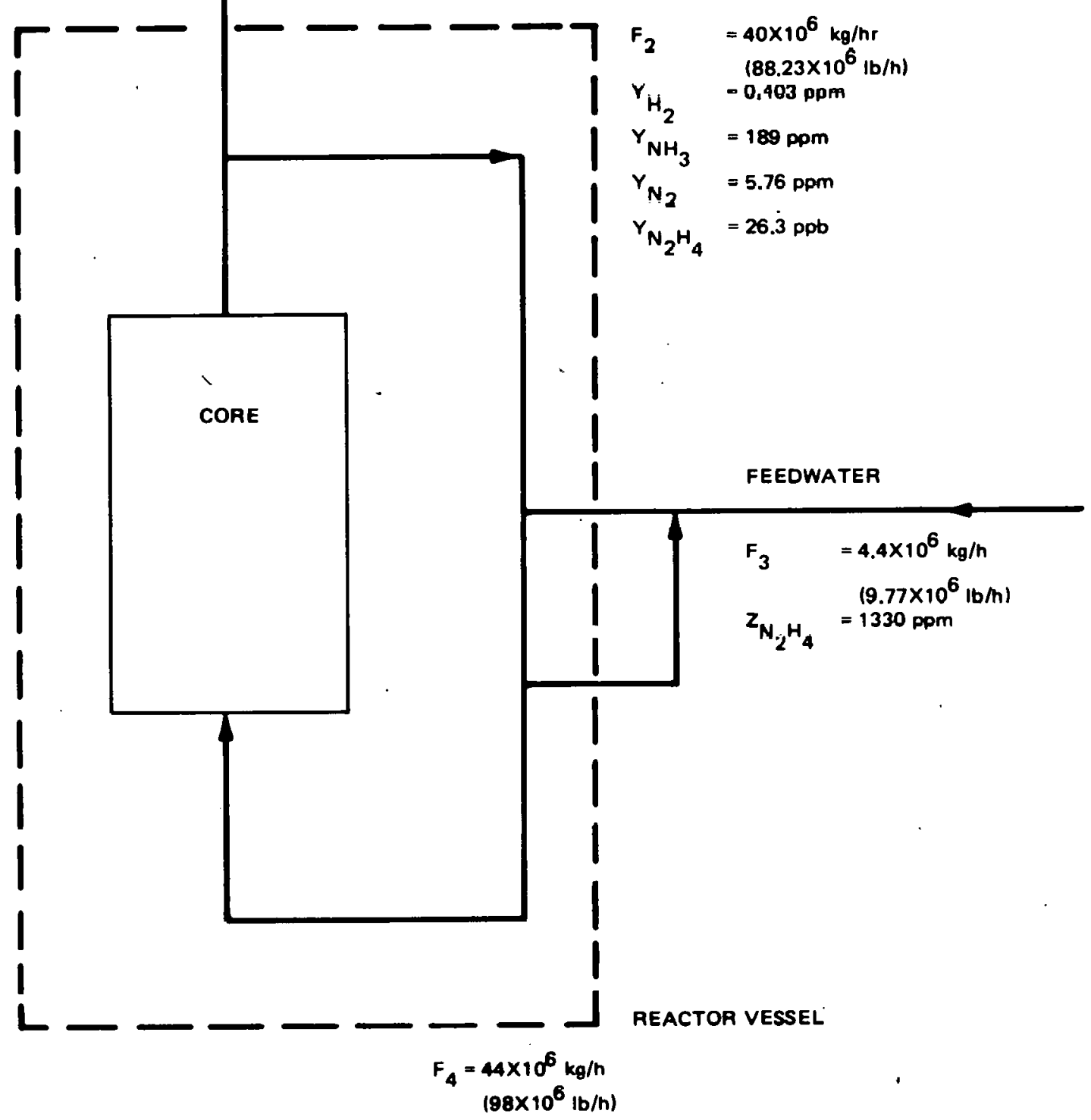

Figure 3-2. Hydrazine Addition - Hydrazine Controlling Case (Using Japanese ${ }^{3}$ thermal decomposition data) 
NEDC-23856-3

3.2 TASK B-1. N-16 DOSE RATE (H. H. Paustian, G. F. Palino)

Objective. The primary source of radioactivity in the steam from a BWR is $\mathrm{N}-16$ from the 0-16 $(n, p)$ reaction. The $N-16$ is formed in the liquid phase within the reactor core and then partitioned between the reactor water and steam during the phase separation. With standard BWR water chemistry, the bulk of the N-16 formed is quickly converted to relatively non-volatile anionic species, primarily $\mathrm{NO}_{2}^{-}$or $\mathrm{NO}_{3}^{-}$. Only a small amount of the $\mathrm{N}-16$ goes into the steam. As the oxidizing potential of the coolant is reduced by oxygen suppression additives, the proportion of the $\mathrm{N}-16$ converted to relatively volatile, cationic $\left(\mathrm{NH}_{4}{ }^{+}\right)$species markedly increases and the fraction released to the steam rises commensurately. All three potential additives, i.e., $\mathrm{H}_{2}, \mathrm{NH}_{3}$, and $\mathrm{N}_{2} \mathrm{H}_{4}$, appear to act similarly in increasing the N-16 activity in the steam; however, the exact relationships need to be verified quantitatively so that the impact on turbine building shielding and/or operator-environment dose rates can be evaluated.

\subsubsection{Dose Rate Calculations}

Models have been prepared to calculate dose rates on the turbine operating floor and in the environment surrounding the turbine building. These calculations were done for the Dresden 2 and for a typical BWR/6 arrangement. The isotopes considered were $\mathrm{N}-16$ having a $7.3 \mathrm{sec}$ half-life and $\mathrm{C}-15$ having a 2.45-sec half-life. For results to be applicable to a number of AWC's, the calculations were done assuming concentrations in the steam of $1.0 \mu \mathrm{Ci} / \mathrm{g}$ of $\mathrm{N}-16$ or $1.0 \mu \mathrm{Ci} / \mathrm{g}$ of $\mathrm{C}-15$ at the outlet of the reactor pressure vessel (RPV) nozzles. Thus, to estimate the radiation levels for a selected water chemistry, one would multiply these results by actual RPV nozzle concentrations of $\mathrm{N}-16$ and $\mathrm{C}-15$ and add them to get a total radiation level at a particular location. The results of these calculations are reported in subsequent sections.

\subsubsection{Main Steam Line Calculations for Dresden 2}

A number of steam line dose rate measurements have been made at Dresden 2 as a part of this program. These measurements are reported in Table 3-1 and Figure 3-3. 
NEDC-23856-3

Table 3-1

"C" STEAM LINE DOSE RATE MEASUREMENTS

A. Victoreen 470A Panoramic Survey Meter Measurements:

\begin{tabular}{ccc}
$\begin{array}{c}\text { Distance } \\
(\mathrm{cm})\end{array}$ & $\begin{array}{c}\text { Exposure Rate } \\
(\mathrm{R} / \mathrm{h})\end{array}$ & \multicolumn{1}{c}{ Comments } \\
\cline { 2 - 2 } 14.7 & 1.05 & Side Measurement \\
14.7 & 1.20 & Face Measurement \\
45.2 & 0.80 & Face Measurement \\
75.7 & 0.64 & Face Measurement \\
106.2 & 0.57 & Face Measurement
\end{tabular}

B. Lif Thermal Lumincscense Dosimeter Measurements:

\begin{tabular}{ccc}
$\begin{array}{c}\text { Distance } \\
(\mathrm{cm})\end{array}$ & $\begin{array}{c}\text { Exposure Rate } \\
(\overline{\mathrm{R}} / \mathrm{h})\end{array}$ & \multicolumn{1}{c}{ Comments } \\
9.0 & 1.19 & Side Measurement \\
9.0 & 1.31 & Face Measurement \\
24.2 & 1.03 & Face Measurement \\
54.7 & 0.67 & Facc Mcaourcment \\
100.4 & 0.49 & Face Measurement
\end{tabular}

aistance is from outer metal surface of the "C" steam line to the effective center of the detector system. 


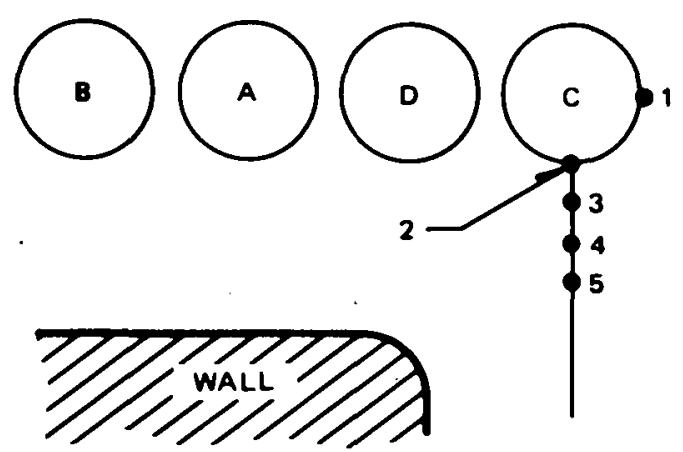

\section{A STEAMLINE SEPARATION IINSULATION EXTERIOR-TO-INSULATION EXTERIORI $=1.02 \mathrm{~m}$. INSULATION THICKNESS $\sim 9 \mathrm{~cm}$. STEAMLINES ARE 24-inch SCHEDULE 80 PIPE \\ Figure 3-3. Configuration of Steam Lines $^{a}$ (pictorial)}

This measurement program also included a $\mathrm{Ge}(\mathrm{Li})$ gamma scan of the "C" steam line at the point where the dose rate measurements were made. The radionuclides of $\mathrm{N}-16, \mathrm{C}-15$ and $0-19$ were identified in the spectra. The ratio of their concentrations in the steam was $10.6 / 5.2 / 1.0$, respectively.

The information on the ratio of isotopes and the steam line geometry, as shown in Figures 3-3 and 3-4, was used in the QAD-F computer code to calculate exposure rates based on an assumed concentration of $1.0 \mu \mathrm{Ci} / \mathrm{g}$ of $\mathrm{N}-16$ in the steam at the measurement location. By then determining the ratio of the measured exposures rates to the QAD-F calculated exposure rates, the actual N-16 and C-15 concentrations could be determined. The contribution from each line and the total QAD-F exposure rates are shown in Table 3-2.

Table 3-2

QAD-F CALCULATED EXPOSURE RATES

\begin{tabular}{|c|c|c|c|c|c|}
\hline $\begin{array}{c}\text { Detector } \\
\text { No. } \\
\end{array}$ & $\begin{array}{l}\text { Contribution } \\
\text { From Line C } \\
(\mathrm{mR} / \mathrm{hr}) \\
\end{array}$ & $\begin{array}{c}\text { Contribution } \\
\text { From Line D } \\
(\mathrm{mR} / \mathrm{hr}) \\
\end{array}$ & $\begin{array}{l}\text { Contribution } \\
\text { From Line A } \\
\quad(\mathrm{mR} / \mathrm{hr})\end{array}$ & $\begin{array}{l}\text { Contribution } \\
\text { From Line B } \\
(\mathrm{mR} / \mathrm{hr}) \\
\end{array}$ & $\begin{array}{l}\text { Total } \\
(\mathrm{mR} / \mathrm{hr})\end{array}$ \\
\hline 1 & 42.7 & 1.57 & 1.185 & - & 44.5 \\
\hline 2 & 42.7 & 7.77 & 0.788 & - & 51.3 \\
\hline 3 & 23.7 & 7.27 & 2.51 & 0.665 & 34.1 \\
\hline 4 & 15.9 & 6.65 & 2.95 & 1.13 & 26.6 \\
\hline 5 & 11.6 & 6.00 & 2.84 & 1.53 & 22.0 \\
\hline
\end{tabular}

These correspond to the measurement locations of the Victoreen $470 \mathrm{~V}$ Panoramic Survey Meter per Figure 3-3. 


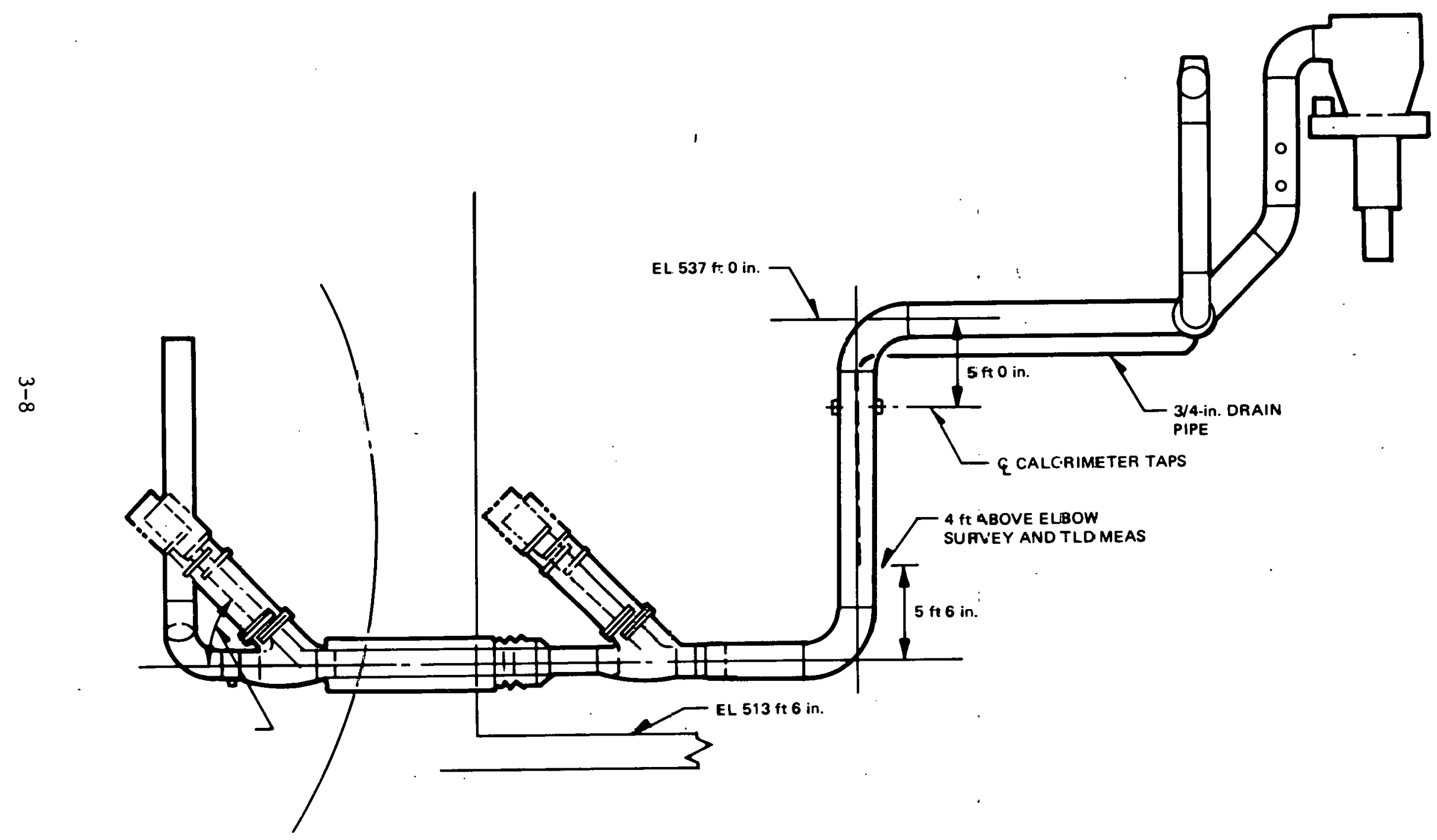

Figure 3-4. Dresden 2 Stean Line Geometry 
Table 3-3 shows the ratio of measured exposure rates to calculated exposure rates.

The average ratio was 24.1. Because results from the first three locations are somewhat more accurate, a value of 23.5 was selected. This means that at the measurement location, the $\mathrm{N}-16$ concentration in the steam was $23.5 \mu \mathrm{Ci} / \mathrm{g}$ and the $\mathrm{C}-15$ concentration was $(5.2 / 10.6)(23.5 \mu \mathrm{Ci} / \mathrm{g})=11.5 \mu \mathrm{Ci} / \mathrm{g}$. A check of this value was made using the third measurement for the LiF Thermal Luminescense Dosimeter (TLD) data. In this case, a measured-to-calculated ratio of 22.6 was obtained. This information is useful for base line data in understanding $\mathrm{N}-16 / \mathrm{C}-15$ behavior in a BWR power plant. The measured-tocalculated ratio for the several detector locations showed quite good consistency, thereby giving added confidence in its validity.

\subsubsection{Turbine Operating Floor Dose Rates at Dresden 2}

The Dresden 2 turbine operating floor arrangement is shown in Figure 3-5. It is a relatively simple arrangement with only the following turbine equipment above the floor containing significant inventories of $\mathrm{N}-16$ or $\mathrm{C}-15$ : (a) the high pressure turbine; (b) the three low pressure turbines; (c) the six combined intermediate valves (CIV's); (d) the piping located above the floor entering the CIV's and going from the CIV's to the low pressure turbines; and (e) portions of two of the four main steam lines that rise above the operating floor before entering the high pressure turbine.

Table $3 \cdot 3$

RATIO OF MEASURED EXPOSURE RATES TO QAD-F CALCULATED EXPOSURE RATES

\begin{tabular}{cccc}
$\begin{array}{c}\text { Detector } \\
\text { No. }\end{array}$ & $\begin{array}{c}\text { Measured Exposure } \\
\text { Rate }(\mathrm{mR} / \mathrm{hr})\end{array}$ & $\begin{array}{c}\text { QAD-F Exposure } \\
\text { Rate }(\mathrm{mR} / \mathrm{hr})\end{array}$ & Ratio \\
\cline { 2 - 3 } 1 & 1050 & 44.5 & 23.6 \\
2 & 1200 & 51.3 & 23.4 \\
3 & 800 & 34.1 & 23.5 \\
4 & 640 & 26.6 & 24.1 \\
5 & 570 & 22.0 & 25.9
\end{tabular}




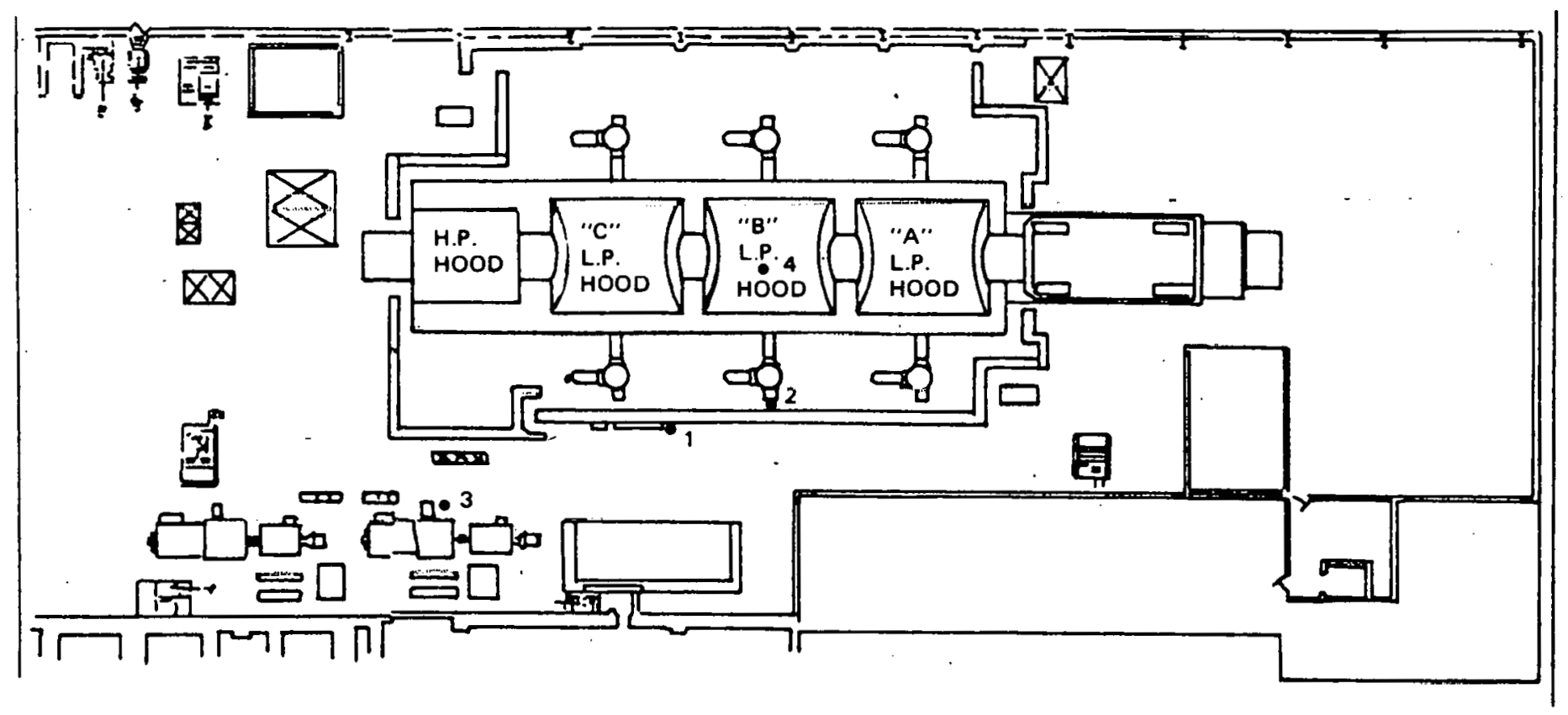

\footnotetext{
DETECTOR 1. - QUTSIDE SHIE LDING, NIRECTLY OPPOSITE CIV.4, $4 \mathrm{ft}$ ABOVE FI, COR DETECTOR 2 - INSIDE SHIELDING, DIRECTLY OPPOSITE CIV.5, $4 \mathrm{ft}$ ABOVE FLOOR DETECTOR 3 - NEAR M-G SET, 4 ft ABOVE FLOOR DETECTOR 4 - DIRECTLY ABOVE CENTER OF LP HOOD “B”, $4 \mathrm{ft}$ ABOVE ROOF OF TURBINE BUILDING
}

Figure 3-5. Dresden 2 Turbine Operating F1oor 
To calculate the inventory of either $\mathrm{N}-16$ or $\mathrm{C}-15$ in the above components, the mass inventory of steam or water in the component must be known, the mass flow rate through the component must be known, and the "age" (time since it left the RPV nozzle) of the entering steam must be known. The inventory of the isotope is then calculated from:

$$
A=a_{0} \dot{M} e^{-\lambda t} \text { in }\left(1-e^{-\lambda \Delta t}\right) / \lambda
$$

where

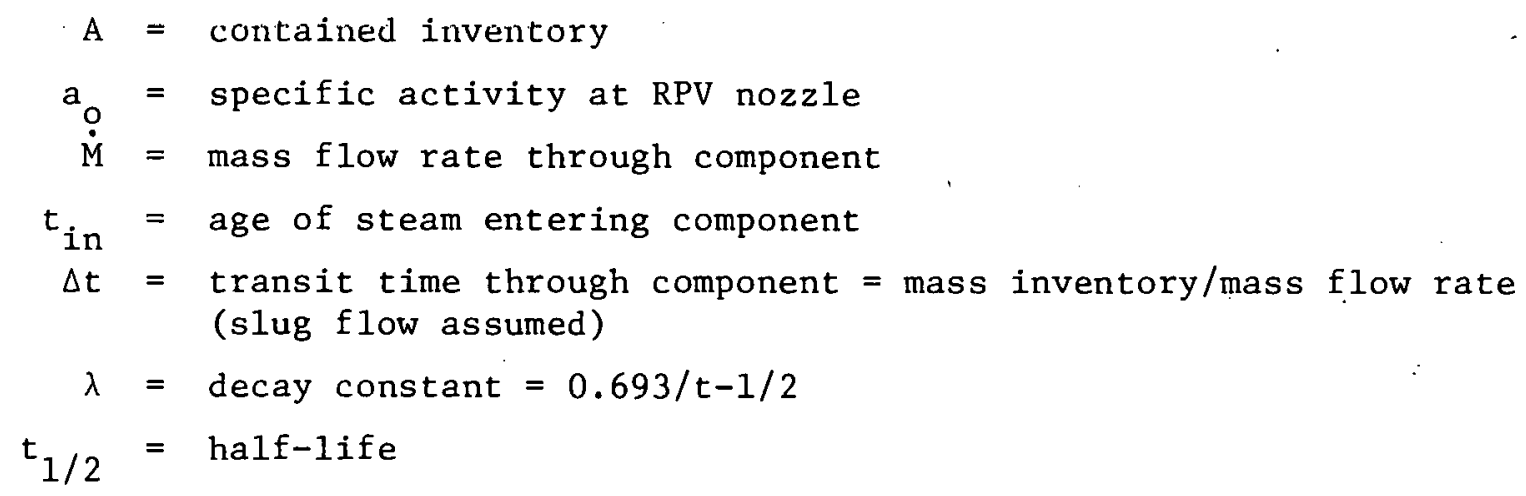

Now even though only inventories above the operating floor are of interest, the mass inventories of all components between the RPV nozzle and the turbine must be estimated to calculate the age of the steam entering the components on the floor. Thus, the mass of steam in the main steam line between the reactor and the turbine and the mass in the moisture separators must be estimated to calculate the time delay through each. Table 3-4 shows the mass inventories, mass flow rates, and age of entering steam for the turbine components on the floor, all at full power conditions. These values will change for lower power levels.

Table 3-5 then shows the contained inventories calculated for each component based on $1.0 \mu \mathrm{Ci} / \mathrm{g}$ of either $\mathrm{N}-16$ or $\mathrm{C}-15$ at the RPV nozzle. These were calculated with time-share routines which are based on Equation (3-1). 
Table 3-4

MASS FLOW CONDITIONS IN TURBINE COMPONENTS ON DRESDEN 2 OPERATING FLOOR AT 100\% POWER

\section{Component}

$11.6 \mathrm{~m}$ of 20-in. o.d. steam line entering high pressure turbine

High pressure turbine Intermediate piping (36-in o.d.):

$$
\text { Upstream of CIV's }-18.2 \mathrm{~m}
$$$$
\text { Downstream of CIV's }-31.7 \mathrm{~m}
$$

CIVs

Low pressure turbines

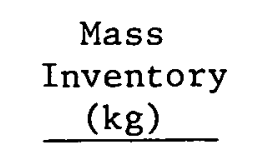

65

205

90

157

147

431

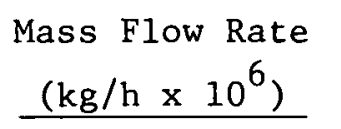

4.42

4.42

3.93

3.93

3.93

3.93
Age of Entering Steam (sec)

\section{7}

1.8

5.4

5.6

5.5

5.7

Table 3-5

CONTAINED INVENTORIES IN D-2 TURBINE EQUIPMENT

(BASED ON $1.0 \mu \mathrm{Ci} / \mathrm{g}$ of $\mathrm{N}-16$ OR OF C-15 AT RPV NOZZLE)

\section{Component}

$11.6 \mathrm{~m}$ of $20-i n$. 0.d. steam line

High pressure turbine

Intermediate piping (36-in. 1.d.):

Upstream of CIV's - $18.2 \mathrm{~m}$

Downstream of CIV's - $31.7 \mathrm{~m}$

CIV's

Low pressure turbines

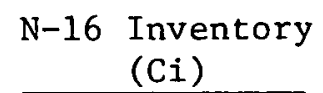

0.0548

0.172

0.0538

0.0915

0.0871

0.245

0.704
C-15 Inventory

(Ci)

0.0394

0.121

0.0315

0.0308

0.0804

0.323 
The difference between the $\mathrm{N}-16$ inventories and the $\mathrm{C}-15$ inventories is caused by the $\mathrm{C}-15^{\prime} \mathrm{s}$ more rapid decay. The inventories listed in Table 3-5 were the basis for calculating both the operating floor dose rates as well as the air-scattered dose rates to receivers outside the Dresden 2 turbine building.

To calculate operating floor dose rates, the QAD-F computer code was again utilized. Three detector locations on the operating floor and one detector on the roof were selected. Models of each of the turbine components in Table 3-5 were set up in the QAD-F geometry and dose rates calculated based on the inventories shown. Figure 3-5 shows the three detector locations on the floor and the fourth detector on the roof directly above the center of low pressure turbine hood "B". Note that one would expect Detector 2 to be one of the highest locations inside the shield wall without being in direct contact with any of the components, while Detectors 1 and 4 would be expected to be representative of comparatively high readings outside the shield walls. All detectors were $1.3 \mathrm{~m}$ above the floor or roof, respectively. Tables 3-6 and 3-7 show the dose rate contribution from each component at the selected detector locations with everything still based on $1.0 \mu \mathrm{Ci} / \mathrm{g}$ of either $\mathrm{N}-16$ or $\mathrm{C}-15$ at the RPV nozzle.

Note that the contributions from CIV's 1, 2, and 3 and associated piping to the dose rates at Detectors 1, 2, and 3 were neglected because the 1ine-ofsight between these sources and those detectors is heavily shielded by the turbine itself. Their contribution to the dose rate at Detector 4, however, is accounted for. Because CIV's 1, 2, and 3 and CIV's 4, 5, and 6 are symetric with respect to Detector 4 , the contributions from the CIV's on either side of the turbine are the same for that detector location. The inventory in the steam lines entering the high pressure turbine was treated conservatively by assuming it all to be in the pipe on the same side of the turbine as the detector position. The information in Tables 3-6 and 3-7 may be used to estimate what dose rates on the operating floor of Dresden 2 would be for any given $\mathrm{N}-16$ and $\mathrm{C}-15$ concentrations at the RPV nozzle. 
Table 3-6

N-16 OPERATING FLOOR DOSE RATES

(FOR $1 \mu \mathrm{Ci} \mathrm{N}-16 \mathrm{Gm}$ STEAM)

\section{Component} steam line

High pressure turbine

DIV-4 and piping

CIV-5 and piping

$\mathrm{CIV}-\mathrm{G}$ and piping

Low pressure turbine " $\mathrm{A}$ "

Low pressure turbine " $B$ "

Low pressure turbine " $\mathrm{C}$ "

Total
$11.6 \mathrm{~m}$ of $20-$ in. 1.d.

\begin{tabular}{|c|c|c|c|}
\hline $\begin{array}{c}\text { Detector } 1 \\
(\mathrm{mR} / \mathrm{hr})\end{array}$ & $\begin{array}{c}\text { Detector } 2 \\
(\mathrm{mR} / \mathrm{hr})\end{array}$ & $\begin{array}{c}\text { Detector } 3 \\
(\mathrm{mR} / \mathrm{hr})\end{array}$ & $\begin{array}{c}\text { Detector } 4 \\
(\mathrm{mR} / \mathrm{hr})\end{array}$ \\
\hline $1.16-4^{a}$ & $8.15-2$ & $4 \cdot 29-3$ & $5.19-2$ \\
\hline $2.04-4$ & $2.83-2$ & $8.98-4$ & $9.20-3$ \\
\hline $4.52-2$ & $2.99-1$ & $6.16-4$ & $7.35-2$ \\
\hline $3.73-5$ & $6.33+0$ & $1.61-5$ & 1.151 \\
\hline $3.50-0$ & $2.63-1$ & $4.57-7^{-}$ & $7.35-2$ \\
\hline $1.74-3$ & $2.48-2$ & $1.31-4$ & $3.26-2$ \\
\hline $1.32-4$ & $1.11-1$ & $1.79-5$ & $6.21-2$ \\
\hline $6.42-6$ & $2.48-2$ & $2.16-6$ & $3.26-2$ \\
\hline $4.74-2$ & $7.16+0$ & $5.97-3$ & $4.50-1$ \\
\hline
\end{tabular}

$a_{\text {Note }} 1.16-4=1.16 \times 10^{-4}$

$$
\frac{\left(\begin{array}{c}
+2.62-1 \\
\text { for CIV }-1,2,3
\end{array}\right)}{7.12-1}
$$


- Table 3-7

\section{C-15 OPERATING FLOOR DOSE RATES \\ (FOR $1 \mu \mathrm{Ci} \mathrm{C}-15 / \mathrm{Gm}$ STEAM)}

\begin{tabular}{|c|c|c|c|c|}
\hline Component & $\begin{array}{l}\begin{array}{c}\text { Detector } 1 \\
(\mathrm{mR} / \mathrm{hr})\end{array} \\
\end{array}$ & $\begin{array}{l}\text { Detector } 2 \\
(\mathrm{mR} / \mathrm{hr}) \\
\end{array}$ & $\begin{array}{l}\text { Detector } 3 \\
(\mathrm{mR} / \mathrm{hr}) \\
\end{array}$ & $\begin{array}{r}\text { Detector } \\
(\mathrm{mR} / \mathrm{hr}) \\
\end{array}$ \\
\hline $\begin{array}{l}11.6 \mathrm{~m} \text { of } 20-i n .0 . d . \\
\text { steam line }\end{array}$ & $4 \cdot 86-5^{a}$ & $4.78-2$ & $2.17-3$ & $3.04-2$ \\
\hline High pressure turbine & $9.04-5$ & $1.62-2$ & $4.28-4$ & $5.24-3$ \\
\hline CIV-4 and piping & $1.09-2$ & $8 \cdot 52-2$ & $1.41-4$ & $2.10-2$ \\
\hline CIV-5 and piping & $7.54-6$ & $1.83+0$ & $3.20-6$ & $3.29-2$ \\
\hline CIV-6 and piping & $5.45-9$ & $1.15-1$ & $7.92-8$ & $2.10-2$ \\
\hline Low pressure turbine " $\mathrm{A}$ " & $9.97-4$ & $9 \cdot 50-3$ & $5.04-5$ & $1.96-2$ \\
\hline Low pressure turbine "B" & $5.84-5$ & $7.74-2$ & $3.52-6$ & $4 \cdot 37-2$ \\
\hline Low pressure turbine "C" & $9.63-7$ & $9.50-3$ & $3.26-7$ & $1.96-2$ \\
\hline Total & $1.21-2$ & $2.19+0$ & $2.80-3$ & 1. . 9.3-1 \\
\hline${ }^{a}$ Note $4.86-5=4.86 \times 10^{-5}$ & & & + & $\begin{array}{l}.49-2 \\
\text { CIV-1,2, }\end{array}$ \\
\hline
\end{tabular}




\subsubsection{Environmental Gamma Radiation Levels, at Dresden 2}

A large number of sources contribute to the environmental gamma radiation levels on the Dresden site. In addition to inventories on the turbine operating floor of both Dresden 2 and Dresden 3, there are contributions from waste and surge tanks located outside the plant building, contributions from natural background (both terrestrial and cosmic) and fallout, and a contribution from the Dresden 1 turbine, which has no shielding surrounding it. The contribution from the Dresden 1 turbine is the major portion of current site gamma radiation levels. ${ }^{l}$ Thus, there would have to be a quite significant increase in N-16 and C-15 concentrations at Dresden 2 before the total site gamma radiation levels would be substantially changed.

This section reports on calculations done to estimate the contribution to the total gamma radiation level from the inventories in turbine equipment above the operating floor for Dresden 2 at a large number of detector locations in several directions about the Dresden 2 turbine building. Only airscattering was considered; building-scattered and direct line-of-sight contri- butions from Dresden 2 should be negligible. The starting point for the air-scattering calculation is the contained inventories in Table 3-5. These contained inventories are then each multiplied by a self-shielding factor to obtain equivalent point sources. The self-shielding factors are a measure of how much shielding is provided by the very material making up the turbine component containing the inventory of interest and are derived from data in appropriate QAD-F runs. Self-shielding factors for the turbine components modeled here are taken from Reference 5. The same self-shielding factors are used for $\mathrm{N}-16$ and $\mathrm{C}-15$ inventories. Table 3-8 shows the self-shielding factors used and the resulting equivalent point source strengths. Note that the equivalent point sources are considered to be isotopic. Self-shielding actually is a strong function of the anglc at which the source to detector ray emerges from the turbine component. For this calculation, self-shielding factors are generally conservatively selected for a direction or angle having the least amount of self-shielding by the actual turbine component itself. For example, this might be a direction ray perpendicular to the high pressure turbine axis. 
The computerized data-handling procedure SKREEN $^{5}$ was used to calculate estimated air-scatter dose rates for the equivalent point sources shown in Table 3-8. Table 3-9 shows the coordinates of the detector positions selected, where the $X$ axis is coincident with the turbine-generator axis and the $Y$ axis is perpendicular to it and an extension of the common wall of units 2 and 3 . Table 3-10 lists the N-16 and C-15 air-scatter dose rates at each detector location. All of the values are still normalized to unit activities of $\mathrm{N}-16$ and $\mathrm{C}-15$ at the RPV nozzle.

Table 3-8

EQUIVALENT POINT SOURCES FOR D-2 AIR-SCATTERING CALCULATION (BASED ON UNIT STEAM ACTIVITIES)

\section{Component}

$11.6 \mathrm{~m}$ of 20 -in o.d. steam line $(2.6 \mathrm{~cm}$ wall)

High pressure turbine

Intermediate piping: (1.27 cm wa11)

Downstream of CIV's $-31.7 \mathrm{~m}$ $(1.27 \mathrm{~cm}$ wall)

CIV's

Low pressure turbines

$\begin{array}{ccc}\begin{array}{c}\text { Self- } \\ \text { Faclding } \\ \text { Factor }\end{array} & \begin{array}{c}\text { N-16 Equivalent } \\ \text { Point Source } \\ \text { Inventory (Ci) }\end{array} & \begin{array}{c}\text { C-15 Equivalent } \\ \text { Point Source } \\ \text { Inventory (Ci) }\end{array} \\ 0.45 & 0.0247 & 0.0177\end{array}$

0.042

0.00722

0.00508

0.661

0.0356

0.0128
0.661
0.0605
0.0208

0.237

0.0206

0.00730

0.052

0.0127

0.00418

0.0679 
Table 3-9

\section{DETECTOR LOCATIONS FOR DRESDEN 2 AIR-SCATTER CALCULATION \\ (BASED ON UNIT STEAM ACTIVITIES)}

\begin{tabular}{|c|c|c|c|}
\hline Detector & $\mathrm{x}, \mathrm{m}$ & $-y, m$ & Description \\
\hline 1 & 152 & 43 & $152 \mathrm{~m}$ North of Dresden 2 LPT "B" \\
\hline 2 & 305 & & $305 \mathrm{~m}$ North of Dresden 2 LPT "B" \\
\hline 3 & 457 & & $457 \mathrm{~m}$ North of Dresden 2. LPT "B" \\
\hline 4 & 609 & & $609 \mathrm{~m}$ North of Dresden 2 LPT "B" \\
\hline 5 & 762 & & $762 \mathrm{~m}$ North of Dresden 2 LPT " $\mathrm{B}$ " \\
\hline 6 & 914 & & $914 \mathrm{~m}$ North of Dresden $2 \mathrm{LPT}$ "B" \\
\hline 7 & 1067 & $\downarrow$ & $1067 \mathrm{~m}$ North of Dresden $2 \mathrm{LPT}$ "B" \\
\hline 8 & 0 & 152 & $152 \mathrm{~m}$ West of Dresden 2 \\
\hline 9 & 0 & 305 & $30 \overline{5} \mathrm{~m}$ \\
\hline 10 & 0 & 457 & $457 \mathrm{~m}$ \\
\hline 11 & 0 & 609 & 609 \\
\hline 1.2 & 0 & 762 & 762 \\
\hline 13 & 0 & 914 & 914 \\
\hline 14 & 0 & 1067 & 1067 \\
\hline 15 & -52 & 86 & Southwest conner of Administration Building \\
\hline 16 & -90 & 90 & Northwest corner of Visitors Center \\
\hline 17 & -133 & 67 & Parking Lot "Center" \\
\hline 18 & 67 & 58 & Suulh curner of $2 / 3 \mathrm{Crib}$ House \\
\hline 19 & 145 & 39 & Southeast corner of $34 \mathrm{Kv}$ Relay House \\
\hline
\end{tabular}


Table 3-10

AIR-SCATTER EXPOSURE RATES FROM DRESDEN 2 TURBINE COMPONENTS ABOVE TURBINE OPERATING FLOOR (BASED ON UNIT STEAM ACTIVITIES)

\begin{tabular}{|c|c|c|c|}
\hline Detector & Location & $\begin{array}{c}\text { N-16 Air-Scatter } \\
\text { Exposure Rate } \\
(\mathrm{mR} / \mathrm{yr}) \\
\end{array}$ & $\begin{array}{c}\text { C-15 Air-Scatter } \\
\text { Exposure Rate } \\
(\mathrm{mR} / \mathrm{yr}) \\
\end{array}$ \\
\hline 1 & $152 \mathrm{~m}$ north & $2.902+0 *$ & $9.565-1$ \\
\hline 2 & $305 \mathrm{~m}$ north & $9.455-1$ & $3.046-1$ \\
\hline 3 & $457 \cdot m$ north & $2.961-1$ & $9.294-2$ \\
\hline 4 & $609 \mathrm{~m}$ north & $1.112-1$ & $3.466-2$ \\
\hline 5 & $762 \mathrm{~m}$ north & $5.090-2$ & $1.569-2$ \\
\hline 6 & $914 \mathrm{~m}$ north & $2.403-2$ & $7.369-3$ \\
\hline 7 & $1067 \mathrm{~m}$ north & $1.292-2$ & $3.941-3$ \\
\hline 8 & $152 \mathrm{~m}$ west & $1.794+0$ & $5.840-1$ \\
\hline 9 & $305 \mathrm{~m}$ west & $5.903-1$ & $1.878-1$ \\
\hline 10 & $457 \mathrm{~m}$ west & $1.903-1$ & $6.023-2$ \\
\hline 11 & $609 \mathrm{~m}$ west & $7.958-2$ & $2.504-2$ \\
\hline 12 & $762 \mathrm{~m}$ west & $3.655-2$ & $1.138-2$ \\
\hline 13 & $914 \mathrm{~m}$ west & $1.829-2$ & $5.635-3$ \\
\hline 14 & $1067 \mathrm{~m}$ west & $9.431-3$ & $2.893-3$ \\
\hline 15 & Admin. Building & $6.982+0$ & $2.402+0$ \\
\hline 16 & Visitor's center & $3.960+0$ & $1.390+0$ \\
\hline 17 & Parking lot center & $2.557+0$ & $9.118-1$ \\
\hline 18 & $2 / 3$ crib house & $9.325+0$ & $3.082+0$ \\
\hline 19 & $34 \mathrm{Kv}$ relay house & $3.104+0$ & $1.027+0$ \\
\hline
\end{tabular}




\subsubsection{Operating Floor Dose Rate Calcuations for Typical BWR/6 Arrangement}

These calculations were carried out in a very similar fashion to those done for Dresden 2 with the following exceptions:

a. The BWR/6 turbine operating floor arrangement was considered to have four moisture separator-reheaters (MSR's) located on the operating floor.

b. Experience gained from the Dresten ? calculations indicated that for mnst hetertar lorstions on the oporating floor, the nearest (or largest) sources were the major contributors to the total dose rate. This effect will be even otrongcr for the BWR/G operatiug floor arrangement that was used. Thus, dose rates near the "hottest" components (with shielding included where appropriate) were calculated individually for each important component. Past experience with measurements at operating plants was also drawn upon in deciding what sources to consider in doing these calculations.

c. The presence of MSR's on the operating floor means there also is crossover piping from the MSR's to the CIV's. This crossover piping, plus the MSR's themselves, are the major contributors to the air-scattered dose rates outside the turbine building.

Figure 3-6 shows the modified turbine operating floor arrangement used for these BWR/6 calculations. The original arrangement from the $C$. F. Braun standard SAR was modified by shortening the original two MSR's and adding an additional two MSR's for a total of four. Crossover piping for the second pair of MSR's was also added. The MSR's were considered to each have an active length of $16 \mathrm{~m}$. Only the turbine components on the operating $t$ loor shown in Figure 3-6 were considered. The air-scattering calculation was done both with and without shielding lid slabs over the MSR's and crossover piping. Also, for the air-scattering calculation, all shielding was considered to be infinitely thick or "black." This operating floor arrangement is a good representation of what will be found at BWR/6 plants. 


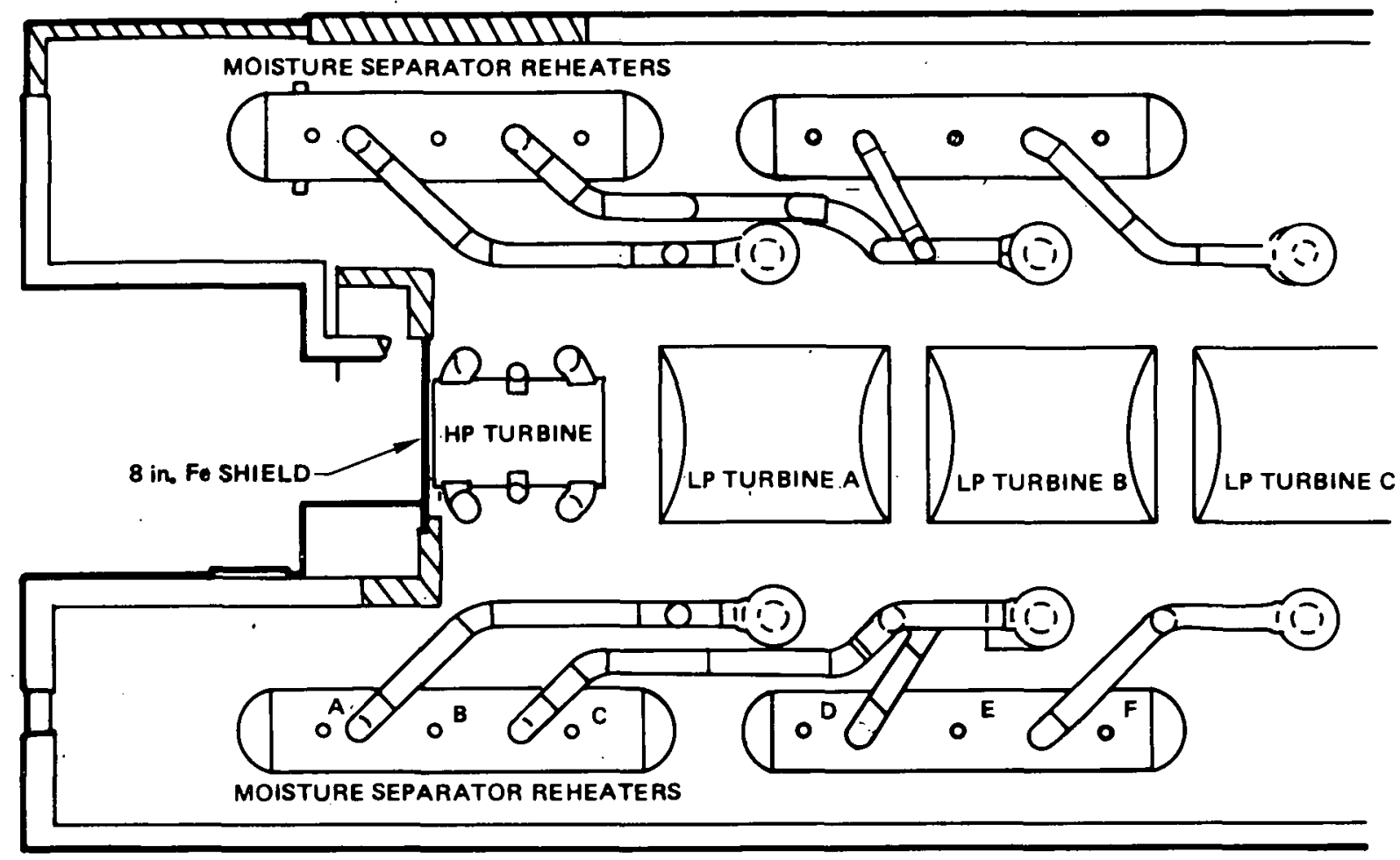

Figure 3-6. Turbine Operating Floor Arrangement For BWR/6 Calculations

Table 3-11 shows the mass flow conditions and the mass inventories in these turbine components at full power. Again, these values all vary with power level. Also note that both in Table 3-11 and in Table 3-5, the piping downstream of the CIV's is actually somewhat smaller than the upstream piping. Because of the difficulty in documenting this, however, they are both assumed to have the larger diameter. This is slightly conservative. Note also that Reference 7 was used for estimated lengths of piping beneath the operating floor and for main steam line lengths needed to calculate time delays before the steam entered the components on the operating floor. These piping lengths are not exact values from a particular plant design, but are representative for $B W R / 6$ plants.

The contained N-16 and $\mathrm{C}-15$ inventories in the BWR/6 components on the operating floor are shown in Table 3-12. These are the inventories used both in the air-scattering calculation and in the operating floor dose rate calculations. For the operating floor dose rates calculations, the highest dose rates inside the access shielding will occur in the vicinity of the high 
Table 3-11

MASS FLOW CONDITIONS IN TURBINE COMPONENTS ON BWR/6 OPERATING FLOOR AT 100\% POWER

\begin{tabular}{|c|c|c|c|}
\hline Component & $\begin{array}{c}\text { Total Mass } \\
\text { Inventory, } \\
\mathrm{kg} \\
\end{array}$ & $\begin{array}{c}\text { Mass Flow Rate } \\
\left(10^{6} \mathrm{~kg} / \mathrm{hr}\right) \\
\end{array}$ & $\begin{array}{l}\text { Age of Entering } \\
\text { Steam (sec) }\end{array}$ \\
\hline $\begin{array}{l}11 \mathrm{~m} \text { of } 28-i n . \text { o.d. } \\
\text { steam line entering } \\
\text { high pressure tur- } \\
\text { bine ( } 2 \text { lines) }\end{array}$ & 122 & 6.69 & 3.111 \\
\hline $\begin{array}{l}\text { High pressure } \\
\text { turbine }\end{array}$ & 172 & 6.69 & 3.177 \\
\hline $\begin{array}{l}20 \mathrm{~m} \text { of } 42-i n \text { o.d. } \\
\text { piping (above floor) } \\
\text { going from high pres- } \\
\text { sure turbine to MSRs } \\
\text { (4. lines) }\end{array}$ & 120 & 5.97 & 3.3 \\
\hline $\begin{array}{l}\text { MSRs } \\
\text { 1) Shell side } \\
\text { before mositure } \\
\text { separation }\end{array}$ & 1048 & 5.97 & 4.2 \\
\hline $\begin{array}{l}\text { 2) Shell side } \\
\text { after moisture } \\
\text { separation }\end{array}$ & 1425 & 4.88 & 4.8 , \\
\hline 3) Drain trough & 2722 & 1.04 & 4.7 \\
\hline $\begin{array}{l}\text { 4) } \text { First stage } \\
\text { reheater tube } \\
\text { bundle }\end{array}$ & 3902 & 0.32 & 4.3 \\
\hline $\begin{array}{l}\text { 5) Second stage } \\
\text { reheater tube } \\
\text { hundle }\end{array}$ & 4310 & 0.28 & 5.4 \\
\hline & $\overline{13 / 07}$ & & \\
\hline $\begin{array}{l}178 \mathrm{~m} \text { of } 42-i n .0 . d . \\
\text { piping from MSR's to } \\
\text { CIV's }\end{array}$ & 758 & 4.88 & 5,9 \\
\hline CIV's & 129 & 4.88 & 6.4 \\
\hline $\begin{array}{l}31 \mathrm{~m} \text { of } 42-i n \text {. o.d. } \\
\text { piping from CIV's to } \\
\text { low pressure turbines }\end{array}$ & 132 & 4.88 & 6.5 \\
\hline $\begin{array}{l}\text { Low pressure } \\
\text { turbines }\end{array}$ & 346 & 4.88 & 6.6 \\
\hline
\end{tabular}


Table 3-12

CONTAINED INVENTORIES IN BWR/ 6 TURBINE EQUIPMENT

(BASED ON $1.0 \mu \mathrm{Ci} / \mathrm{g}$ OF $\mathrm{N}-16$ OR $\mathrm{C}-15 \mathrm{AT}$ RPV NOZZLE)

\section{Component}

11 m of 28-in. o.d. steam line entering high pressure turbine (2 lines)

High pressure turbine

$20 \mathrm{~m}$ of 42-in. o.d. piping

from high pressure turbine

to MSR's (4 11nes)

MSRs

$178 \mathrm{~m}$ of 42-in. o.d. piping

from MSR's to CIV's

CIV's

$31 \mathrm{~m}$ of 42-in. o.d. piping

from CIV's to low pressure

turbine

Low pressure turbine

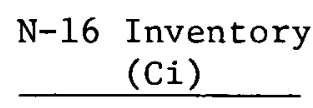

0.090

0.13

0.089

3.8

0.42

0.070

0.071

0.18

4.83
C-15 Inventory

(Ci)

0.050

0.069

0.048

1.0

0.13

0.021

0.021

0.051

1.4

pressure turbine and the MSR's. Outside the shield walls, the highest dose rate will occur at the wall surface near the midpoint of an MSR. These are the locations where dose rate calculations were done.

The first operating floor dose rate calculations done were simply for a number of detector locations near an MSR. Figure 3-7 is a simple sketch of the MSR and the detector locations and Table 3-13 shows the QAD-F results.

Note that contact dose rates on the crossover piping leaving the MSR's were calculated to be approximately $12.7 \mathrm{mR} / \mathrm{hr}$ for $\mathrm{N}-16$ and $3.27 \mathrm{mR} / \mathrm{hr}$ for $\mathrm{C}-15$. This is still based on $1.0 \mathrm{Ci} / \mathrm{g}$ of either $\mathrm{N}-16$ or $\mathrm{C}-15$ at the RPV nozzle.

Table 3-14 shows the effect of a concrete shield wall upon the dose rate of a detector lcoated at the MSR midplane $3 \mathrm{~m}$ above the floor and $30 \mathrm{~cm}$ away from the outer surface of the wall. The inner surface of the shield wall is $4.1 \mathrm{~m}$ from the center of the MSR. 


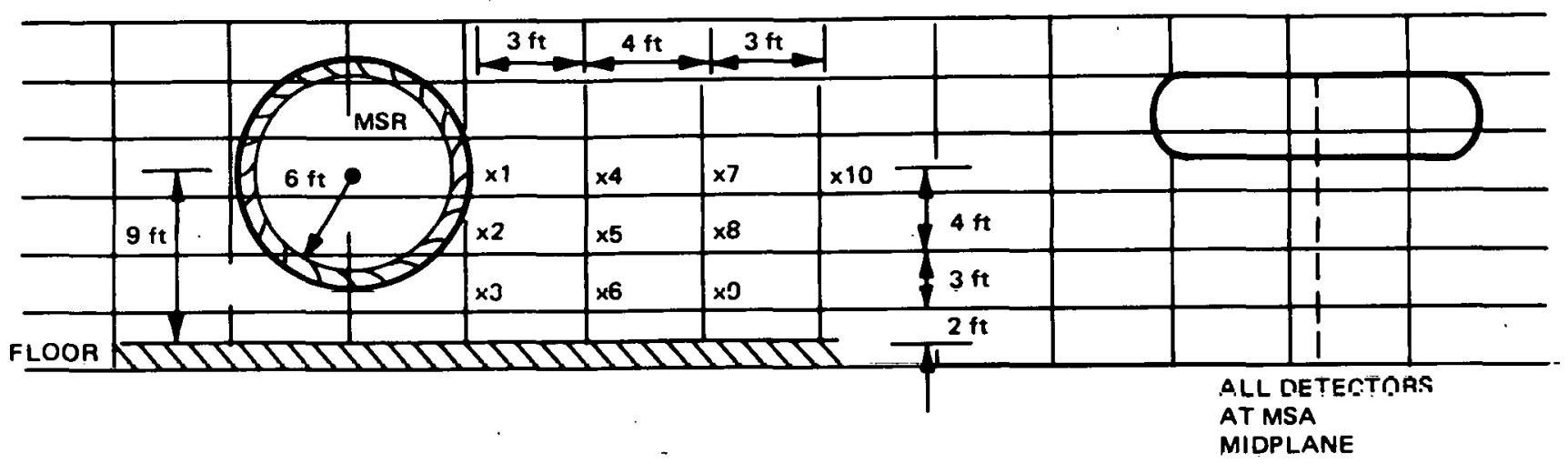

Figure 3-7. Detector Locations Near MSR

Table 3-13

QAD-F CALCULATED DOSE RATES NEAR BWR/6 MSR

\begin{tabular}{crc} 
Detector & $\mathrm{N}-16$ Dose Rate $(\mathrm{mR} / \mathrm{hr})$ & $\mathrm{C}-15$ Dose Rate $(\mathrm{mR} / \mathrm{hr})$ \\
\hline 1 & 11.03 & 2.64 \\
2 & 13.02 & 3.84 \\
3 & 10.27 & 3.00 \\
4 & 7.86 & 1.97 \\
5 & 7.79 & 2.26 \\
6 & 7.21 & 2.11 \\
7 & 5.35 & 1.39 \\
8 & 5.05 & 1.45 \\
9 & 4.95 & 1.43 \\
10 & 4.32 & 1.14
\end{tabular}


NEDC-23856-3

Table 3-14

QAD-F CALCULATED DOSE RATES ON OTHER SIDE OF SHIELD WALL ADJACENT TO AN MSR

Shield Wall

Thickness

$$
\text { N-16 Dose Rate (mR/hr) }
$$

C-15 Dose Rate (mR/hr)

$0.45 \mathrm{~m}$

0.311

0.0728

$0.61 \mathrm{~m}$

0.123

0.0278

$0.91 \mathrm{~m}$

0.0195

0.00407

$1.22 \mathrm{~m}$

0.00310

0.000595

The other major sources on the BWR/ 6 operating floor in addition to the MSR's and associated crossover piping are the high pressure turbine, the two segments of main steam line that rise above the floor before entering the turbine, and the four segments of turbine-to-MSR piping that exit the turbine above the floor, but then. drop below the operating floor to travel to the MSR's. Table 3-15 shows the QAD-F calculated dose rates for detectors $0.9 \mathrm{~m}, 1.5 \mathrm{~m}, 3.0 \mathrm{~m}$, and $6.1 \mathrm{~m}$ from the outside surface of the $20 \mathrm{~cm}$ iron shield immediately west of the high pressure turbine and for detectors $1,1.5,3$ and $6.1 \mathrm{~m}$ from the outside surface of the high pressure turbine along a line perpendicular to the turbine axis passing through the turbine center. All detectors are $1.3 \mathrm{~m}$ above the floor. Dose rates in Table 3-15 are caused only by the inventory contained in the high pressure turbine.

Table 3-15

QAD-F CALCULATED DOSE RATES NEAR THE HIGH PRESSURE TURBINE

Detector Location $\quad \underline{\mathrm{N}-16 \text { Dose Rate }(\mathrm{mR} / \mathrm{hr}) \quad \text { C-15 Dose Rate (mR/hr) }}$

$1 \mathrm{~m}$ from Fe shield

0.00918

0.00373

$1.5 \mathrm{~m}$ from Fe shield

0.00923

0.00379

$3 \mathrm{~m}$ from $\mathrm{Fe}$ shield

0.00605

0.00250

$6.1 \mathrm{~m}$ from Fe shield

0.00255

0.00106

Im on perpendicular

1.29

0.573

$1.5 \mathrm{~m}$ on perpendicular

0.852

0.378

3II ón perpendicular

0.388

0.172

$6.1 \mathrm{~m}$ on perpendicular

0.168

0.0745 
In reality, the eight detector locations in Table 3-15 will see contributions from the high pressure turbine, the piping entering and exiting the high pressure turbine, and from the nearest MSR. In this case it was conservatively assumed that the location of the MSR was shifted so that the midplane coincided with the midplane of the high pressure turbine. Figure 3-8 shows the simplified shielding geometry that was mocked up.

Tables 3-16 and 3-17 show the dose rate contributions from each source. Contributions from all other sources are considered negligible. The rather sharp increase in the MSR contribution to the dose rate in moving from Detector 7 to Detector 8 occurs beçause Detector 8 is far ennugh heynd the west end of the MSR model that there is a significant contribution through the end of the MSR instead of through the side. Self-shielding in the direction of the MSR end is less than it is for the side. Note also that the piping entering and exiting the high pressure turbine contributes more than does the high pressure turbine itself.

Table 3-16

QAD-F CALCULATED N-16 DOSE RATES FOR COMBINED SOURCES NEAR HIGH PRESSURE END OF TURBINE

\begin{tabular}{|c|c|c|c|c|c|}
\hline Detector & $\begin{array}{c}\text { H1gh Pressure } \\
\text { Turbine } \\
\text { (mR/hr) } \\
\end{array}$ & MSR (mR/hr) & $\begin{array}{l}\text { High Pressure } \\
\text { Steam Inlet } \\
\text { T.ines (mR/hr) } \\
\end{array}$ & $\begin{array}{l}\text { Turbine-to } \\
\text { MSR Piping } \\
(\mathrm{mR} / \mathrm{hr}) \\
\end{array}$ & $\begin{array}{c}\text { Total } \\
(\mathrm{mR} / \mathrm{hr})\end{array}$ \\
\hline 1 & 1. $29+n *$ & $2 . n k+n$ & $4.60+1$ & $6.18+0$ & $5.58+1$ \\
\hline 2 & $8.52-1$ & $2.31+0$ & $1.26+1$ & $6.74+0$ & 2.2 .511 \\
\hline 3 & $3.88-1$ & $3.12+0$ & $3.38+0$ & $4.92+n$ & $1.18+1$ \\
\hline 4 & $1.68-1$. & $7.14+0$ & $9.89-1$ & $1.67+0$ & $9.97+0$ \\
\hline 5 & $9.18-3$ & $1.22-3$ & $1.72-2$ & $6.88-2$ & $9.64-2$ \\
\hline 6 & $9.23-3$ & $3.51-3$ & $1.50-2$ & $5.62-2$ & $8.39-2$ \\
\hline 7 & $6.05-3$ & $4.78-3$ & $1.09-2$ & $3.51-2$ & $5.68-2$ \\
\hline 8 & $2.55-3$ & $2.42-1$ & $6.18-3$ & $1.57-2$ & $2.66-1$ \\
\hline
\end{tabular}

$* 1.29+0=1.29 \times 10^{+0}$ 
NEDC-23856-3

Table 3-17

QAD-F CALCULATED C-15 DOSE RATES FOR COMBINED SOURCES NEAR HIGH PRESSURE END OF TURBINE

\begin{tabular}{|c|c|c|c|c|c|}
\hline Detector & $\begin{array}{c}\text { High Pressure } \\
\text { Turbine } \\
(\mathrm{mR} / \mathrm{hr}) \\
\end{array}$ & $\operatorname{MSR}(\mathrm{mR} / \mathrm{hr})$ & $\begin{array}{l}\text { High Pressure } \\
\text { Steam Inlet } \\
\text { Lines (mR/hr) }\end{array}$ & $\begin{array}{l}\text { Turbine-to } \\
\text { MSR Piping } \\
(\mathrm{mR} / \mathrm{hr}) \\
\end{array}$ & $\begin{array}{c}\text { Total } \\
(\mathrm{mR} / \mathrm{hr})\end{array}$ \\
\hline 1 & $5.73-1$ & $5.84-1$ & $1.99+1$ & $2.85+0$ & $2 \cdot 39+1$ \\
\hline 2 & $3.78-1$ & $6.55-1$ & $5.72+0$ & $2.97+0$ & $9.72+0$ \\
\hline 3 & $1.72-1$ & $8.92-1$ & $1.53+0$ & $2.16+0$ & $4.75+0$ \\
\hline 4 & $7.45-2$ & $2.11+0$ & $4 \cdot 48-1$ & $7.34-1$ & $3.37+0$ \\
\hline 5 & $3.73-3$ & $2.77-4$ & $7.19-3$ & $2.87-2$ & $3.99-2$ \\
\hline 6 & $3.79-3$ & $8.49-4$ & $6 \cdot 30-3$ & $2.35-2$ & $3.44-2$ \\
\hline 7 & $2.50-3$ & $1.24-3$ & $4 \cdot 58-3$ & $1.47-2$ & $2.30-2$ \\
\hline 8 & $1.06-3$ & $6.91-2$ & $2.60-3$ & $6.61-3$ & $7.94-2$ \\
\hline
\end{tabular}

$* 1.29+0=1.29 \times 10^{+0}$

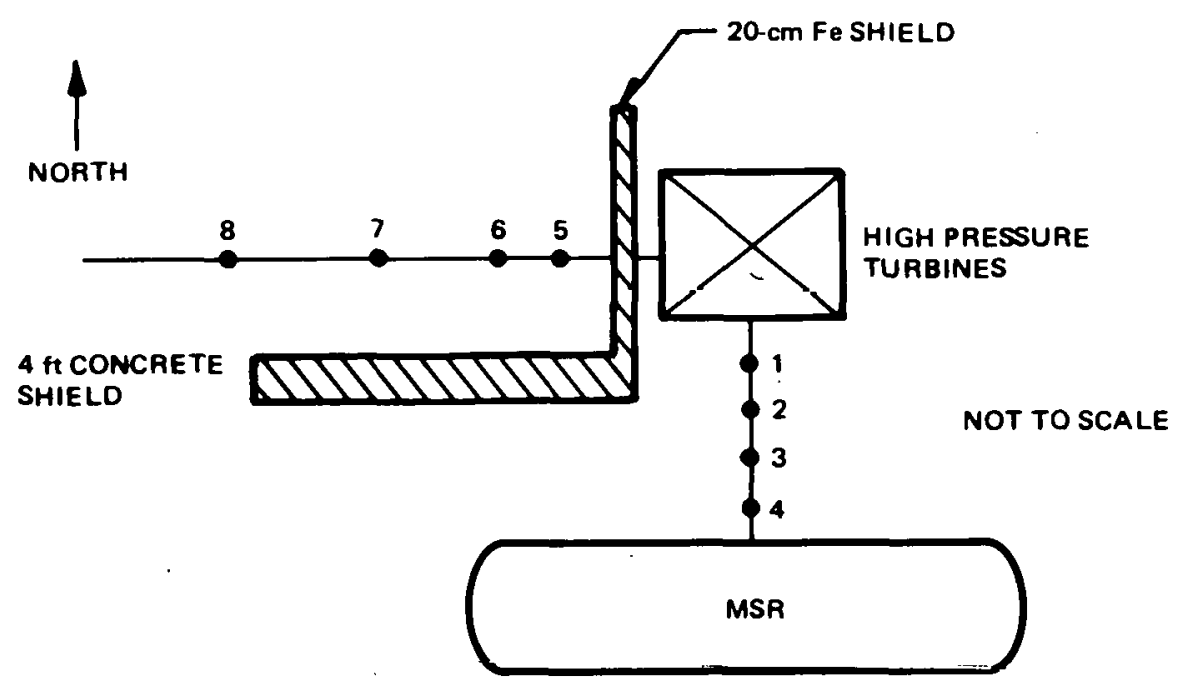

Figure 3-8. Geometry for Combined Source QAD-F Dose Rate Calculation 
NEDC-23856-3

The dose rates listed in Tables 3-16 and 3-17 are representative of those values which would be encountered in a BWR/6 turbine operating floor arrangement and may be scaled up by the appropriate RPV nozzle concentration factors to evaluate the impact of any particular AWC.

\subsubsection{Environmental Gamma Radiation Levels for a BWR/6 Plant}

This section reports on calculations done to estimate the contribution to the total environmental gamma radiation levels from the inventories in turbine equipment above the operating floor for a BWR/6 turbine operating floor arrangement. Just as was done for Dresden 2, the starting point for this air-scattering calculation was the contained inventories in the turbine equipment that are listed in Table 3-14. The contained inventories were multiplied by self-shielding factors to obtain equivalent point sources. Table 3-18 shows the self-shielding factors used and the resulting equivalent point source strengths. Reference 5 was again used for self-shielding factors. Comments on the variation of self-shielding with direction also apply to the BWR/6 arrangement.

SKREEN was again used to calculate the estimated air-scatter dose rates; the spectral information required was obtained from Reference 7 . In the casse of the BWR/6, two sets of calculations were run, one including concrete lids over the entire length of the MSR's and crossover piping (but not over the turbine itself and with no inner shield walls between the MSR's and the turbine), and one without such concrete lids. C. F. Braun's Safety Analysis Report (SAR), which was the starting point for this BWR/6 arrangement, included lids over the MSR's and crossover piping.

Table 3-19 showis the $N-16$ and $C-15$ air-scatter dose rates at each of 14 detector locations along 2 detector axes. for the arrangement with and without MSR 1ids. Note all these calculations are based on $1.0 \mu \mathrm{Ci} / \mathrm{g}$ of either $\mathrm{N}-16$ or $\mathrm{C}-15$ at the RPV nozzle.

The coordinate system origin is on the operating floor at the center of the high pressure turbine. The detector location description. "perpendicular" and "parallel" are with respect to the turbine-generator axis. The 
Table 3-18

EQUIVALENT POINT SOURCES FOR BWR/6 AIR-SCATTERING CALCULATION

\begin{tabular}{|c|c|c|c|}
\hline Component & $\begin{array}{l}\text { Self-Shielding } \\
\text { Factor } \\
\end{array}$ & $\begin{array}{l}\text { N-16 Equivalent } \\
\text { Point Source } \\
\text { Inventory (Ci) }\end{array}$ & $\begin{array}{l}\text { C-15 Equivalent } \\
\text { Point Source } \\
\text { Inventory (Ci) }\end{array}$ \\
\hline $\begin{array}{l}11 \mathrm{~m} \text { of } 28 \text {-in o.d. } \\
\text { steam line entering } \\
\text { high pressure tur- } \\
\text { bine ( } 2 \text { lines) }\end{array}$ & 0.348 & 0.0314 & 0.0174 \\
\hline $\begin{array}{l}\text { High pressure } \\
\text { turbine }\end{array}$ & 0.042 & 0.00533 & 0.00291 \\
\hline $\begin{array}{l}\text { 20m of } 42 \text {-in. o.d. } \\
\text { piping from high } \\
\text { pressure turbine to } \\
\text { MSR's ( } 4 \text { lines) }\end{array}$ & 0.600 & 0.0532 & 0.0287 \\
\hline MSR's & 0.141 & 0.533 & 0.142 \\
\hline $\begin{array}{l}178 \mathrm{~m} \text { of } 42-i n . \text { o.d. } \\
\text { piping from MSR's } \\
\text { to CIV's }\end{array}$ & 0.600 & 0.254 & 0.0800 \\
\hline CIV's & 0.237 & 0.0165 & 0.00488 \\
\hline $\begin{array}{l}31 \mathrm{~m} \text { of } 42 \text {-in. o.d. } \\
\text { piping from CIV's to } \\
\text { low pressure turbines }\end{array}$ & 0.600 & 0.0425 & 0.0124 \\
\hline \multirow[t]{2}{*}{$\begin{array}{l}\text { Low pressure } \\
\text { turbines }\end{array}$} & 0.055 & 0.0100 & 0.00282 \\
\hline & & 0.946 & 0.291 \\
\hline
\end{tabular}

Table 3-19

AIR-SCATTER EXPOSURE RATES FROM BWR/6 TURBINE COMPONENTS

(FOR STEAM ACTIVITY OF UNITY AT RPV OUTLET)

Detector

Number

$1 \quad 152 \mathrm{~m}$, perpendicular

2. $305 \mathrm{~m}$, perpendicular

$3457 \mathrm{~m}$, perpendicular

$4610 \mathrm{~m}$, perpendicular

$5 \quad 762 \mathrm{~m}$, perpendicular
N-16 Air-Scatter

Exposure Rate (mR/yr)

No MSR Lids MSR Lids
C-15 Air-Scatter

Exposure Rate (mR/yr)

No MSR Lids MSR Lids

$\begin{array}{llll}14.0 & 5.7 & 3.4 & 1.4 \\ 3.3 & 1.3 & 0.79 & 0.32 \\ 0.92 & 0.37 & 0.21 & 0.09 \\ 0.33 & 0.14 & 0.08 & 0.03 \\ 0.14 & 0.07 & 0.03 & 0.02\end{array}$


Table 3-19

AIR-SCATTER EXPOSURE RATES FROM BWR/6 TURBINE COMPONENTS (FOR STEAM ACTIVITY OF UNITY AT RPV OUTLET) (Continued)

\begin{tabular}{|c|c|c|c|c|c|c|}
\hline \multirow[t]{2}{*}{$\begin{array}{l}\text { Detector } \\
\text { Number }\end{array}$} & \multirow[t]{2}{*}{ Location } & \multicolumn{3}{|c|}{$\begin{array}{l}\text { N-16 Air-Scatter } \\
\text { Exposure Rate (mR/yr) }\end{array}$} & \multicolumn{2}{|c|}{$\begin{array}{c}\text { C-15 Air-Scatter } \\
\text { Exposure Rate (mR/yr) }\end{array}$} \\
\hline & & No & MSR Lids & MSR Lids & No MSR Lids & MSR Lids \\
\hline 6 & 914m, perpendicular & & 0.06 & 0.03 & 0.01 & 0.007 \\
\hline 7 & $1067 \mathrm{~m}$, perpendicular & & 0.03 & 0.02 & 0.008 & 0.004 \\
\hline 8 & $152 \mathrm{~m}$, parallel & & 16.0 & 6.0 & 3.7 & 1.5 \\
\hline 9 & $305 \mathrm{~m}$, paralle1 & & 4.9 & 1.8 & 1.2 & 0.48 \\
\hline 10 & $457 \mathrm{~m}$, parallel & & 1.4 & 0.47 & 0.34 & 0.13 \\
\hline 11 & $610 \mathrm{~m}$, paralle1 & & 0.50 & 0.17 & 0.12 & 0.05 \\
\hline 12 & $762 \mathrm{~m}$, parallel & & 0.22 & 0.07 & 0.03 & 0.02 \\
\hline 13 & $914 \mathrm{~m}$, parallel & & 0.10 & 0.03 & 0.02 & 0.009 \\
\hline 14 & $1067 \mathrm{~m}$, parallel & & 0.05 & 0.02 & 0.01 & 0.005 \\
\hline
\end{tabular}

perpendicular direction vector passes through the center of the high pressure turbine. The parallel direction vector is coincident on the turbinegenerator axis and passes through the high pressure turbine toward the low pressure end of the turbine-generator. This direction was selected rather than the opposite direction ray $180 \mathrm{deg}$ away from it because the reactor building situated on the high pressure end of the turbine building would cast a large "shadow" for any detectors located behind it.

\section{$3.2 .2 \quad \mathrm{~N}-16$ Activity Level}

Table 3-20 lists five studies in which $\mathrm{N}-16$ steam activity measurements were made during addition of hydrogen to the coolant of a BWR or of a test facility simulating the BWR. These tests occurred on ALPR, ${ }^{6}$ BORAX IV, ${ }^{7}$ EBWR, 8 HBWR, 9 and in a test loop at R2 in Sweden. 10 Interestingly, the results of all five measurements were quite similar in that the steam line radiation levels increased by factors in the range of 2 to 10 . It is recommended that projected dose rate calculations be based on an increase of eightfold for the proposed hydrogen addition flow sheets. 
Table $3-20$

EFFECT OF HYDROGEN ADDITION ON N-16 STEAM LINE ACTIVITY

\begin{tabular}{|c|c|c|c|c|c|c|}
\hline Reactor & $\begin{array}{c}\text { Reactor } \\
\text { Power } \\
\left(\text { MW }_{t}\right) \\
\end{array}$ & $\begin{array}{l}\text { Temperature } \\
\quad\left({ }^{\circ} \mathrm{C}\right)\end{array}$ & $\begin{array}{l}\text { Absolute } \\
\text { Pressure } \\
\text { (M P.) } \\
\end{array}$ & $\begin{array}{l}\text { N-16 Steam- } \\
\text { Water Dist. } \\
\text { Coefficient }\end{array}$ & $\begin{array}{c}\text { Steam Line } \\
\mathrm{N}-16 \text { Fractional } \\
\text { Increase } \\
\end{array}$ & $\begin{array}{c}\text { Feedwater } \\
\mathrm{H}_{2} \begin{array}{l}\text { Addition Rate } \\
(\mathrm{m} \ell S T P / \mathrm{kg})\end{array} \\
\end{array}$ \\
\hline ALPR & 2.7 & 216 & 2.17 & - & $2-6$ & $12-51$ \\
\hline BORAX IV & 4.0 & 216 & 2.17 & - & 4.3 & 42.3 \\
\hline EBWRR ${ }^{13}$ & 20.0 & 254 & 4.24 & 0.115 & - & no addition \\
\hline EBWR $^{8}$ & 20.0 & 254 & 4.24 & - & च & 40 \\
\hline EBWR $^{13}$ & (?) & - & - & $(?)$ & 10.7 & $(?)$ \\
\hline HBWR & 10.0 & - & 2.93 & $0.06^{\mathrm{b}}$ & - & no addition \\
\hline HBWR & 10.0 & - & 2.93 & $0.4^{\mathrm{b}}$ & $\sim 7$ & $>30$ \\
\hline Loop 5 at R2 & 49.0 & 277 & 6.48 & 0.2 to 0.4 . & - & no addition \\
\hline Loop 5 at R2 & 49.0 & 277 & 6.48 & 1.0 to 4.0 & $3-10$ & 0.5 to 15 \\
\hline
\end{tabular}




\subsubsection{Carbon Chemistry}

The chemical form of $\mathrm{C}-15$ (2.49s) and $\mathrm{C}-14$ (5692y) in the BWR is of interest due to the primary system radiation fields resulting from $\mathrm{C}-15$ and the long-term environmental impact of the release of $\mathrm{C}-14$. In addition, questions have arisen concerning the expected change in the $\mathrm{C}-15$ carryover upon adoption of an AWC for the BWR.

of the few fundamental studies of the reactions of hot carbon atoms in aqueous solutions that have been performed, the most extensive and detailed was made by Stenström ${ }^{11}$ whn studied the reactions of ${ }^{11} \mathrm{C}$ atoms in aqueous solutions. ${ }^{12}$ Numerous reaction products were observed and the yield of any one product was found to be dose dependent.

At low doses (160 rad) $\mathrm{CO}_{2}(23 \pm 1 \%), \mathrm{CO}(32 \pm 1 \%), \mathrm{HCO}_{2} \mathrm{H}(17 \pm 2 \%), \mathrm{H}_{2} \mathrm{CO}$ $(21 \pm 2 \%), \mathrm{CH}_{3} \mathrm{OH}(6 \pm 2 \%)$ and $\mathrm{CH}_{4}(0.2 \pm 0.03 \%)$ are the observed reaction products. At the higher doses ( $>14000 \mathrm{rad}$ ) the principal product is $\mathrm{CO}_{2}$. The dose rate in the Dresden 2 core during operation has been estimated to be $26.6 \times 10^{4} \mathrm{rad} / \mathrm{sec}$ (neutron + gamma), 14 and since the in-channel transit time is on the order of 1 second, doses considerably in excess of 14000 rads are expected and ${ }^{15} \mathrm{CO}_{2}$ (or ${ }^{14} \mathrm{CO}_{2}$ ) should be the principal reaction product released from the core of the BWR.

This prediction is supported by the measurements of Kunz, et al., of the chemical form of $\mathrm{C}-14$ in the offgas of Nine Mile Point. 15 Their measurement yielded an off-gas composition of $95 \% \mathrm{CO}_{2}, 2.5 \% \mathrm{CO}$, and $2.5 \%$ hydrocarbons.

If $\mathrm{CO}_{2}$ is the principal species produced in the BWR coolant, the fraction of the ${ }^{15} \mathrm{CO}_{2}$ carried over in the steam can he calculated if high temperaturc partitioning and hydrolysis data for $\mathrm{CO}_{2}$, as well as data for the dissociation of water are available. A recent report by J. W. Cobble of San Diego State tabulated the high temperature free energy of formation for species of interest in the carbonate system, ${ }^{16}$ and Sweeton, et $A 1$, , has published an excellent article on the dissociation of water. 17 
From these data the following reactions were postulated for a BWR operating at a saturated steam pressure of $7.0 \mathrm{M} \mathrm{Pa} \mathrm{(1015} \mathrm{psia):}$

$$
\begin{array}{rlrl}
\mathrm{CO}_{2(\mathrm{l})} & \fallingdotseq \mathrm{CO}_{2(\mathrm{~g})} & \mathrm{K} & =7.9 \mathrm{MPa} \mathrm{kg} / \mathrm{mole} \\
\mathrm{H}_{2} \mathrm{CO}_{3(\mathrm{aq})} & =\mathrm{H}_{(\mathrm{aq})}^{+}+\mathrm{HCO}_{3}^{-}(\mathrm{aq}) & \mathrm{K}_{1}=7.5 \times 10^{-9} \mathrm{~m} \\
\mathrm{HCO}_{3}^{-}(\mathrm{aq}) & \Rightarrow \mathrm{H}_{(\mathrm{aq})}^{+}+\mathrm{CO}_{3}^{2-}(\mathrm{aq}) & \mathrm{K}_{2}=3.03 \times 10^{-12} \mathrm{~m} \\
\mathrm{H}_{2} \mathrm{O} & \Leftrightarrow \mathrm{H}_{(\mathrm{aq})}^{+}+\mathrm{OH}_{(\mathrm{aq})}^{-} & \mathrm{k}_{\mathrm{w}}=5.62 \times 10^{-12} \mathrm{~m}
\end{array}
$$

Using these equilibrium data, the chemical-species distribution in the aqueous phase was calculated to be $99.685 \% \mathrm{H}_{2} \mathrm{CO}_{3}, 0.315 \% \mathrm{HCO}_{3}{ }^{-}$, and $4.0 \times 10^{-7} \% \mathrm{CO}_{3}{ }^{2-}$. Assuming a Van der Waals gas for $\mathrm{CO}_{2}$, the distribution coefficient was estimated to be 49.5 .

Based upon the Dresden 2 flow and heat balance ${ }^{2}\left(2527 \mathrm{MW}_{\mathrm{t}}\right.$, steam fllow $4.33 \times 10^{6} \mathrm{~kg} / \mathrm{h}$, and core flow $44 \times 10^{6} \mathrm{~kg} / \mathrm{hr}$, the fraction of $\mathrm{CO}_{2}$ leaving the core that is carried by the steam is 0.845 . The remaining fraction, 0.155 , stays with the liquid as $\mathrm{H}_{2} \mathrm{CO}_{3}$ (chemically identical to $\mathrm{CO}_{2(l)}$ ), $\mathrm{HCO}_{3}{ }^{-}$, and $\mathrm{CO}_{3}{ }^{2-}$. The other potential chemical species, $\mathrm{CO}$ and $\mathrm{CH}_{4}$, are more volatile than $\mathrm{CO}_{2}$ and consequently a greater fraction of these species will be borne by the stream. Since their contribution to the total volatile radiocarbon is minor, it is justifiable to make any engineering projections and estimates based upon only one chemical species, $\mathrm{CO}_{2}$. This consideration has relevance in the calculations of the inventory of $\mathrm{C}-15$ in the turbine system components, such as the moisture separator drains.

The chemical form of radiocarbon under AWC's is not really relevant in terms of radiation levels in the steam system since the worst case condition is the carryover of the remaining $15.5 \%$ of the radiocarbon that had remained with the liquid in the non-additive condition. Therefore, the maximum fractional increase would be 1.18. This increase in radiation level is inconsequential when compared with the expected radiation field increases resulting from $\mathrm{N}-16$. 
Stenstrom's thesis sheds only limited light on what might be expected in the BWR. The following selected data represent the expected trend in the product distribution upon the addition of reducing species to the aqueous systems (Table 3-21).

The principal observation is that the addition of the reducing solute $\left(\mathrm{CH}_{4}\right)$ decreases the yield of $\mathrm{CO}_{2}$ while increasing the yield of $\mathrm{CO}$ and the aldehydes and alcohols with only minor changes in the yields of the carboxylic acids. Since the formation of aldehydes and alcohols will result in $\mathrm{C}-15$ products that are less volatile than $\mathrm{CO}_{2}$, there is a real possibility that the steam line C-15 level will be reduced under AWC's,

\subsubsection{Expected Dose Rates}

Using the normalized dose rate calculations from Subsection 3.2 .1 . and the predicted changes in $\mathrm{N}-16$ and $\mathrm{C}-15$ activities from Subsections 3.2 .2 and. 3.2 .3 , the dose rates expected for a hydrogen addition flow sheet were calculated. They are presented in Table 3-22 which shows the contributions from each major equipment piece on the turbine floor. Locations of the points considered are shown in Figure 3-5. The CIV's are major contributors and the feasibility of controlling radiation levels through the use of localized shielding at these valves is being evaluated. Also these calculaced radiation levels may be checked against actual measured dose rates 18 if the numbers are adjusted to comparable power levels. These comparisons show that the calculated values exceed the observed values by as much as a factor of two depending on exact location and modeling difficul, ty. Kecommendations for additional shielding will take these differences into consideration. If additional shielding is added, a foot-thick wall or ordinary concrete will reduce radiation levels by a factor of about six. 
Table 3-21

YIELD OF C-11 PRODUCTS IN AQUEOUS SOLUTIONS IRRADIATED

(1.0 k rad) WITH $185 \mathrm{MeV}$ PROTONS

\begin{tabular}{|c|c|c|c|c|c|c|c|c|c|c|}
\hline & Solution & $\begin{array}{c}\text { Concen }=\text { ration } \\
(\mathrm{ml})\end{array}$ & ${ }^{11} \mathrm{CO}_{2}$ & $11=0$ & $\begin{array}{c}{ }^{\perp \perp} \\
\text { Carboxylic } \\
\text { Acids } \\
\end{array}$ & $\begin{array}{c}{ }^{11} \mathrm{C} \\
\text { Aldehydes } \\
\end{array}$ & $\begin{array}{c}{ }^{11} \mathrm{C} \\
\text { AIcohols } \\
\end{array}$ & $\begin{array}{c}{ }^{11} \mathrm{C} \\
\text { Hydrocarbons }\end{array}$ & $\begin{array}{c}\text { Not } \\
\text { Identified } \\
\end{array}$ & $\begin{array}{l}\text { Dose Rate } \\
(\mathrm{rad} / \mathrm{sec}) \\
\end{array}$ \\
\hline & $\mathrm{CH}_{4}$ & 4 & 11.9 & 34.8 & 15.0 & 28.2 & 8.6 & 0.3 & 1.1 & 10 \\
\hline & None & - & 71.1 & 2.1 & 17.3 & 6.4 & 1.9 & 0.06 & 1.2 & 11 \\
\hline & $\mathrm{CH}_{4}$ & 4 & 10.8 & 34.6 & 16.2 & 29.4 & 8.1 & 0.22 & 0.8 & 13 \\
\hline & None & - & 64.4 & 2.6 & 24.4 & 5.4 & 1.8 & 0.04 & 1.4 & 14 \\
\hline & $\mathrm{CH}_{4}$ & 4 & 11.0 & 15.3 & 22.1 & 37.3 & 11.9 & 0.27 & 2.1 & 15 \\
\hline
\end{tabular}


Table 3-22

EST IMATED DRESDEN 2 TURBINE OPERATING FLOOR DOSE RATES FOR PROPOSED HYDROGEN ADDITIVE FLOW SHEET

Dose Rate at Dose Rate at Dose Rate at Dose Rate at Detector 1 Detector 2 Detector 3

Component

$(\mathrm{mR} / \mathrm{hr})$ $(\mathrm{mR} / \mathrm{hr})$

$(\mathrm{mR} / \mathrm{hr})$

Detector 4

$11.6 \mathrm{~m}$ of $20-$ in.

0.0244

17.3

0.907

11.0

steam line that enters HP turbine above floor

High pressure
turbine

0.0429

6.01

0.189

1.95

CIV-4 and piping

9.38

62.2

0.128

15.3

CIV-5 and piping

0.00772

1318.0

0.003 .33

23.9

CIV-6 and piping

$7.38 \times 10^{-6}$

55.3

$9.44 \times 10^{-5}$

15.3

Low pressure

turbine " $A$ "

Low pressure

turbine " $B$ "

0.370

5.20

0.0275

6.94

Low pressure

turbine " $\mathrm{C}$ "

0.0278

23.8

0.00370

13.3

0.00132

5.20

$4.45 \times 10^{-4}$

6.94

Total

9.85

1493.0

1.26

94.0

(154.5 for

CIV-1, 2, 3)

149.1 


\subsection{TASK B-2. ADDITIVE VOLATILITY/DECOMPOSITION - OFF-GAS SYSTEM MODIFICATION (R. J. Law)}

Objective. Each of the potential oxygen suppression additives and its volatile decomposition products will be continuously stripped into the steam phase in the reactor vessel. These volatile components are subsequently extracted from the condenser by the steam jet air ejector (SJAE) and, with any fission product gases present, constitute the inlet flow of the off-gas treatment system. The exact magnitude of the inlet gas flow to the offgas for each additive must be determined. It is possible that the gas flow will be several times larger than that in the current, no-additive situation and will dictate an increase in the size of the system components and piping. In addition, the altered composition (including trace impurities) of the offgas may alter the recombiner performance, affect the hydrogen explosion hazard, and will be of special significance if hydrogen is to be recycled as the feedwater additive.

\subsubsection{Off-Gas Base Line Impurtty Measurements}

The objectives of the base line impurity analysis program were to determine the concentrations of trace gas components $\left(\mathrm{Kr}, \mathrm{Xe}, \mathrm{CO}, \mathrm{CO}_{2}, \mathrm{NO}, \mathrm{NO}_{2}, \mathrm{O}_{3}, \mathrm{CH}_{4}\right.$, and higher hydrocarbons) in the offgas of a typical BWR. These tests were conducted at Nine Mile Point 1 during July and August of 1978 as a supplementary task to the Alternate Water Chemistry Additive Program. The results will be used to evaluate (a) the potential interaction of the impurities with an additive, and (b) the overall effects of these impurities in the various modifications being postulated for the off-gas system.

Nine-Mile Point 1 was selected as the test site since it has a recombiner typical of present BWR off-gas systems and there existed an approved sampling device in the Improved Noble Gas Retention System (INGR) that was tied into the off-gas system at the proper location. This eliminated the cost and time of installing sample taps, sampling hardware and obtaining subsequent site agreements, approvals, and procedures. 


\subsubsection{Test Location}

The test equipment was located on the 250-ft level, southwest corner of the Nine Mile Point 1 turbine building, adjacent to the 30-min holdup pipe. The INGR sampling system was used to supply an off-gas sample for analysis then return it to the main condenser for subsequent of $f$-gas treatment. Figure 3-9 indicates that portion of the system used for these tests.

\subsubsection{Site Conditions}

The Nine Mile Point 1 off-gas flow rate was checked daily during the testing period. One week prior to the initiation of the testing, the off-gas flow rate increased from $5.7 \mathrm{~L} / \mathrm{S}$ to $8.5 \mathrm{~L} / \mathrm{S}$. This higher rate persisted throughout the duration of the analysis program.

The electric output during the test period was approximately $520 \mathrm{MW}$. The derated output was caused by the loss of one recirculation pump and the end-of-cycle (EOC) coast-down.

\subsubsection{Test Equipmenl}

The analysis equipment used for these tests is identified in Table 3-23 for each component.

The inlet and outlet tie-ins of the analysis equipment to the INGR sampling system are diagrammed in Figures 3-10 through 3-13 for each of the techniques used. 


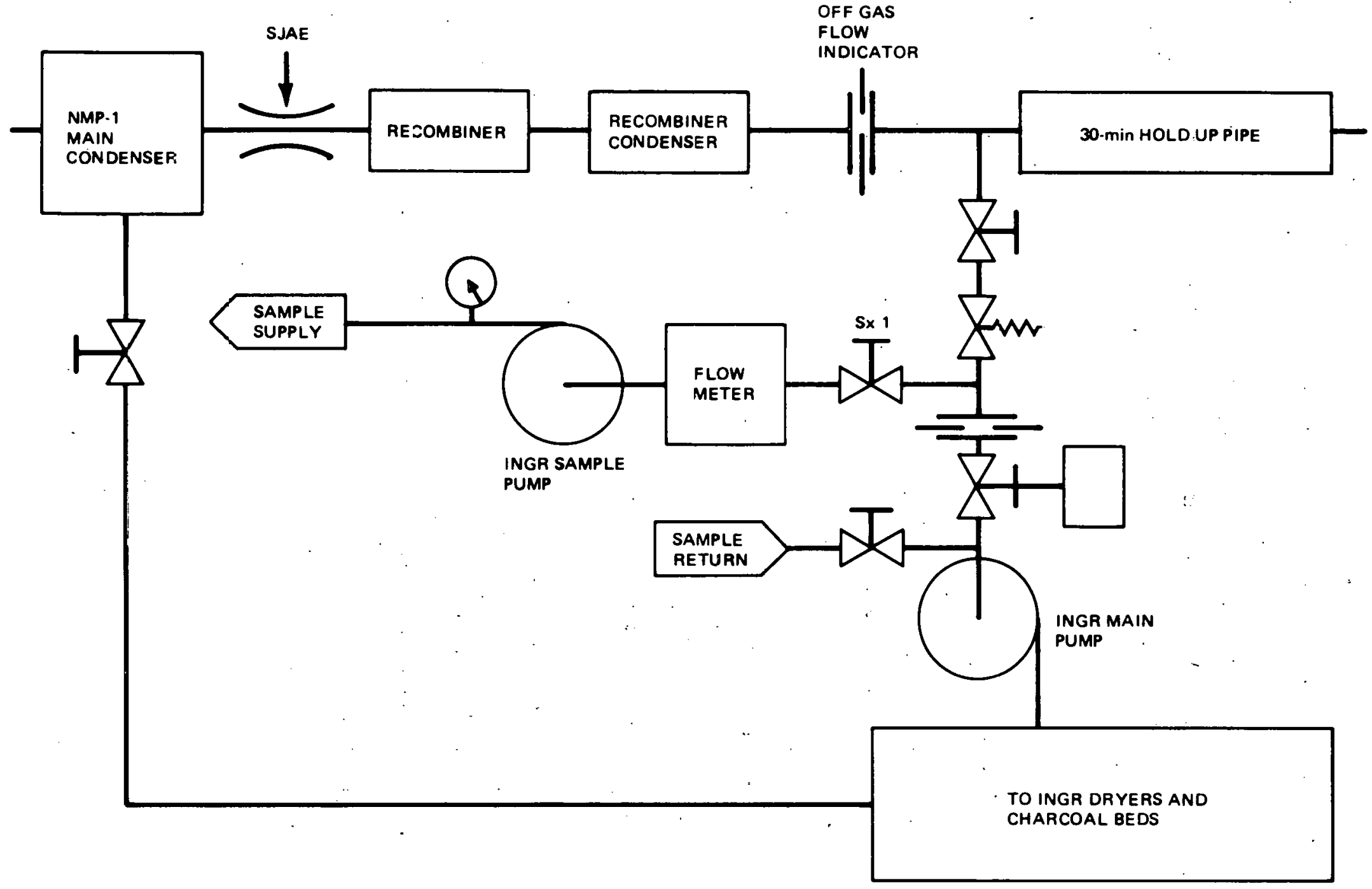


Figure 3-10 shows the gas chromatograph (GC) sampling controls and flow paths for the calibration and sample gases. The GC sample loop pressure was maintained by the backpressure regulator,'BPR-1, located in the return 1ine. The rotameter, $\mathrm{RM}-1$, was used to verify that the required volume of sample gas (purge) passed through the loop before the next analysis (>5 times the GC loop volume). A schematic diagram of the internal GC flow paths and controls is shown in Figure 3-14.

The mass spectrometer (MS) sample flow path used to measure $\mathrm{Kr}$ is shown in Flgure 3=11. The lis sample pump (VP=1) was used ie draw the sanple lu the mass spectrometer and reduce the pressure upstream of the first orifice (FO-1). The oil-vacuum pump (VP-2) was used to reduce the pressure upstream of the second orifice (FO-2) and to maintain a low pressure, (<100 mtorr) downstream of the turbo-molecular pump (VP-3). The analysis control point for the mass spectrometer was the internal total-pressure of the analyzer chamber (1.0x $10^{-6}$ torr) measured with an ion gauge (IG). This pressure was maintained for

Table 3-23

INSTRUMENTATION

1. Tracor Gas Chromatograph, MT-150

2. Dasibi Ozone Monitor, Model 8000

3. Drager Adsorption Tubes ( $\mathrm{NO}$ and $\mathrm{NO}_{2}$ )

4. UTI Mass Spectrometer

5. EGG 880 Dew Point Hygrometer
$\mathrm{Xe}, \mathrm{CO}, \mathrm{CO}_{2}, \mathrm{CH}_{4}$ and higher hydrocarbons

$\mathrm{O}_{3}$

NO, $\mathrm{NO}_{2}, \mathrm{O}_{3}, \mathrm{Cl}_{2}$

$\mathrm{Kr}$

Humidity 


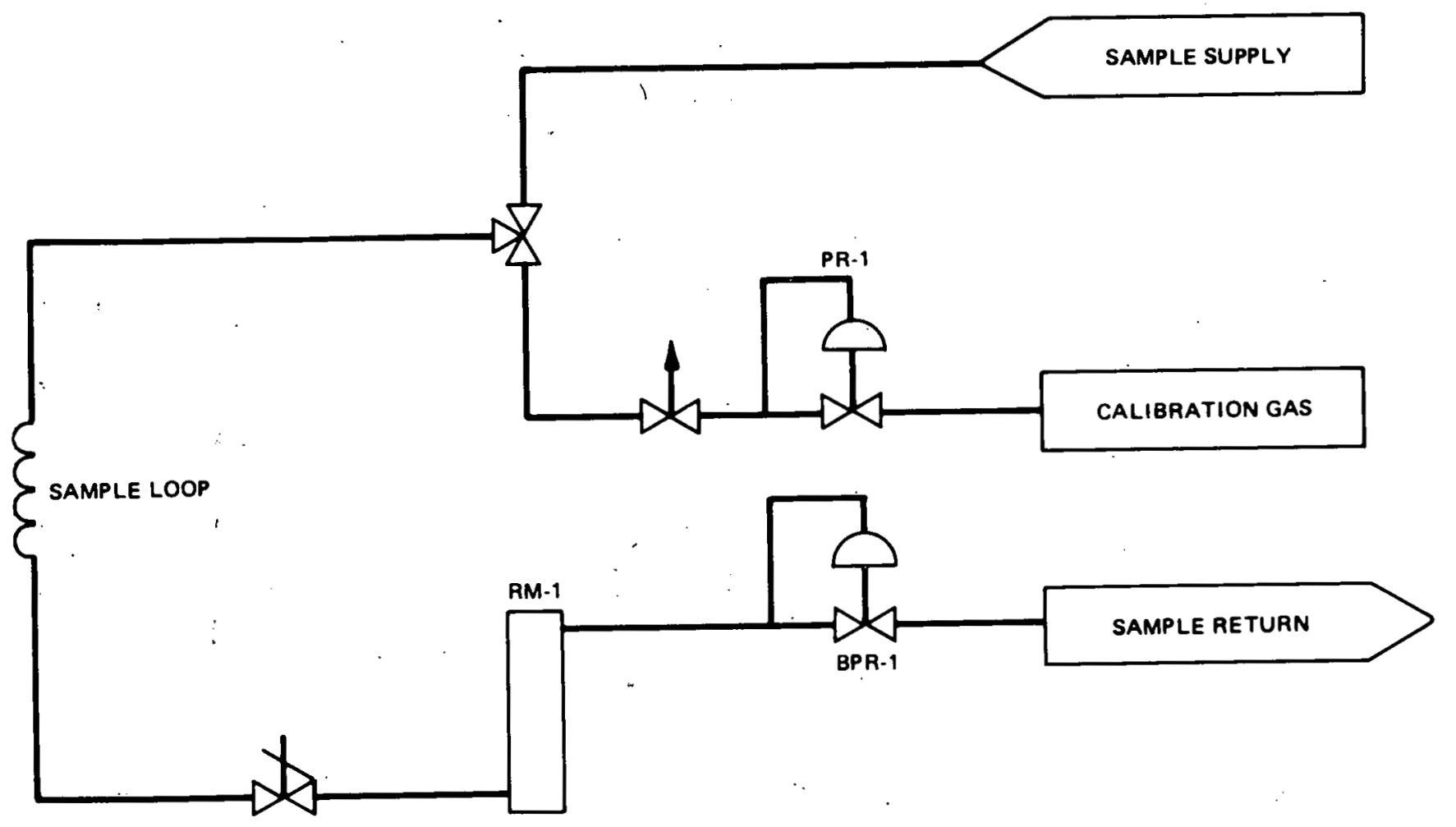

Figure 3-10. Gas Chromatograph Sampling System 


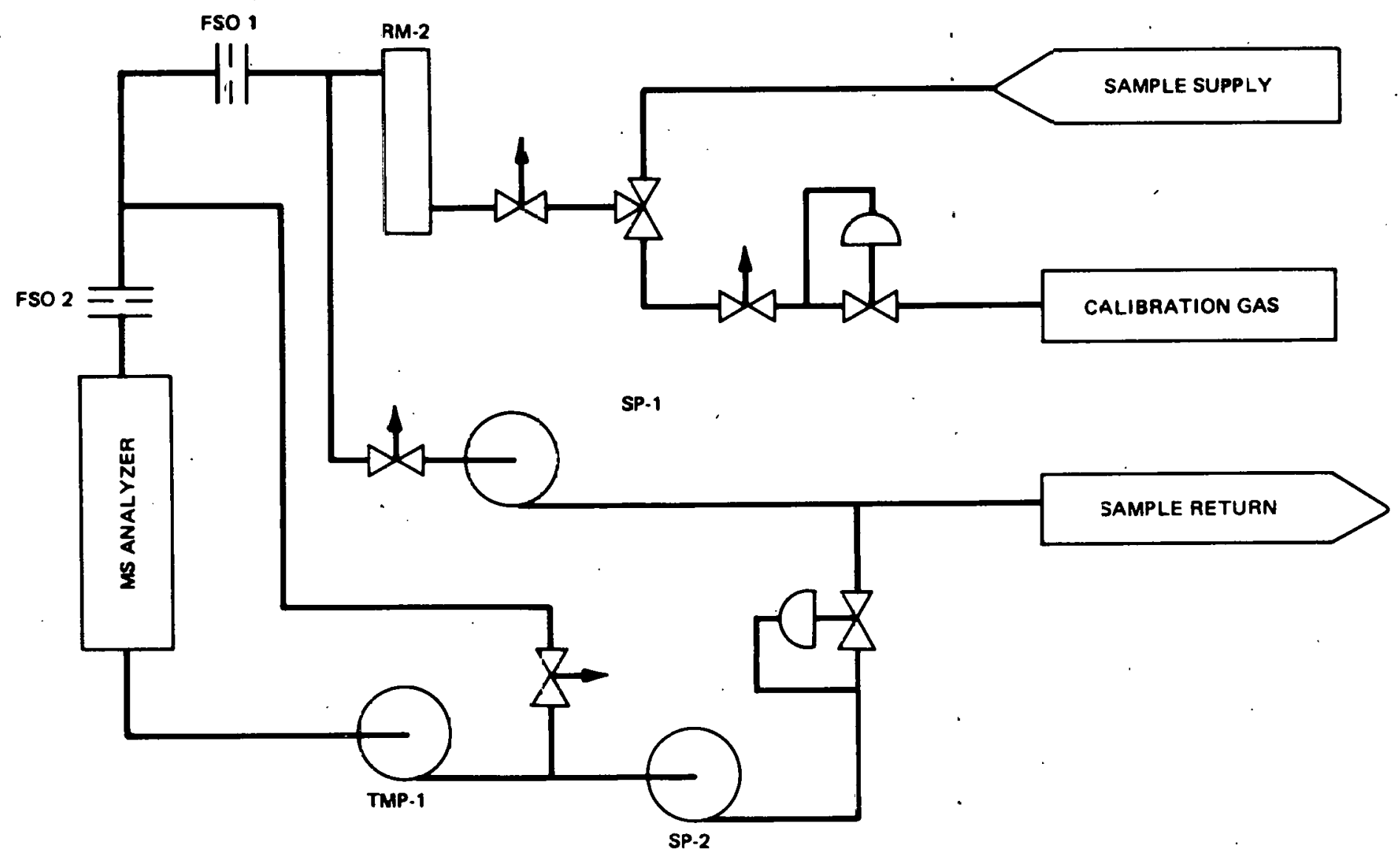

Figure 3-11. Mass Spectrometer Samplizg System 


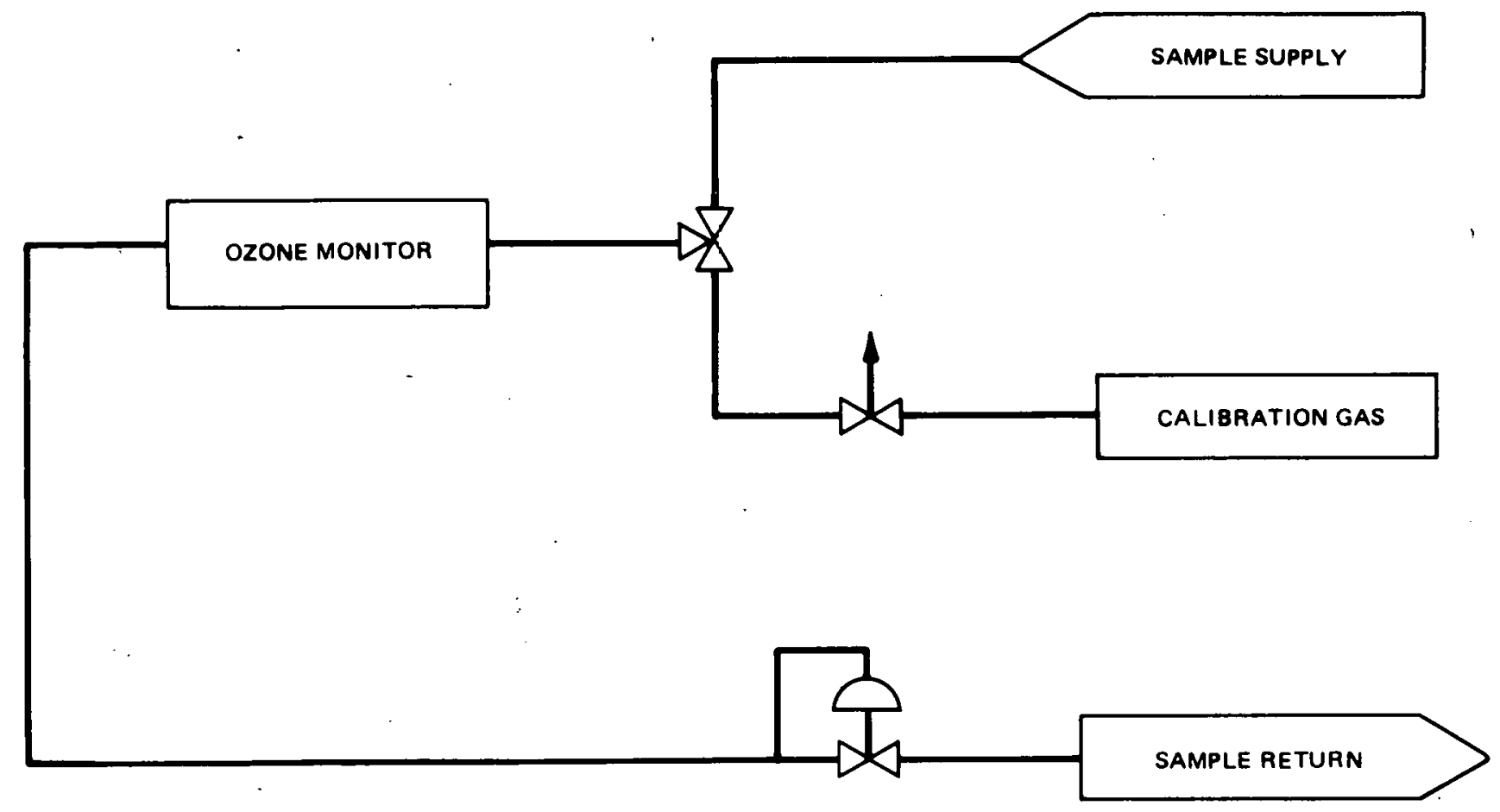

Figure 3-12. Ozone Monitoring Sampling System 


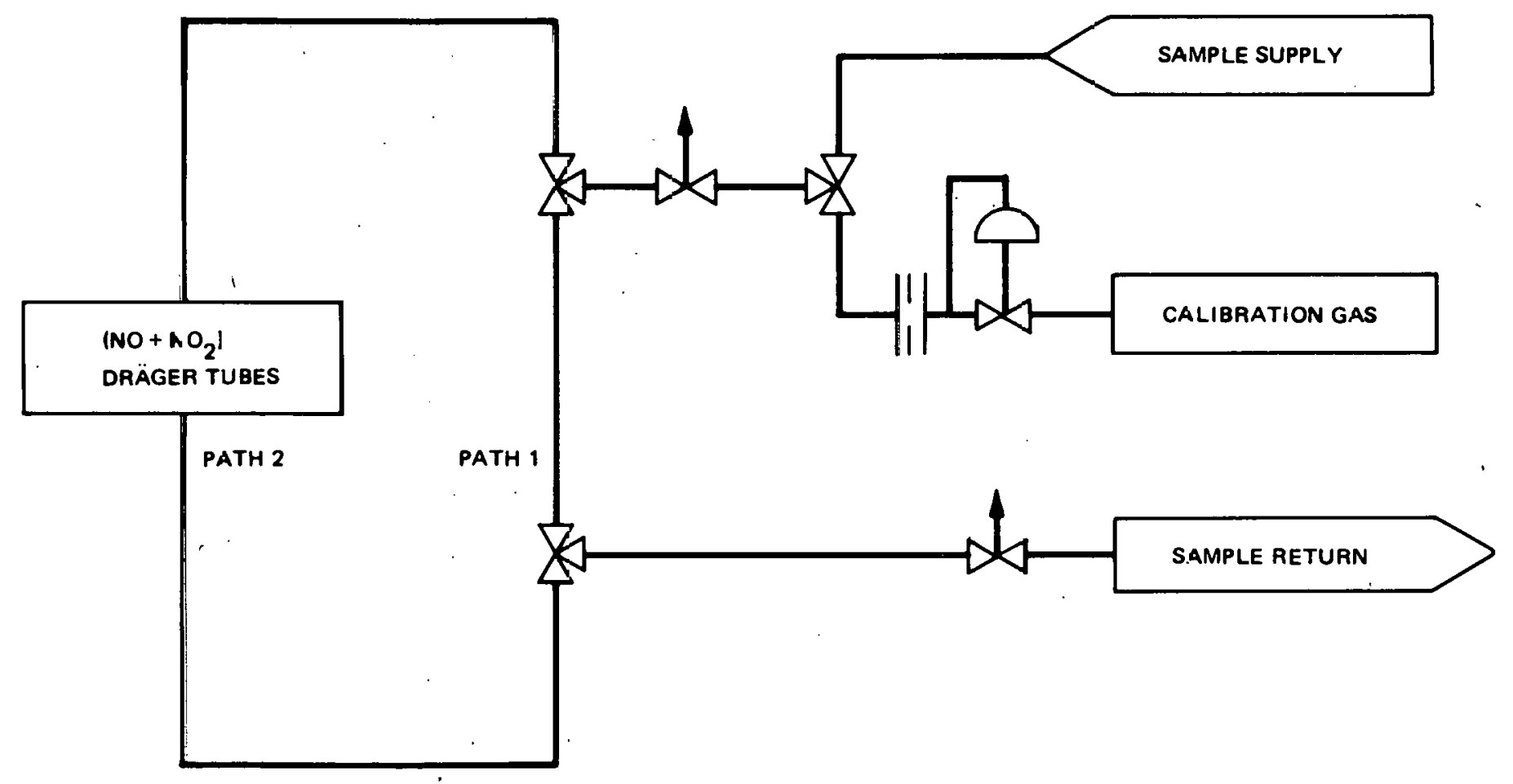

Fizure 3-13. $\left(\mathrm{NO}^{\mathrm{NO}} \mathrm{N}_{2}\right)$ Drag̈er Adsorption Tube Sam?ling System 


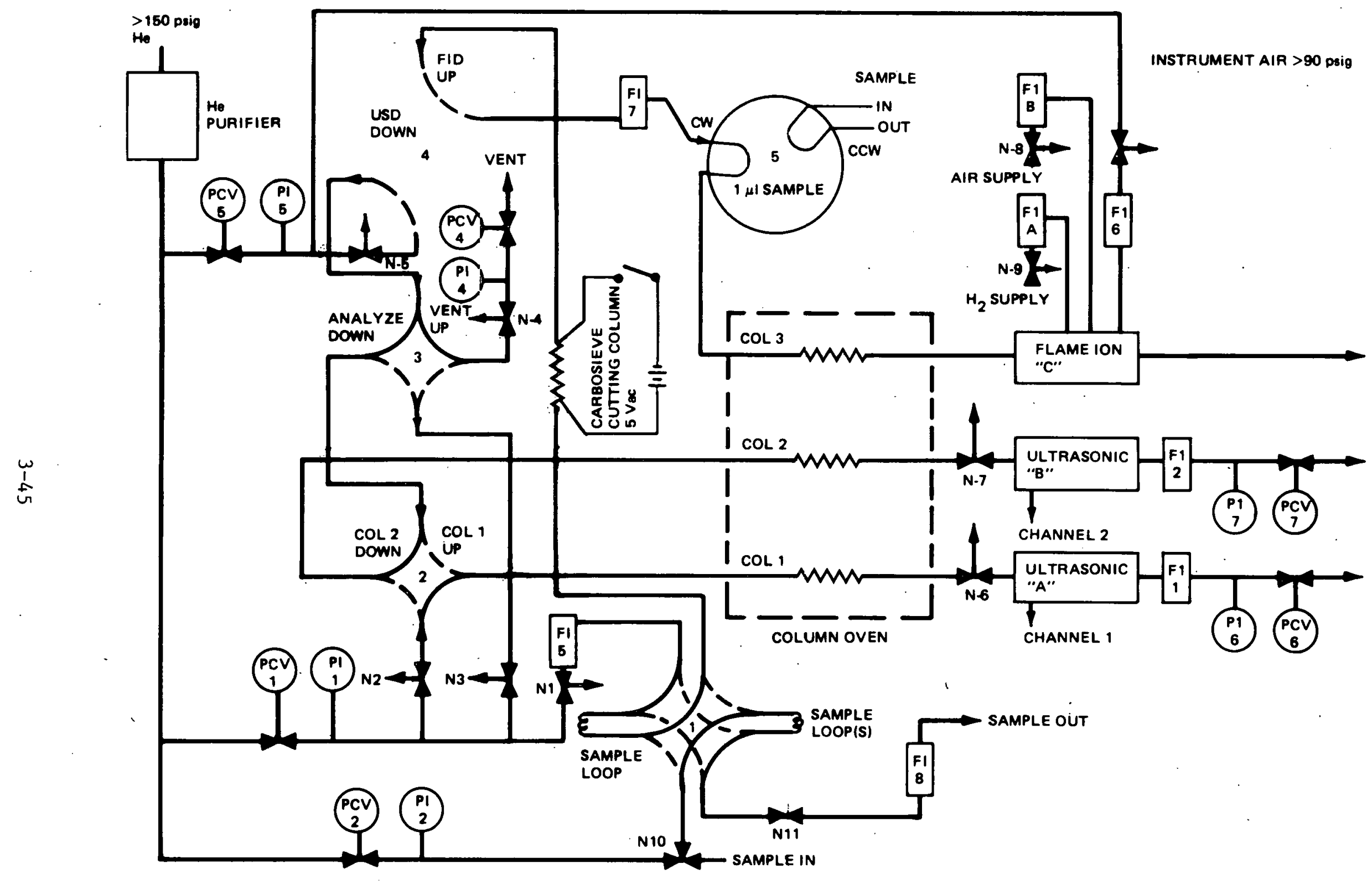

Figure 3-14. Gas Chromatograph Internal Flow Paths 
the analysis of both the sample and calibration gases. The MS output signal was, therefore, a direct measurement of the $\mathrm{Kr}$ partial pressure.

Figure 3-12 shows the sampler controls required for the specific ozone monitor. Operational details for the above techniques are in the test plan and procedure for this task.

The $\mathrm{NO}$ and $\mathrm{NO}_{2}$ analysis was performed with the backup adsorption tubes due to a malfunction of the primary monitoring system. For low $\mathrm{NO}_{\mathrm{x}}$ concentrations, the monitor detection cell contains a very thin membrane which apparently was damaged during shipment. Atter considerable testing, a second cell was shipped to the site in a neutral pressure container. All precautions were taken to prevent membrane damage. After extensive tests were performed with the new detector, as per discussions with the manufacturer, the exact problem could still not be diagnosed or solved without return of the entire system to the factory.

Both the monitor and adsorption tube measuring techniques were selected for their performance with radioactive gas samples. Other $\mathrm{NO}$ and $\mathrm{NO}_{2}$ analysis techniques have been tested or examined by Gas Technology, e.g., GC, MS, chemiluminescence and wet chemistry. Since the nitrogen oxides are very reactive and are usually present at low concentration in the offgas, GC techniques do not provide the required accuracy and precision. The mass spectrometer was not usable since interference due to high concentrations of mass neighbors $\mathrm{N}_{2}$ and $\mathrm{O}_{2}$ for NO and $\mathrm{CO}_{2}$ for $\mathrm{NO}_{2} \cdot$ Chemiluminescent detectors were tested for the $\bar{K} \bar{B}$ study. This type of detector was too sensitive to radiation emitted from the gas sample. Wet chemistry techniques were not considered for NMP-1 because of the gas release hazards and the expense of special wet chemistry facilities required at the sampling location.

Figure 3-13 shows the sampling schematic used with the adsorption tubes. The exact procedures, tests, and supplementary calibrations required for the adsorption tube method are contained in the test procedures. 


\subsubsection{Analysis and Results}

The operational details for each component analysis, except for $\mathrm{NO}$ and $\mathrm{NO}_{2}$, are located in the test procedure and the associated standard.operating or calibration procedures. The final concentration results of the measured impurities, with the lower measurable limits are listed in Table 3-24.

In general, the detection limit was based on a signal-to-noise ratio of $2: 1$.

The analysis of $\mathrm{NO}^{\mathrm{NO}} \mathrm{N}_{2}$ was complicated by the closed-loop approach required to analyze the radioactive gas, versus the normal use of the tubes utilizing the open-exhausted hand-pump. The tube markings are calibrated for a particular number of pump strokes. Although the pump volume (100 cc) was accurate, the flow varies from $>1000 \mathrm{cc} / \mathrm{min}$ to zero in a nonlinear manner during each stroke. This type of flow characteristic could not be duplicated with the closed-loop sampling system. The response of the detection tube to variations in constant flow rates were measured and are reported in the test file, Section 4.2.2.11. The responses of the tubes tested with off-gas' samples are listed in Table 3-25.

Table 3-24

OFFGAS IMPURITY CONCENTRATIONS AT NINE MILE POINT 1, SUMMER OF 1978

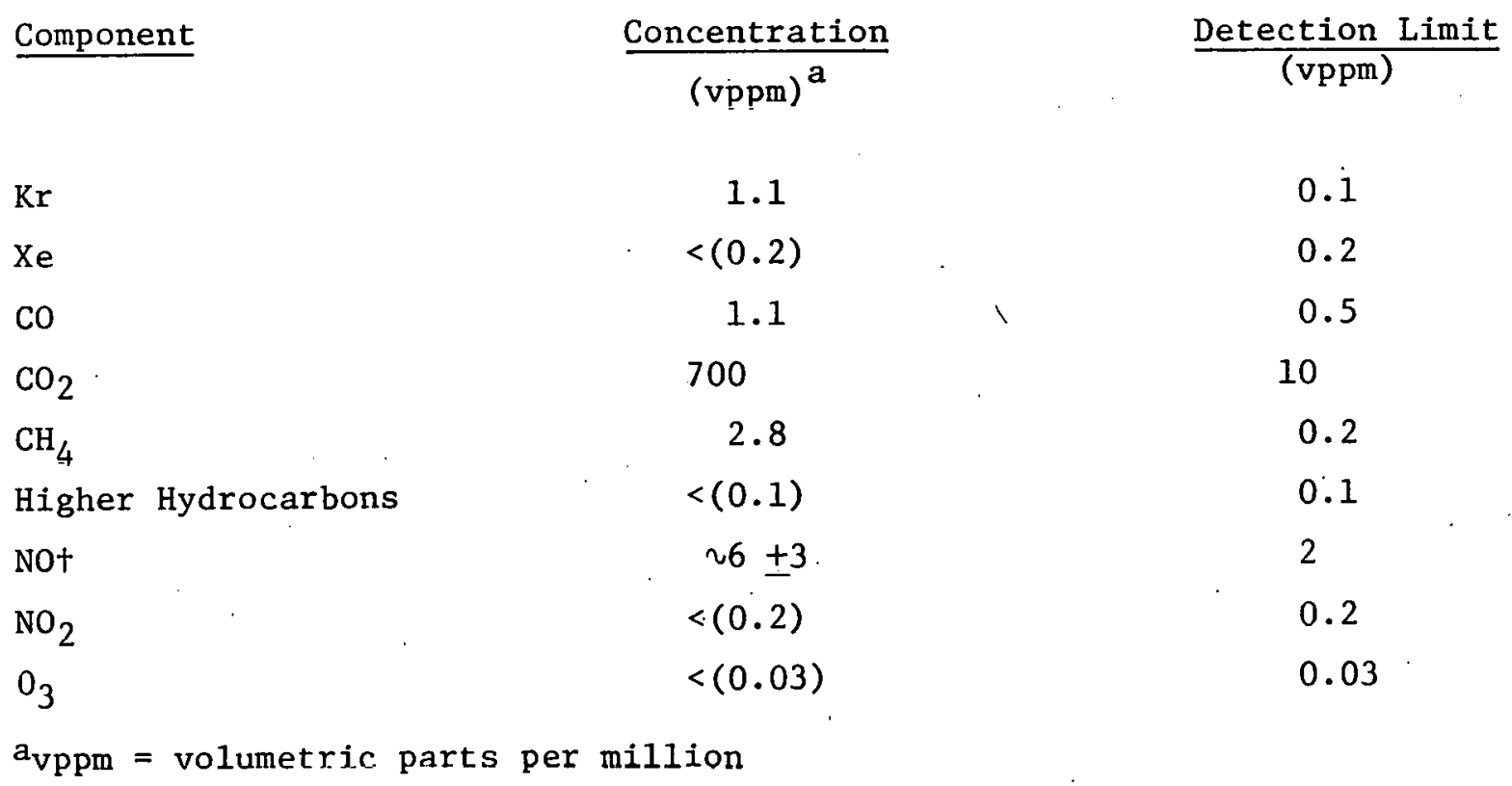


Table 3-25

\section{QUALITATIVE RESULTS OF VARIOUS ADSORPTION TUBES TO OFF-GAS SAMPLES \\ (at $100 \mathrm{sccm}$ for $5 \mathrm{~min}$ )}

\begin{tabular}{|c|c|}
\hline Tube Type & Response \\
\hline $\mathrm{NO}+\mathrm{NO}_{2}$ (NO catalyzed to $\mathrm{NO}_{2}$ ) & Blue color change \\
\hline Ozone & No change \\
\hline $\mathrm{NO}_{2}$ & No change \\
\hline
\end{tabular}

According to the manufacturer, only chlorine $\left(\mathrm{Cl}_{2}\right)$ and Ozone $\left(\mathrm{O}_{3}\right)$ interfere with the selectivity of the $\mathrm{NO}_{2}$ detecting agent. The total nitrogen oxides measured with the $\mathrm{NO}^{-} \mathrm{NO}_{2}$ type tube are obtained by oxidizing the NO to $\mathrm{NO}_{2}$ in the sample gas with a $\mathrm{Cr}$ (VI) catalyst located in the tube inlet. The $\mathrm{NO}_{2}$ type tube does not contain $\mathrm{CR}$ (VI) and is not sensitive to NO.. No response was observed using the $\mathrm{NO}_{2}$ or the $\mathrm{O}_{3}$ type tubes; therefore, only NO and not $\mathrm{NO}_{2}, \mathrm{O}_{3}$ or $\mathrm{Cl}_{2}$ was responsible for the color change in the $\mathrm{NO}^{2} \mathrm{NO}_{2}$ tubes. The lack of response with the $\mathrm{O}_{3}$ detection tubes confirms the result obtained previously with the ozone monitor.

\subsubsection{Discussion}

The Nine Mile Point I results were similar to those obtained from previous studies performed at $K R B$ and are also in agreement with values expected from turbine-building air inleakage. Turbine building air analyses were performed for $\mathrm{Kr}, \mathrm{CO}, \mathrm{CO}_{2}$ and $\mathrm{NO}^{\mathrm{NO}} \mathrm{N}_{2}$. These tests showed a slullar duuuul of $\mathrm{Kr}$, less than half as much $\mathrm{CO}$ and very little $\mathrm{NO}^{\mathrm{NO}} \mathrm{N}_{2}(<0.1 \mathrm{ppm})$. It appears that $\mathrm{CO}$ and NO are generated in the reactor system or recombiner.

Two accidental releases of $\mathrm{CO}_{2}$ into the 250-ft level from the fire extinguishment system. occurred 1 and 2 weeks prior to the $\mathrm{CO}_{2}$ off-gas analysis. There was no sure way of determining if these releases had any effect on the later $\mathrm{CO}_{2}$ analysis but measurements of the local turbine building air for $\mathrm{CO}_{2}$ (300 vppm) agreed with the reported normal air concentration. The 700 vppm 
$\mathrm{CO}_{2}$ value measured in the offgas is similar to the high concentrations obtained at KRB in 1971 ( 800 to $1000 \mathrm{vppm}$ ). and in 1974 (1500 vppm).

The potential interactions of these impurities with the proposed additives and the effects on the off-gas treatment system are being evaluated.

\subsubsection{Off-Gas System Mass Balances}

The mass balance flow sheets for the single-pass hydrogen addition cases to maintain $10 \mathrm{ppb}$ and $50 \mathrm{ppb} \mathrm{O}_{2}$ in the core exit water are shown in Figures 3-15 and 3-16, respectively.

\subsubsection{Potential Problems}

For these two cases, the hydrogen in the steam is partially recombined with the condenser inleakage oxygen in the off-gas catalytic recombiner. The excess hydrogen then passes through the off-gas treatment system with the condenser inleakage nitrogen. This single-pass approach is simple but certain questions must be answered before this approach can be utilized. The major concerns are:

a. Operational. The total flow rate through the off-gas treatment system could be 2 to 3 times the design flow rate, depending on the level of hydrogen addition. At the higher flow rates, the operation of the desiccant dryer, used to condition the offgas to an appropriate dew point, would be marginal. The decontamination factor provided by the activated carbon column would be reduced and the pressure drop across the off-gas system would be increased at the higher flow rates.

b. Safety. The off-gas hydrogen concentration downstream of the recombiner would be approximately 80 percent. Any air inleakage into the off-gas system would constitute an explosion hazard. The General Electric supplied off-gas treatment systems operate at a 
$H_{2}$ ADDITION

$61.9 \mathrm{scfm}$

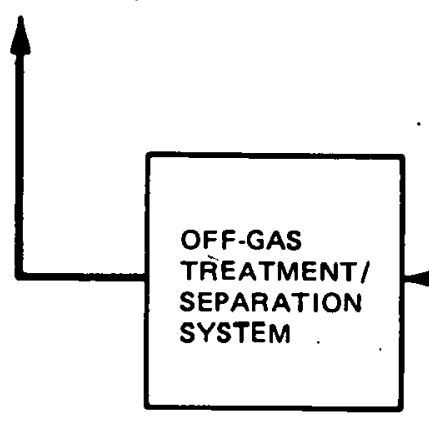

$$
\begin{aligned}
& H_{2}=53.3 \mathrm{scfm} \\
& N_{2}=15.8 \mathrm{scfm}
\end{aligned}
$$
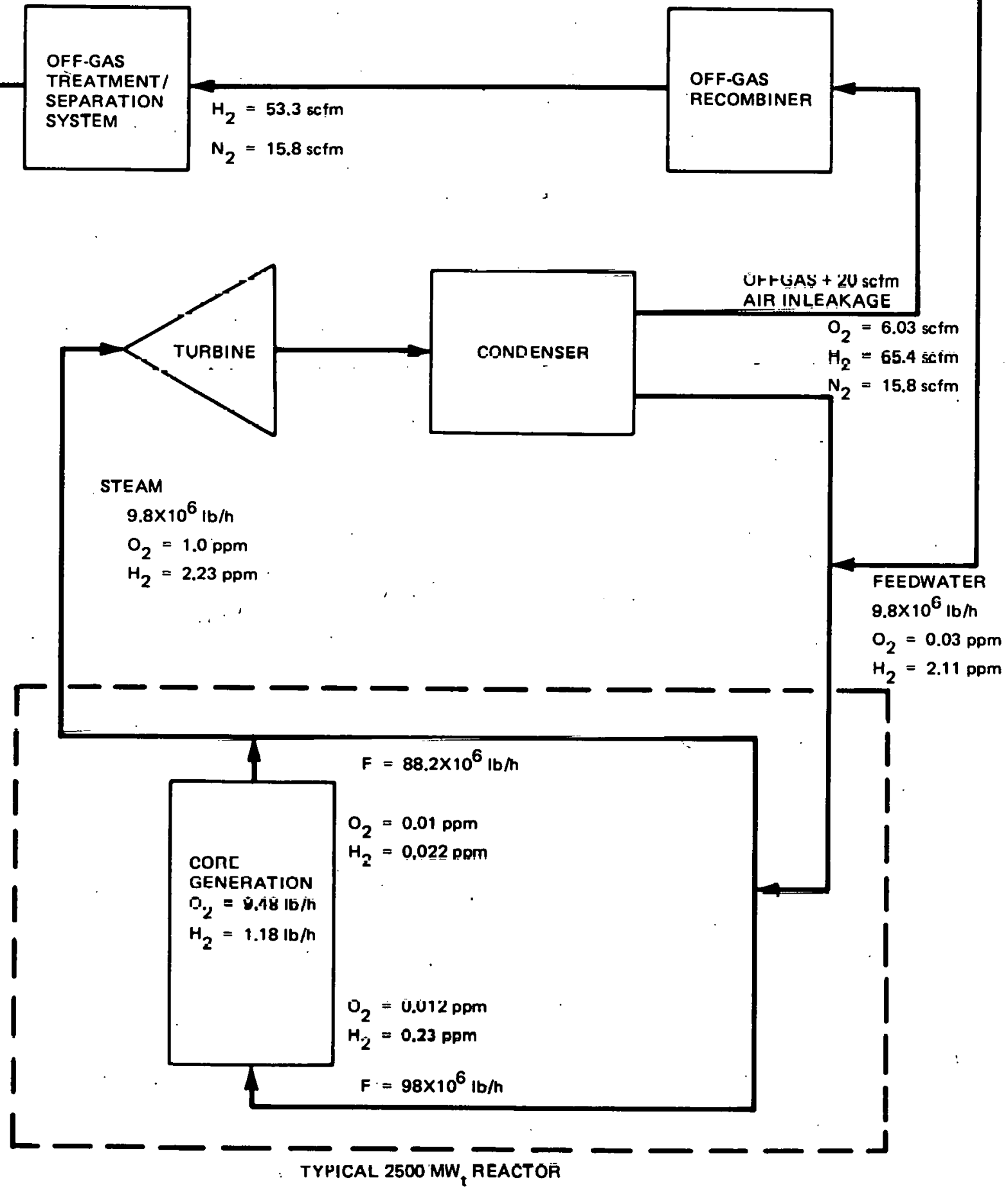

Figure 3-15. Hydrogen Addition-10 ppb Oxygen in Core Exit Water (One Pass for Hydrogen) 


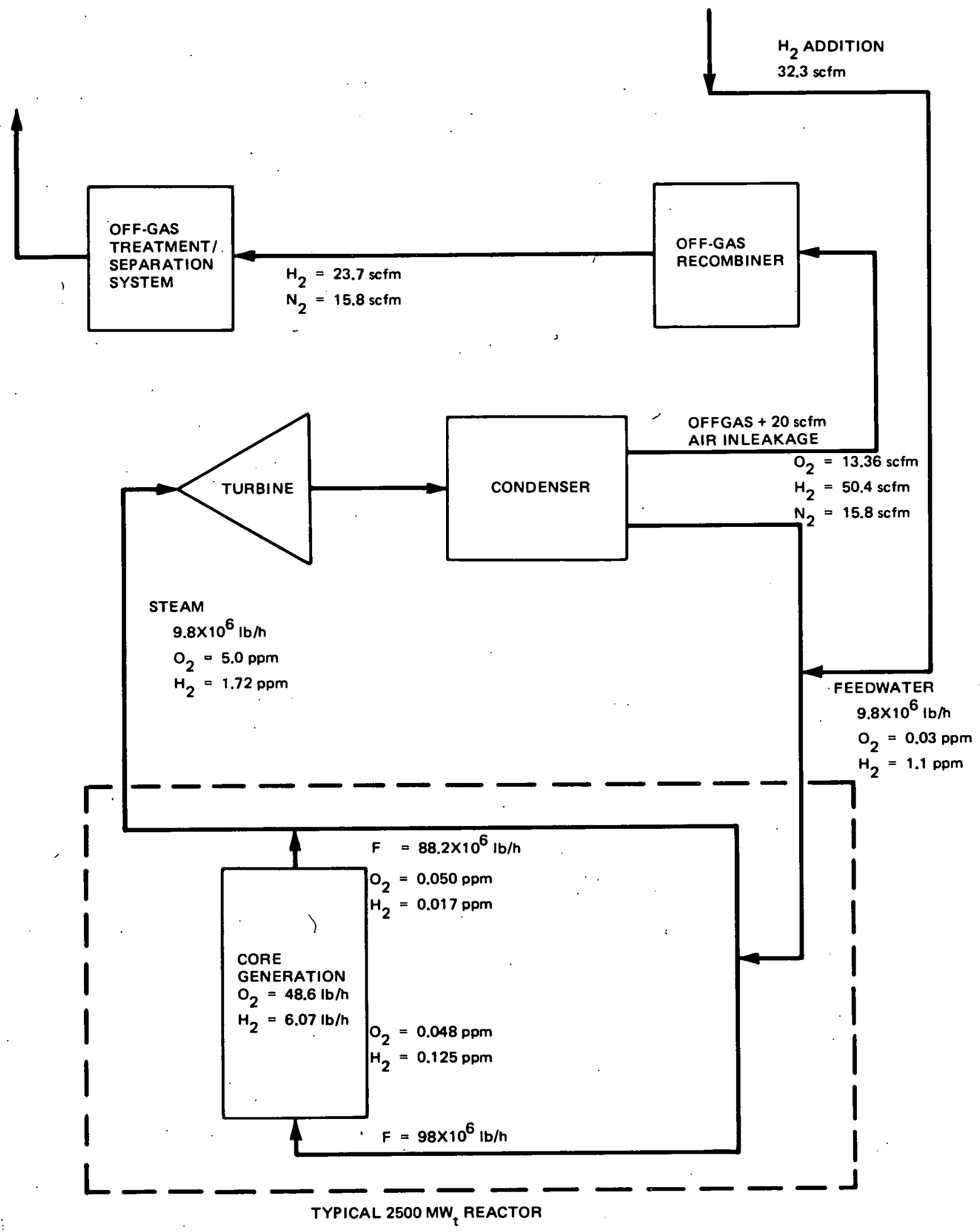

Figure 3-16. Hydrogen Addition-50 ppb Oxygen in Core Exit Water (Une Pass for Hydrogen) 
slight positive pressure such that air inleakage should not be a problem. However, some off-gas systems supplied by other vendors operate at. a negative pressure. Air inleakage into these systems could be a potential problem.

The single-pass hydrogen addition is a simple approach requiring no changes to the present off-gas system if the identified problem areas can be properly addressed.

\subsubsection{Improved System}

One method for resolving these problem areas is to add oxygen immediately upstream of the off-gas recombiner. With oxygen addition, the gas flow rate downstream of the recombiner is reduced and the explosion hazard is eliminated because the hydrogen is totally recombined. Figures 3-17 and 3-18 show the mass balance flow sheets for hydrogen addition to maintain $10 \mathrm{ppb}$ and $50 \mathrm{ppb} \mathrm{O}_{2}$ in the core exit water and with oxygen addition at the inlet of the off-gas recombiner to oxidize essentially all the hydrogen in the offgas.

With this oxygen addition approach the off-gas flow rate is below the design value of the off-gas treatment system. The composition of the offgas downstream of the recombiner would be essentially only nitrogen; thus eliminating the safety problems.

A preliminary design of an oxygen addition system is shown. in Figure 3-19. The equipment and installation costs for the oxygen addition system have been estimated and are shown in Table 3-26. The operating costs for the oxygen would be approximately $\$ 6500 / \mathrm{mo}$ for the $10 \mathrm{ppb}$ case and $\$ 3000 / \mathrm{mo}$ for the $50 \mathrm{ppb}$ reactor water oxygen concentration case.

\subsubsection{Current Activities}

Effort on this task is being directed toward developing the mass balance flow sheets for the other two additives and for the hydrogen addition with hydrogen 


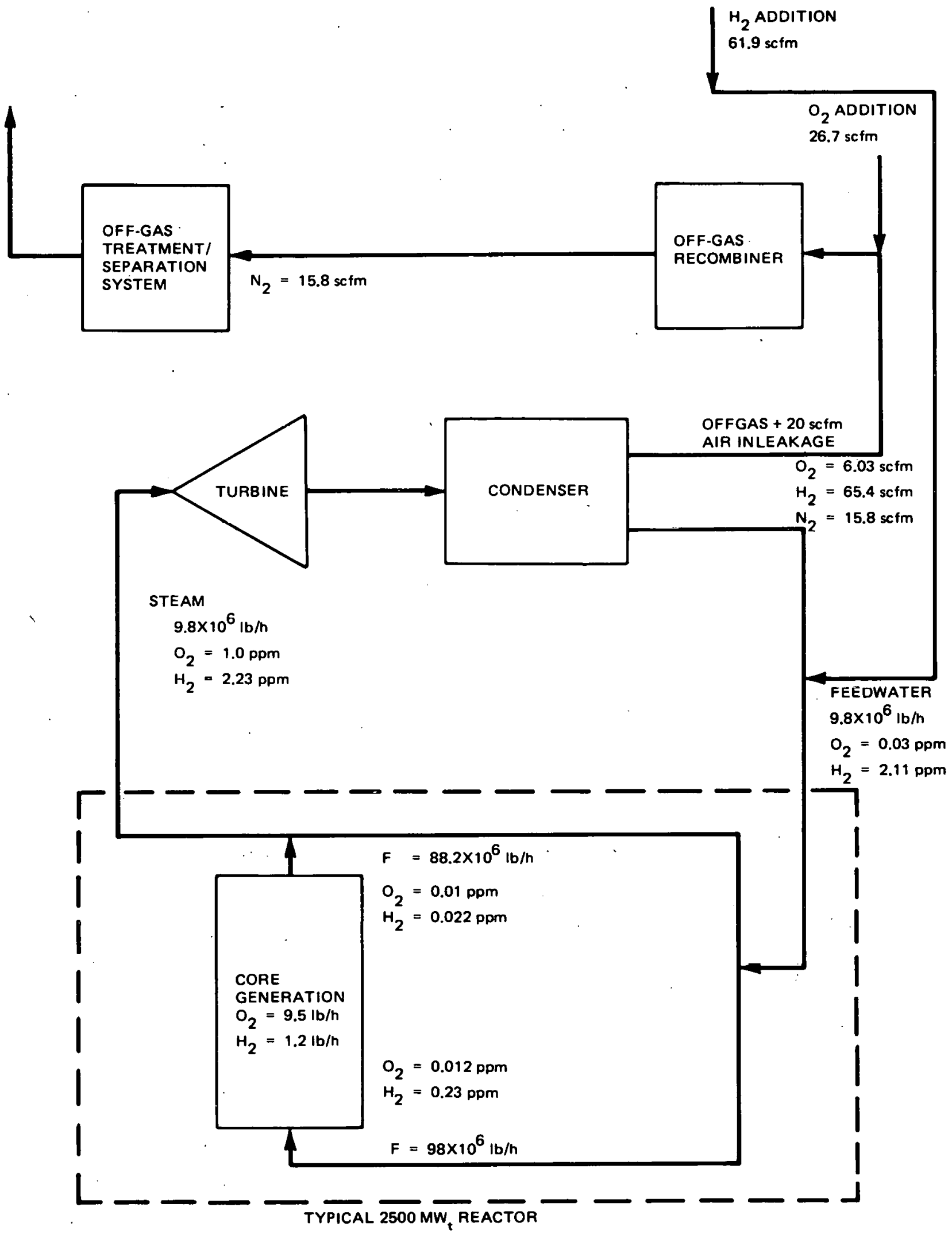

F1gure 3-17. Hydrogen Addition-10 ppb Oxygen in Core Exit Water (One Pass for Hydrogen and Oxygen Addition to Recomblne Hydrogen) 
$H_{2}$ ADDITION

$32.3 \mathrm{scfm}$

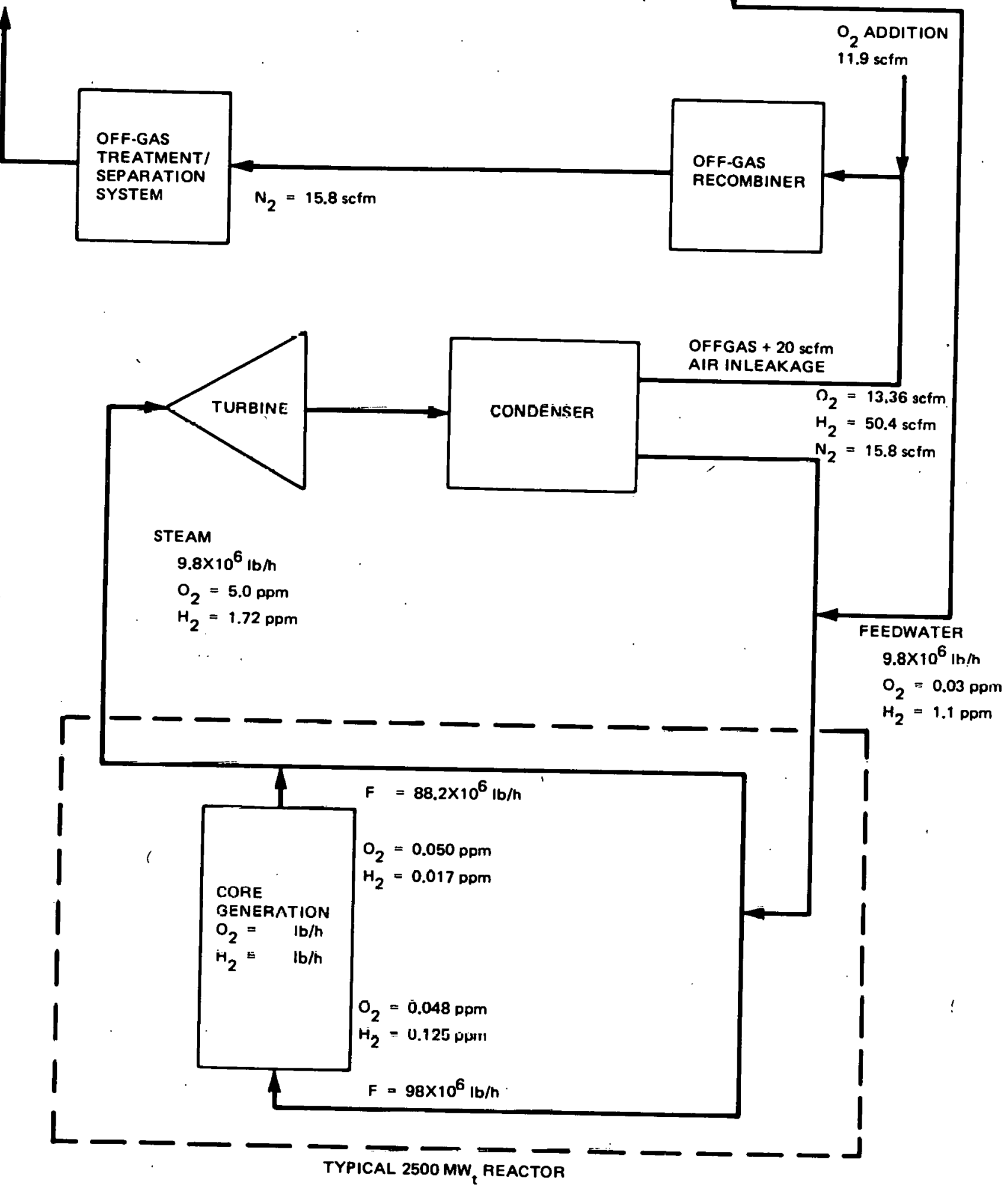

Figure 3-18. Hydrogen Addition-50 ppb Oxygen in Core Exit Water (One Pass for Hydrogen and Oxygen Addition to Recombine Hydrogen) 


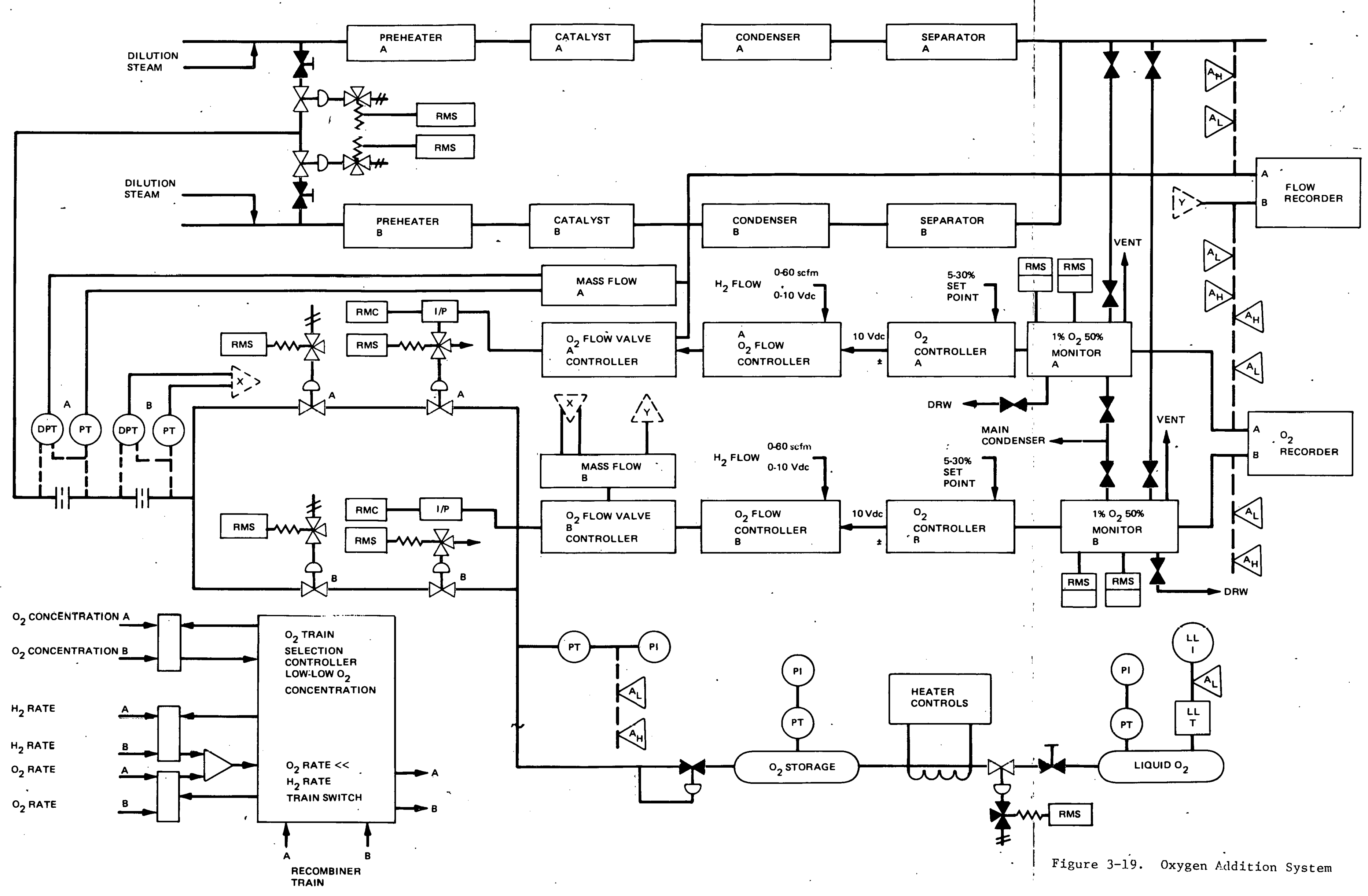


separation downstream of the off-gas recombiner. This task will be completed during the forthcoming quarter.

Table 3-26

$0_{2}$ ADDITION SYSTEM EQUIPMENT AND INSTALLATION COST

I. Liquid oxygen supply system consisting of a 6000-gal vessel and vaporizer and installation

II. Oxygen addition control system

A. Equ1pment consisting of $\mathrm{O}_{2}$ analyzers, flow element, controllers, va1,ves and piping

B. Engineering, installation and testing 170K

Total 
NEDC-23856-3

\subsection{TASK B-3. COOLANT LEAKAGE MONITORING (L.L. Sundberg)}

Objective. Uncorrected condenser leakage can quickly exhaust the BWR full flow, condensate demineralizers and inject undesirable impurities, including chloride, into the reactor water. With ionic additives such as $\mathrm{NH}_{3}$ or $\mathrm{N}_{2} \mathrm{H}_{4}$, the condensate conductivity becomes about $35 \mu \mathrm{s} / \mathrm{cm}$ and simple conductivity is no longer a sensitive leakage monitoring technique. An alternative leakage detection system must be selected and evaluated.

\subsubsection{Chloride Monitor}

An in-line specific-ion electrode chloride monitor has been received from its vendor, Orion Research Corporation. The unit is very similar to the sodium monitor in many respects. The total size of the package, plumbing, polishing colúm, and dynamic calibrator are identical. There are, however, two subtle differences. In the chloride analyzer, the process stream passes through 2 feet of diffusion tubing which is immersed in $88 \%$ formic acid. Gas phase diffusion of formic acid lowers the $\mathrm{pH}$ of the sample stream, thereby decreasing the concentration of $\mathrm{OH}^{-}$and improving the selectivity of the electrode. The $\mathrm{pH}$ of the effluent is roughly 3.0. There is no temperature compensation circuitry in the chloride monitor. The temperature is held constant by a circulating water bath which operates at $4^{\circ} \mathrm{C}\left(39^{\circ} \mathrm{F}\right)$.

\subsubsection{Instrument Calibration}

The sodium and chloride monitors were installed in the laboratury and calibrated using mechanically driven calibration syiringes and standard calibration solutions of $\mathrm{NaCl}$. In spite of the overall simplicity of the syringe calibrators, they were checked and are very accurate. A known standard was injected at various flow rates into the process $\mathrm{stream}(40 \mathrm{~m} / / \mathrm{min})$. The calculated standard values and the meter readings are in excellent agreement within the limitations of reading the meter. 


\begin{tabular}{c} 
Calculated $\mathrm{Cl}^{-}$ \\
$50 \mathrm{ppb}$ \\
40 \\
30 \\
20 \\
10 \\
5 \\
2.5 \\
25 \\
28 \\
Calculated $\mathrm{Na}^{+}$ \\
$100 \mathrm{ppb}$ \\
50 \\
10 \\
5 \\
1 \\
0 \\
\hline
\end{tabular}

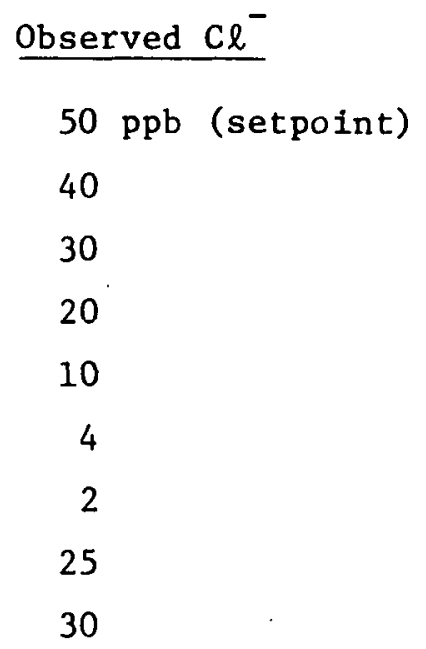

Observed $\mathrm{Na}^{+}$

$100 \mathrm{ppb}$ (setpoint)

50

10

5

1

0.15

The calibration of these analyzers requires extremely accurate delivery on the calibrator and rotameters. These devices are calibrated by classical stupwalch/gravimetric techniques. If and when these units go to a site, formal calibration procedures will be generated.

The ability to observe sodium and chloride "free" water appears quite good. After calibration, the building demineralized water was passed through the ion-exchange columns built into the systems. The chloride monitor indeed read $0 \mathrm{ppb}$, in the absence of flow,perturbations. The base line sodium value was $0.1 .5 \mathrm{ppb}$ (lowest scale reading $0.1 \mathrm{ppb}$, zero undelined on logarithmic scale). The mixed bed resin column is manufactured by Barnsted. The particular resins are HCR (cation) and SBR-P (anion). These acronyms are from Nalco Chemical Co. (Nalcite), the material distributor. Thus, the cation resin could be Duolite C-20 (Diamond Alkali), Dowex 50 (Dow), C-240 (Ionac), or 
Amberlite IR-120 (Rohm \& Haas); the anion could be Duolite A-101D, Dowex 1, Ionac A-540 or Amberlite IRA-402. The nominal mesh size is 30-50. For consistency, it would be worthwhile to purchase resins and fabricate columns. Since the direction of flow through the column is upward, a finer mesh size could be tolerated for better polishing.

\subsubsection{Instrument Stability and Sensitivity Testing}

The systems were run for approximately 1 month on laboratory demineralized water, from the same outlet. Chloride levels, ranged from 1 to $4 \mathrm{ppb}$, sodium from 0.4 to $1.0 \mathrm{ppb}$. Long-term stability under steady-state conditions appeared excellent. The manufacturer recommends that the diffusion tubing (silicone rubber) in the chloride monitor be replaced on a biweekly basis, owing to short-term degradation from external contact with formic acid; the same tubing which is used in the sodium monitor has a quoted longevity of 6 months.

The range of the received chloride monitor was 0 t.o $50 \mathrm{ppb}$ (1inear scale). This was contradictory to the range specified on the purchase order ( 0 to $250 \mathrm{ppb})$. Orion has agreed to retrofit the electronics to give us the desired range.

Response time for the chloride monitor is excellent. Full range upscale response is $10 \mathrm{sec}$ at a flow rate of $40 \mathrm{ml} / \mathrm{min}$; downscale response is about $30 \mathrm{sec}$. The sodium monitor is somewhat worse (10 min full downscale response for complete recovery, equivalent upscale response time). On both, a lag time of $45 \mathrm{sec}$ is observed from the time the sample first enters the system at a flow rate of $40 \mathrm{ml} / \mathrm{min}$.

A second series of calibration data for the chloride monitor was generated in the following manner: A stock solution (2325 $\mathrm{ppb} \mathrm{Cl^{- }}$ ) was injected into the polished dilutant $\left(0 \mathrm{ppb} \mathrm{Cl^{- }}\right)$ at four constant flow races $(0.35,0.43,0.52$, $0.70 \mathrm{~m} / \mathrm{min}$ ). When the dilutant flow rate was $40 \mathrm{~m} / \mathrm{min}$, the corresponding concentrations were $20,25,30$, and $40 \mathrm{ppb} \mathrm{Cl}^{-}$, respectively. Increasing/ decreasing the flow rate of the dilutant would therefore decrease/increase the 
chloride concentration when the injection rate is held constant. The. theoretical concentrations for these experiments can be derived from the following equation.

$$
\frac{\mathrm{f}_{d \mathrm{C}_{\mathrm{d}}}+\mathrm{f}_{i} \mathrm{C}_{i}}{\mathrm{f}_{\mathrm{d}}+\mathrm{f}_{i}}=\mathrm{C}_{\mathrm{Cl}}-
$$

where

$$
\begin{aligned}
& f \text { is flow rate } \\
& C \text { is concentration }
\end{aligned}
$$

Subscript $i$ is injectant

Subscript d is diluent

The manufacturers recommended diluent (sample) flow rate is $40 \mathrm{~m} l / \mathrm{min}$. The results for various $\mathrm{NaCl}$ concentrations and sample flow rates are given in Table 3-27 and Figure 3-20.

In most cases, the agreement between the observed and calculated values is reasonable when the flow rate is maintained close to the manufacturer' $\varepsilon$ recommended value. Deviations are, however, substantially greater when the flow rate and/or concentration is lower. This was confirmed with another experiment. The monitor was calibrated, and the concentration of laboratory demineralized water measured as a function of sample flow rate. Readings. were recorded 5 min after adjustment. The data are shown in Figure 3-20 with the data from the sodium monitor. While the sodium analyzer showed neglibible ( $1 f$ any) response to changes in flow rate from 35 to $50 \mathrm{ml} / \mathrm{min}$, the chloride monitor gave large variations depicting an inverse parabolic correlation between the two parameters. A significant improvement on the flow regulation system is sorely needed if meaningful data are to be obtained in the vicinity of 0 to $5 \mathrm{ppb}$. 
Table 3-27

CHLORIDE MONITOR PERFORMANCE

Flow Rate

Injectant
Diluent

$\mathrm{ml} / \mathrm{min}$
Chloride Concentration (ppb)

Calculated

Measured

$\begin{array}{llcc}0.70 & 45 & 36 & 36 \\ 0.70 & 40 & 40 & 40 \\ 0.70 & 36 & 44 & 42 \\ 0.70 & 30 & 53 & \text { off scale } \\ 0.52 & 45 & 26 & 26 \\ 0.52 & 40 & 30 & 30 \\ 0.52 & 36 & 33 & 33 \\ 0.52 & 30 & 40 & 39 \\ 0.43 & 50 & 20 & 20 \\ 0.43 & 45 & 22 & 23 \\ 0.43 & 40 & 25 & 25 \\ 0.43 & 35 & 28 & 36 \\ 0.43 & 30 & 33 & 38 \\ 0.43 & 25 & 40 & \text { off scale } \\ 0.43 & 20 & 49 & \text { off scale } \\ 0.35 & 45 & 18 & 14 \\ 0.35 & 40 & 20 & 20 \\ 0.35 & 36 & 22 & 29 \\ 0.35 & 30 & 27 & 16\end{array}$

Various substances were injected into the analyzer inlets to observe chemical transient responses at base line levels. While $2 \mathrm{ml}$ of concentrated ammonia caused the chloride monitor to go off scale high (chloride impurity or $\mathrm{OH}^{-}$ response), the sodium monitor remained unchanged. This is important in that the condenser leak can be detected during a major ammonia transient. The injection of $2 \mathrm{ml}$. $1 \mathrm{M} \mathrm{HNO}_{3}$ caused the sodium monitor to go off scale high, while the chloride monitor drifted slightly upward. Air injections caused the flow rate in both systems to decrease, yielding the expected positive response in the chloride monitor. The sodium analyzer was not affected. 

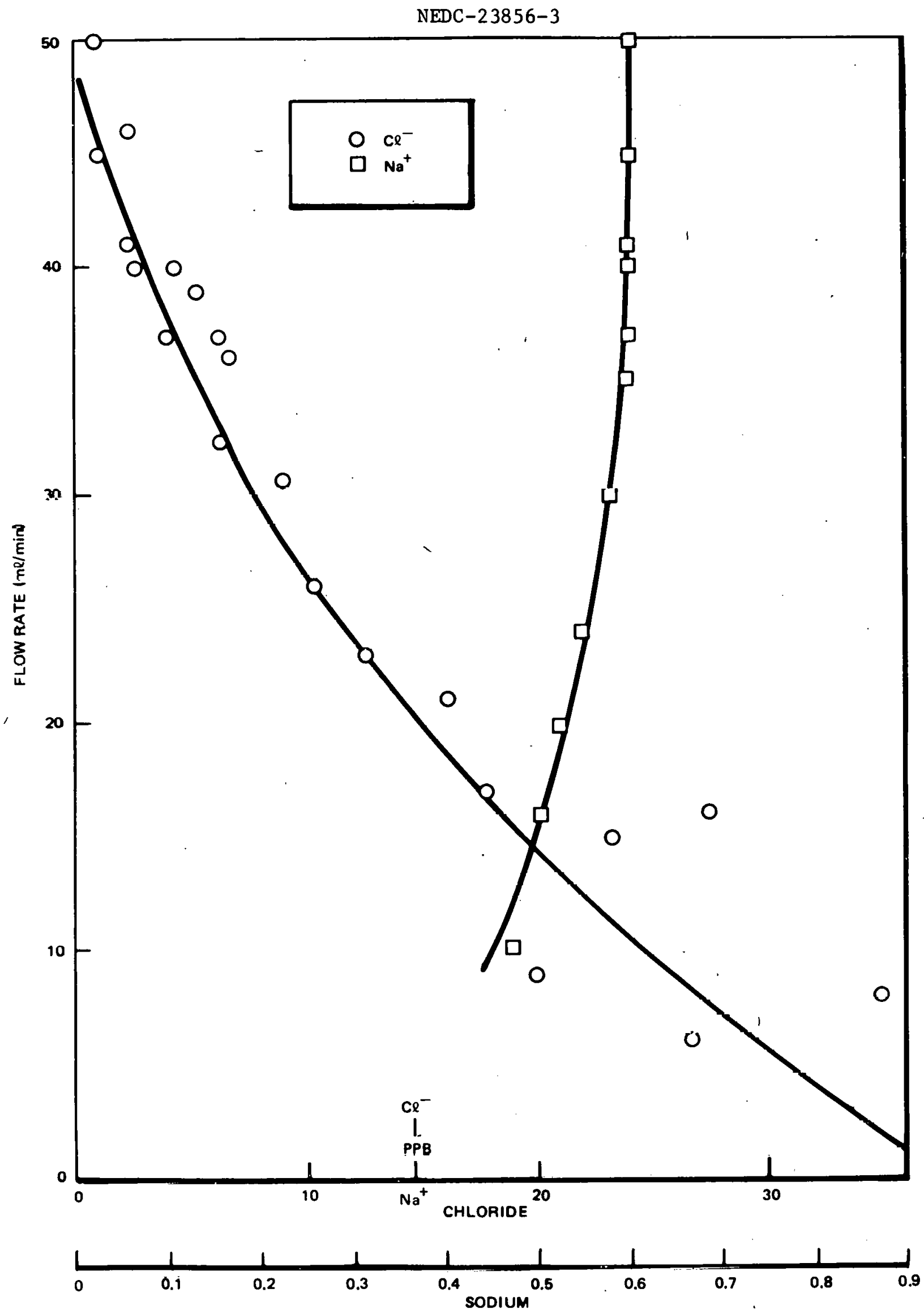

Figure 3-20. Chloride and Sodium Monitor Variation With Sample Flow. Kate

3-62 


\subsubsection{System Modifications}

In addition to improvement of the flow regulation system on the chloride monitor a transparent cooling water housing which jackets the electrode chamber should be added. The unit does not permit an inspection for entrapped air/steam bubbles in the vicinity of the electrode tip without complete disassembly. Since bubbles can only be unfavorable to the system, this retrofit is essential.

The maximum sample temperature the sodium monitor can tolerate is $50^{\circ} \mathrm{C}$. Above this temperature, the compensation circuitry is not linear. The cooling water bath for the chloride monitor does not have sufficient capacity to handle an '. incoming stream whose temperature is greater than $45^{\circ} \mathrm{C}$. Thus, larger sample coolers, similar to those employed for corrosion product sampling, are required for both systems. If and when the units are, on line in a power plant, strict attention must be given to the cooling water supply. If cooling water is shut off, inadvertently or otherwise, the electrodes may be irretrievably damaged.

The chloride analyzer evaluation cannot be completed until an electronic retrofit which yields 0 to $250 \mathrm{ppb}$ full scale is obtained. The sodium monitor appears to be ready for use in a power plant if the following. minor design changes (which are also recommended for the chloride monitor) are made:

a. Improve the sample rotameter,

b. Improve the pressure regulator,

c. Replace the flow control valve,

d. Introduce a flow transducer upstream of the rotameter,

e. Have a multipoint recorder or data acquisition system available to monitor concentration, temperature and flow rate,

f. Filter and process stream prior to the sodium or chloride monitor inlet, and

g. Introduce a thermistor in the analyzer diail lines. 


\subsection{TASK B-4. PLANT MATERIALS COMPATIBILITY (B. M. Gordon)}

Objective. A primary concern in the application of an AWC to the BWR is the possibility of materials-coolant incompatibilities which might be introduced. This task, in addition to evaluating the necessary and limiting additive and oxygen concentrations necessary to mitigate stress-corrosion cracking tendencies in the primary coolant loops, will investigate the general corrosion behavior of normally encountered BWR materials in the proposed additive chemistry environment.

The tests in the program are specifically designed to not only demonstrate that the various AWC's do indeed prevent stress-corrosion cracking of typical BWR structural materials, but also do not in thenselves produce any detrimental or unacceptable corrosion problems.

\subsubsection{Constant Extension Rate Tests (F. P. Ford, Corporate Research and Development Center, Schenectady, N.Y.)}

The effect on the stress-corrosion susceptibility of sensitized Type-304 stainless steel of adding $20 \mathrm{ppm}$ ammonia to $\mathrm{BWR}$ quality water at $288^{\circ} \mathrm{C}$ has been evaluated for various oxygen-levels in the water.

The evaluation was made by the CERT technique at a strain rate of $1.3 \times 10^{-4}$ minute ${ }^{-1}$, the cracking response being measured in terms of a "maximum" crack-propagation rate defined by [maximum observed crack penetration/test time], as discussed previously. ${ }^{1}$ This method of evaluatinn and prosontation is preferred over the standard technique of comparison of ductility parameters (elungation, reduction in area etc.), especially when attempting to distinguish between small differences in stress-corrosion susceptibility.

The results are tabulated in Table $3-28$ and are shown in Figure 3-21 for initially smooth specimens and in Figure 3-22 for notched specimens. 
Table 3-28

EFFECT OF AMMONIA ON STRESS CORROSION CRACKING OF TYPE-304 STAINLESS STEEL AT $288^{\circ} \mathrm{C}$

\begin{tabular}{|c|c|c|c|c|c|c|c|c|}
\hline Specimen & $\begin{array}{c}\text { YS } \\
\text { (ksi) }\end{array}$ & $\begin{array}{l}\text { UTS } \\
\text { (ksi) }\end{array}$ & $\% \mathrm{RA}$ & $\begin{array}{l}\text { Maximum Crack } \\
\text { Penetration } \\
\text { (in.) }\end{array}$ & $\begin{array}{l}\mathrm{O}_{2} \\
(\mathrm{ppm})\end{array}$ & $\begin{array}{c}\mathrm{NH}_{4}^{+} \\
(\mathrm{ppm})\end{array}$ & $\begin{array}{l}\text { Test } \\
\text { Time } \\
\text { (hr) }\end{array}$ & $\begin{array}{l}\text { Velocity } \\
\text { (mils/day) }\end{array}$ \\
\hline
\end{tabular}

\section{(a) Smooth Specimens}

\section{Argon}

$1 \mathrm{~A} 1$

$22.25 \quad 73.00 \quad 67$

$0.2 \mathrm{ppm} \mathrm{O}_{2}$ Nominal

1A3
1B2
1B3

$20.00 \quad 69.00 .36$

19.39

73.10

$0.033 \mathrm{I} / \mathrm{G}-\mathrm{T} / \mathrm{G}$

$21.44 \quad 70.86 \quad 55$

0.006

$0.2 \quad / 0.25$

$0.020 \mathrm{I} / \mathrm{G}-\mathrm{T} / \mathrm{G}$

$0.16 / 0.17$

$0.01 \mathrm{ppm} \mathrm{O}_{2}$ Nomina

$\begin{array}{ll}\hat{\vdots} & 1 \mathrm{~A} 4 \\ & 1 \mathrm{~A} 18 \\ & 1 \mathrm{~B} 1 \\ & 1 \mathrm{~B} 4\end{array}$

$\begin{array}{lll}19.50 & 71.00 & 54.0 \\ 19.00 & 70.40 & 59.0 \\ 19.04 & 71.17 & 57.0 \\ 17.10 & 71.60 & 55.0\end{array}$

0.017

0.018

0.009

$T / G$

$0.02 / 0.025$

0.012

$0.001 / 0.005$

0.003

$0.003 / 0.036$

$T / G$

(b) Notched (0.013 in. depth) Specimens

Argon

$1 \mathrm{A5} \quad \cdot 23.10 \quad 80.0 \quad 46$

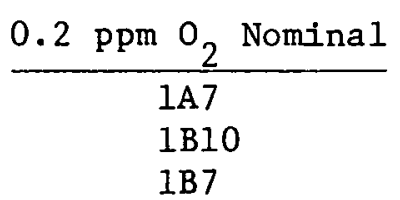

$\begin{array}{lll}23.71 & 66.87 & 27 \\ 22.36 & 72.27 & 34 \\ 20.54 & 62.60 & 26\end{array}$

$0.029 \mathrm{I} / \mathrm{G}-\mathrm{T} / \mathrm{G}$

$0.029 \mathrm{I} / \mathrm{G}-\mathrm{T} / \mathrm{G}$

$0.047 \mathrm{I} / \mathrm{G}$

$0.15 / 0.2$

0.2

$0.16 / 0.17$

$--$

30.41

53.5

77.1

14.8

20.7

61.0

1.85

7.86

$\frac{0.05 \mathrm{ppm} \mathrm{O}_{2} \text { Nominal }}{1 \mathrm{~B} 9}$

$1 \mathrm{~B} 6$

$\begin{array}{lll}29.18 & 77.64 & 29\end{array}$

$0.021 \mathrm{I} / \mathrm{G}-\mathrm{T} / \mathrm{G}$

0.074

$0.030 \mathrm{I} / \mathrm{G}-\mathrm{T} / \mathrm{G}$

0.07

22.3

32.25

6.0

$--\quad 70.5$

71.1

-- 72.9

6.1

2.9

3.8

$0.01 \mathrm{ppm} \mathrm{O}_{2}$ Neminal

$1 \mathrm{~A} 8$

23.10

77.94

18.11

22.10

66.04

74.40

0.005

T/G

0.025

0.011

0.009

$0.004 / 0.006$

42.2

44.1

44.3 


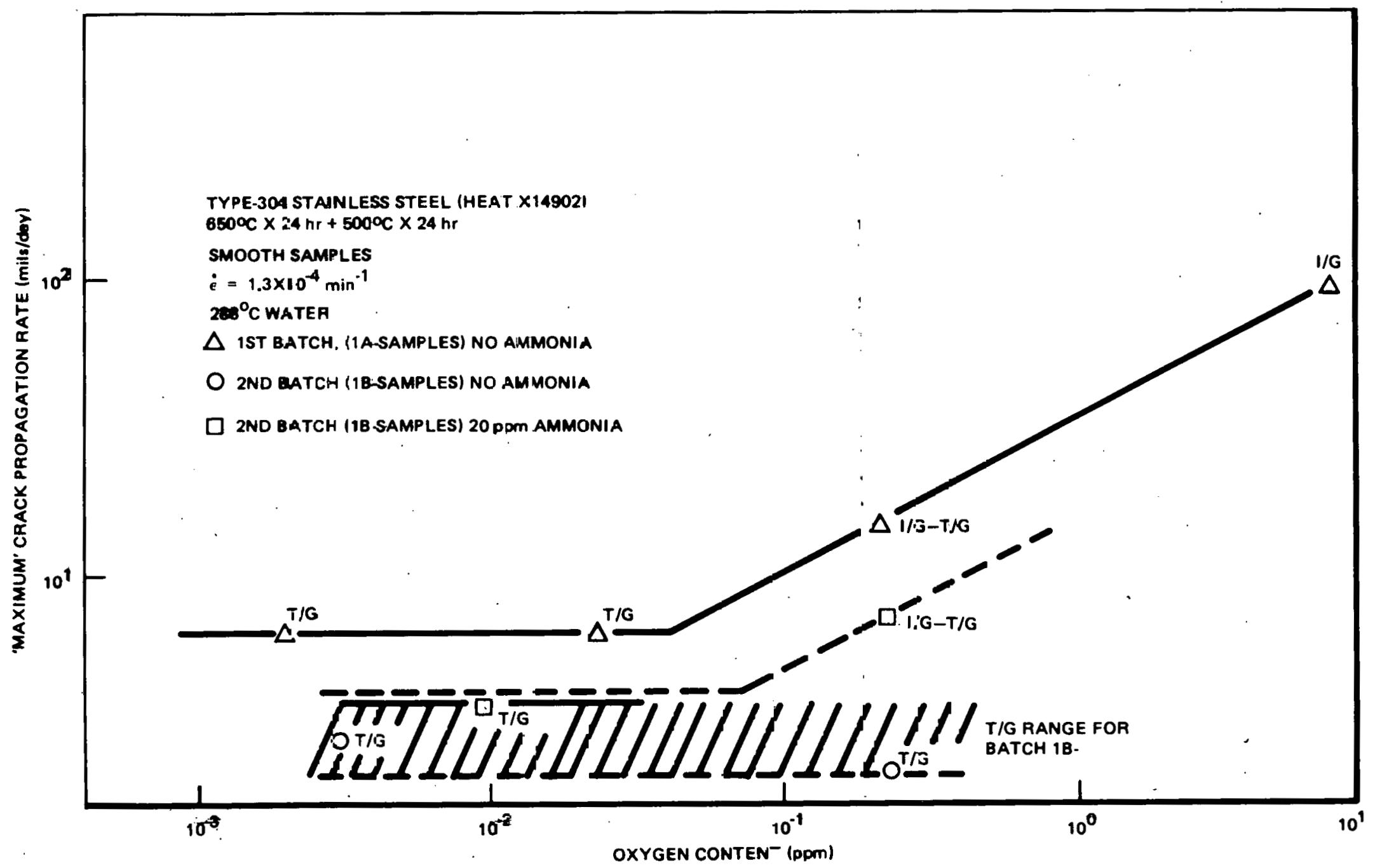

Figure 3-21. Crazk Propagation. Rate versus Oxygen Content for Smosth Samples 


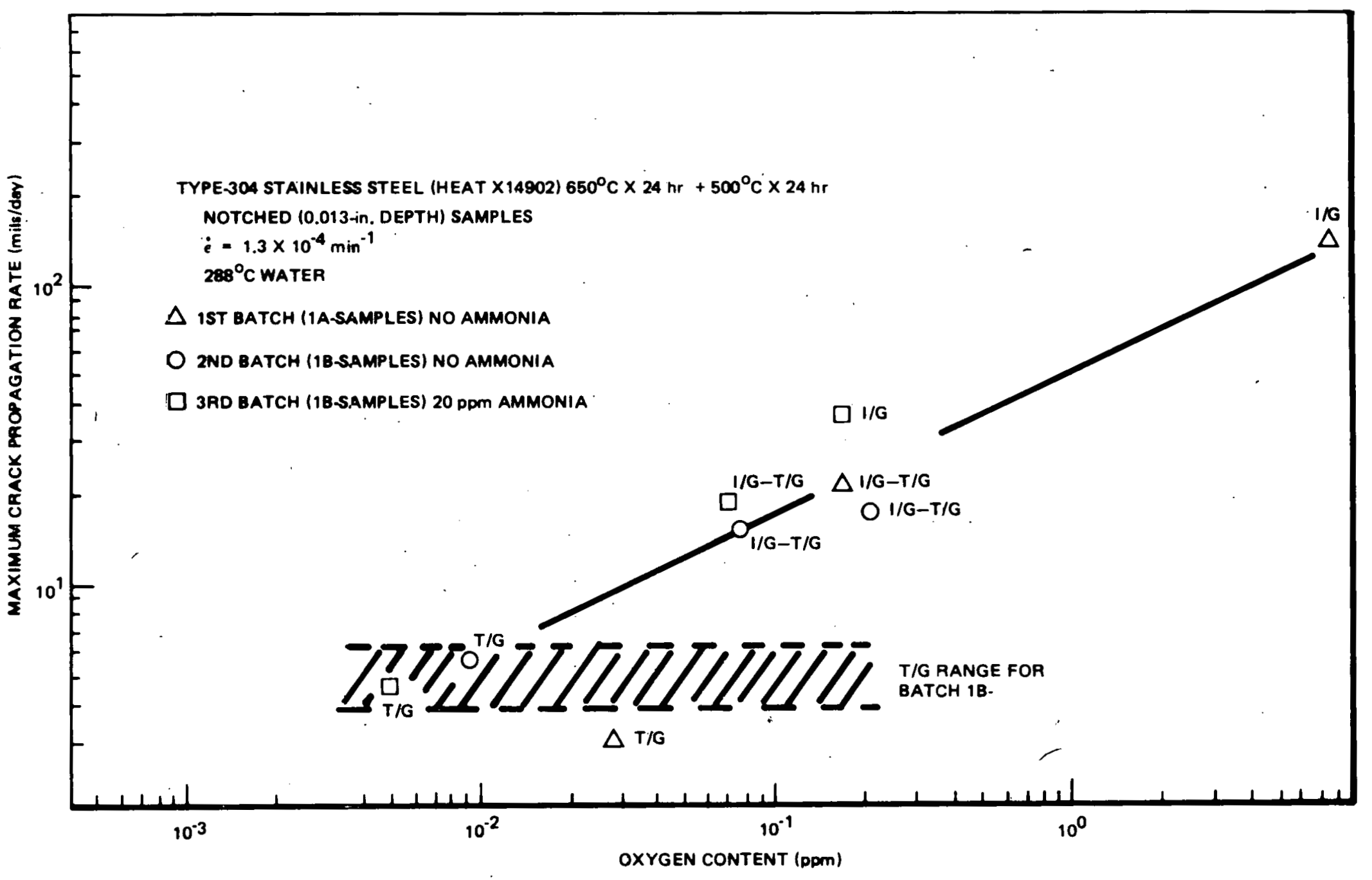

Figure 3-22. Crack Propagation Rate versus Oxygen Content for Notched Samples 
The conclusions are:

a. There is a difference in results, for those tests without ammonia addition, between those specimens prefixed $1 \mathrm{~A}$ and those prefixed $1 \mathrm{~B}$. (These batches were heat-treated, nominally under the same conditions, but at different times;) This difference in results in most marked on the initially smooth specimens (Figure 1) and is most likely related to an alteration in the ease of crack nucleation; note, for instance, that in the $0.2 \mathrm{ppm}$ oxygen solution I/G cracking was not inilialed In the 1B series (Specimen 1B2), whereas it was in the $1 \mathrm{~A}$ series (Specimen l.A.3). As expected, therc was not such a marked difference in behavior between the two batches using prenotched samples (Figure 3-22), when cliemlcal crack nücleation modes (which could be dependent on minor variations in heat treatment) are superseded by mechanical crack nucleation modes.

b. The maximum I/G crack propagation rate decreases with decreasing oxygen content, the crack morphology changing from $I / G$ to $T / G$. As noted above, however, there is a considerable oxygen range over which this morphology change takes place, and this may also be a function of minor variations in heat treatment. The $T / G$ crack propagation rate is essent.1.11.y independent of oxygen content. At a given orygen content, the ease of $T / G$ crack nucleation is easier (see second quarterly report) than I/G cracking, but the crack propagation rates are considerably lower (c.f. 1D2 with 1B3).

c. The effect of ammonia was investigated using the 1 B seriog of samples. There is not a major effect of ammonia content (20 ppm) on crack-propagation rate for a given crack morphology. e.g., compare 1B4 with $1 B 1$ and $1 B 2$ for $T / G$ cracking on smooth specimens, and 185 with $1 B 8$ for prenotched specimens. Any difference detected in the mixed-mode cracking range circa $0.2 \mathrm{ppm} \mathrm{O}_{2}$ can be related to the different amounts of slow $T / G$ and fast $I / G$ cracking. For instance, the higher propagation rates for $1 \mathrm{~B} 7\left(20 \mathrm{ppm} \mathrm{NH}_{4}^{+}\right)$compared 
NEDC-23856-3

with $1 B 10$ (no ammonia) can be related to the higher percentage of I/G cracking in the former case; a similar explanation can be given for the higher propagation rate of $1 \mathrm{~B} 3$ with respect to $1 \mathrm{~B} 2$. It is unclear at' this stage whether ammonia really promotes the faster I/G cracking mode (i.e., there are insufficient data to make such a positive claim), but in the situation where only I/G SCC is observed in practice (e.g., BWR operations), it would be reasonable to conclude that ammonia additions do not have a significant effect on crack propagation rates.

\subsubsection{Hydrogen Addition Tests}

Work is presently concentrated on Tests $1 \mathrm{~B} 11$ - 1B13, i.e., the effect of $0.2 \mathrm{ppm}$ $\mathrm{H}_{2}$ addition to various oxygen-containing solutions on the SCC of sensitized Type-304. Difficulties persist in the attempt to satisfactorily analyze the dissolved hydrogen content; the present problem being the continual mechanical breakdown of the gas-sampling recirculation pump.

\subsubsection{Straining Electrode Tests (M. Indig)}

A series of SET to determine the effects of dissolved oxygen and hydrogen (potential) on the IGSCC susceptibility of an extremely susceptible heat of Type-304 (Heat No. M7616) has been completed. A detailed description of the test has been discussed previously, ${ }^{1,18}$ and thus only a brief summary of the test background is presented here.

The SET as presented in Figure 3-23, is a CERT of an electrically insulated tensile specimen which is maintained at a fixed electrochemical potential. In all but one of the test environments the test electrolyte was a nitrogen deaerated $0.01 \mathrm{~N} \mathrm{Na}_{2} \mathrm{SO}_{4}$ solution. The tests were conducted at $274^{\circ} \mathrm{C}\left(525^{\circ} \mathrm{F}\right)$ where the SET was initiated by first applying a constant extension rate of $0.0025 \mathrm{~cm} / \mathrm{h}(0.01 \mathrm{in} / \mathrm{h})$ and then by fixing the potential of the tensile specimen. The above strain rate is approximately $2 \times 10^{-5} \min ^{-1}$. The autoclave system is illustrated in Figure 3-24. 


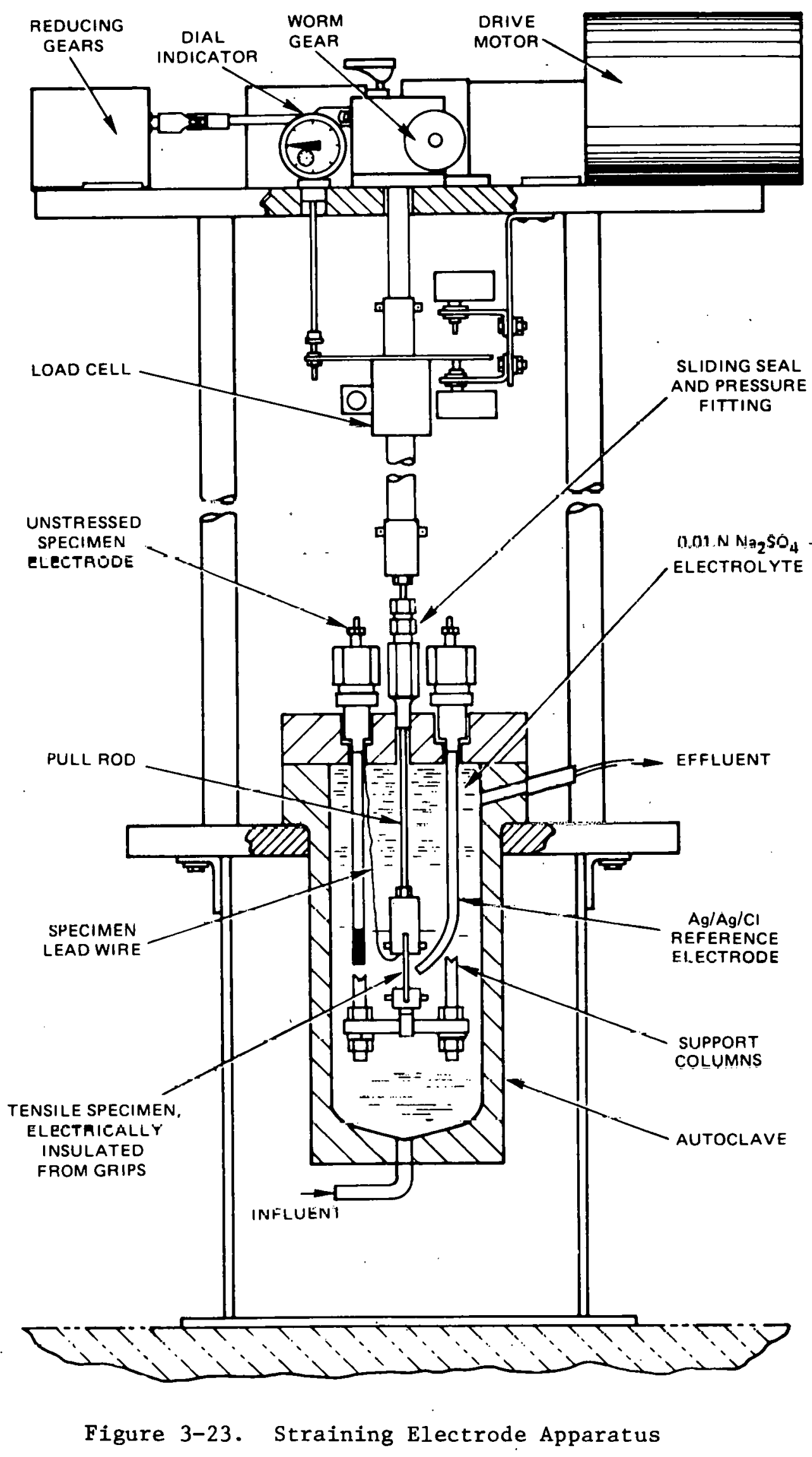




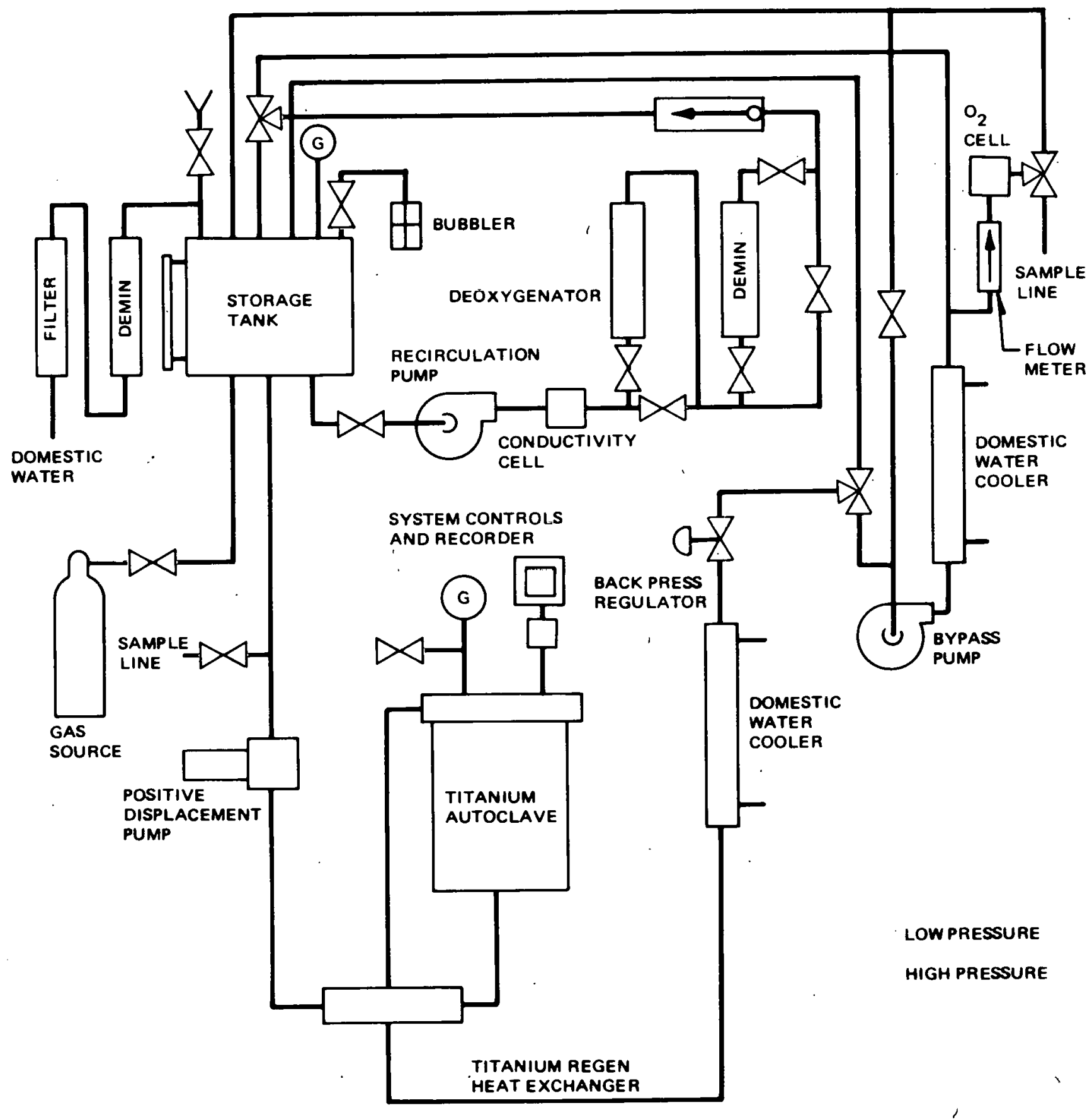

Figure 3-24. Refreshed Water Loop for Electrochemical Studies 
The resistance of a highly susceptible heat of material was evaluated in SET's at $274^{\circ} \mathrm{C}$ and (with the exception of one run) in $0.01 \underline{\mathrm{N} \mathrm{Na}} \mathrm{SO}_{4} \cdot$ "As-welded $(w)$ and "as-welded-plus-low-temperature-sensitized" (W+LTS) conditions were tested at varying potential and with and without hydrogen addition.

The results are presented in Table 3-29. They are ranked according to increasing resistance to IGSCC with the hydrogen gas studies at the bottom (most resistant). The parameters used in ranking the specimens resistance to IGSCC are typical mechanical factors such as time to failure, reduction of area, percent elongation and mode of failure.

Table 3-29 shows that as the potential in we1ded stainless steel is reduced, the susceptibility to IGSCC decreases. An electrochemiral potential of. $-U .40 U V_{\text {SHE }}$ appears to mitigate IGSCC of as-welded Type-304. When the specimen receives an additional LTS treatment, severe IGSCC occurred at $-0.400 \mathrm{~V}_{\mathrm{SHE}} \cdot$ Dropping the potential an additional. $0.050 \mathrm{~V}_{\mathrm{SHE}}$ produced only a slight improvement in the IGSCC response. However, when the potential is reduced to a level which simulates the presence of hydrogen $\left(-0.750 \mathrm{~V}_{\mathrm{SHE}}\right)$ the results are dramatically different. The cathodic potential is the electrochemical equivalent of approximately $4 \mathrm{ppm}$ dissolved hydrogen at $274^{\circ} \mathrm{C}$ and produced ductile failure with only minor amounts of transgranular cracking. Since annealed stainless steel exhibits some TGSCC under the same test conditions, TGBCC, per se, does not warrant particular engineering consideration.

A similar experiment was conducted in the same $0.01 \mathrm{~N} \mathrm{Na}_{2} \mathrm{SO}_{4}$ electrolyte where the potential was controlled hy the direst addition of hydrugeu Lu Llie system rather than electrochemical control with a potentiostat. The results of this study were characterized by similar mechanical property values as produced in the prior test where hydrogen was only simulated. The time to failure (206 versus $216 \mathrm{hr}$ ), reduction of ared (28.6 versus $26.6 \%$ ) and elongation valves (14.9 versus $13.6 \%$ ) are essentially the same for the hydrogen gas and hydrogen simulation studies, respectively. The specimen in the hydrogen gas test was characterized by a fracture morphology of severe surface TGSCC with some minor IGSCC penetrations at the tips of the microfissures. The specimen overall failure mode was over $90 \%$ ductile. 
Table 3-29

STRAINING ELECTRODE RESULTS FOR WELDED TYPE-304 STAINLESS STEEL (HEAT NO. 1) AT $274^{\circ} \mathrm{C}$ in $0.1 \mathrm{~N} \mathrm{Na} 2^{\mathrm{SO}} 4$ (Strain Rate of $2 \times 10^{-5} \mathrm{~min}^{-1}$ )

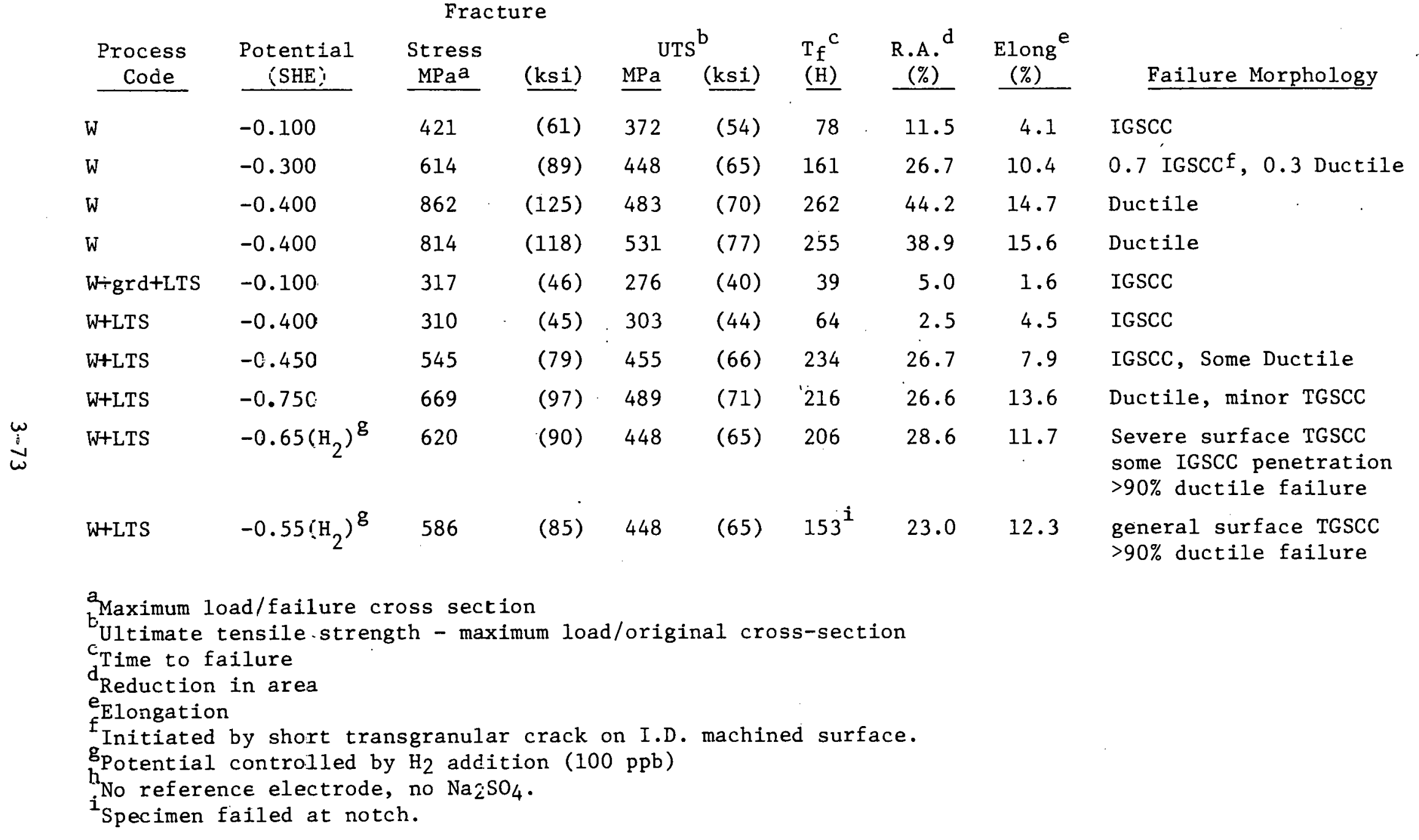


A third hydrogen experiment was performed in pure water, without $\mathrm{Na}_{2} \mathrm{SO}_{4}$, so that the effect of this substance, if any, could be evaluated. Also, no reference electrode was used to discount any effect of this item in the test series. Here again the mechanical properties were similar to the two other hydrogen experiments with the exception of a slight premature failure of the specimen due to a small unintensional notch along the gauge length. As expected, the failure which was also characterized by over $90 \%$ ductile failure occurred at this surface irregularity.

Therefore, the post-test examination of Lliese three hydrogen SET tests (one simulated, two actual hydrogen addillons) reveal that the specimens failed by ductile rupture, coalescence of microvoids, with only minor indications of IGSCC penetrations on one specimen. Transgranular cracks did uccur on a $\perp$ surfaces and were often associated with surface discontinuties and cold worked areas, such as machining grooves on the i.d. section of the pipe from which specimens were fabricated. Previous studies in several laboratories have indicated that these transgranular cracks can be expected to occur in CERT or SET testing techniques. These cracks require considerable strain to initiate (approximately $10 \%$ ) and have no engineering significance. ${ }^{18}$ 


\subsection{TASK B-5. DEMINERALIZER PERFORMANCE (W. L. Lewis, L. L. Sundberg)}

Objective. Current BWR practice is to use hydrogen form (i.e., acid regenerated) cation exchange resins for the bypass clean-up system and the full-flow condensate demineralizers. This practice can be continued when using hydrogen as the oxygen-suppressing additive. The use of dissociating additives such as ammonia or hydrazine however, dictates the use of an ammonia-based cation resin. Use of such ammonia-form resins instead of the acid form causes significant deterioration of all aspects of resin performance.

This task is designed to define the ion-exchange systems necessary to permit operation with the ammonia additive and to determine exactly what performance penalties will be incurred with such a system.

\subsubsection{Performance Predictions}

A series of calculations has been performed ${ }^{18}$ to determine the effects of additives upon the. BWR water treatment systems. The only additive with no apparent deleterious effects upon the ion-exchange resins is hydrogen. The other two additives considered, ammonia and hydrazine, affected the Condensate and Reactor Water Clean-Up Treatment Systems to such a degree that satisfactory operation with other than minor condenser seepage is highly unlikely. The latter two additives increase the $\mathrm{pH}$ of the feedwater and reactor water and reduce the exchange capabilities and capacities of the cation and anion resin beds. Of particular concern is the decreased sodium exchange capability of the cation resin in the condensate treatment system with high concentrations of ammonia. Addjtional effects of operation with hydrazine or ammonia which must be considered are the exacting physical separation requirements of the resins in deep bed regeneration systems and, the necessity for an increased volume of chemicals for regeneration. Of interest; also, is the requirement for high purity in the regeneration chemicals. Due to the alkaline properties of the condensate stream, a high level of regenerated sites is required for the ion-exchange resins, and a minimum amount of impurities in the regenerating stream can be tolerated. 
In short, the penalties associated with the use of ammonia or amine additives are so severe they may well preclude further consideration of these additives as viable alternatives.

\subsubsection{Resin Testing}

Because of the critical impact the use of ammonia-based resins at high $\mathrm{pH}$ has on the ultimate additive selection, preparations are being made to actually test and compare resin performance in a San Jose test facility.

A schematic diagram of the test loop is presented in Figure 3-25. The suction side of the 10 horsepower feed pump is connected to a 150-gal, cylindrical, covored otorage taik. The pump w1ll discharge $51 \mathrm{gpm}$ at $60 \mathrm{psig.} \mathrm{This} \mathrm{feed}$ stream may be partitioned between three deep-bed columns or two filterdemineralizers or combinations of the five vessels providing total flow does not exceed the $51 \mathrm{gpm}$ limitation.

Demineralizer inlet and return lines are 2-in. Schedule-40 polyvinyl chloride (PVC) pipe. The inlet header and each vessel outlet line contain taps for 1/4-in. sample 11nes.

Makewup into the surge tank is regulated by higl and low level control switches with a vertical differential of about 1 in. Make-up demineralized water from the building supply is polished in a 3-in.-diam x 36-in. high chemically equivalent ion-exchange bed before entering the surge tank. The surge tank is cooled by a heat exchange coil. containing $80 \mathrm{ft}$ of $1 / 2-i n$. stainless steel tubing using building service water to maintain the surge tank tompcrature at $80^{\circ} \mathrm{F}$.

Two tanks of $50 l$ each are used for additive injection--one for $\mathrm{NH}_{3}$, the other for $\mathrm{NaCl}-\mathrm{Fe}_{2} \mathrm{O}_{3}$. Two methods for additive addition were used. In the first, a Milton-Roy Mini Pump $B$ was employed. on each addition tank. The injection rate was typically $10 \mathrm{~m} \ell / \mathrm{min}$. One-eighth-inch stainless steel lines were run from the injection pump discharge to the top of the surge tank. The second method used two relays to control the open and closed times of a solenoid valve 


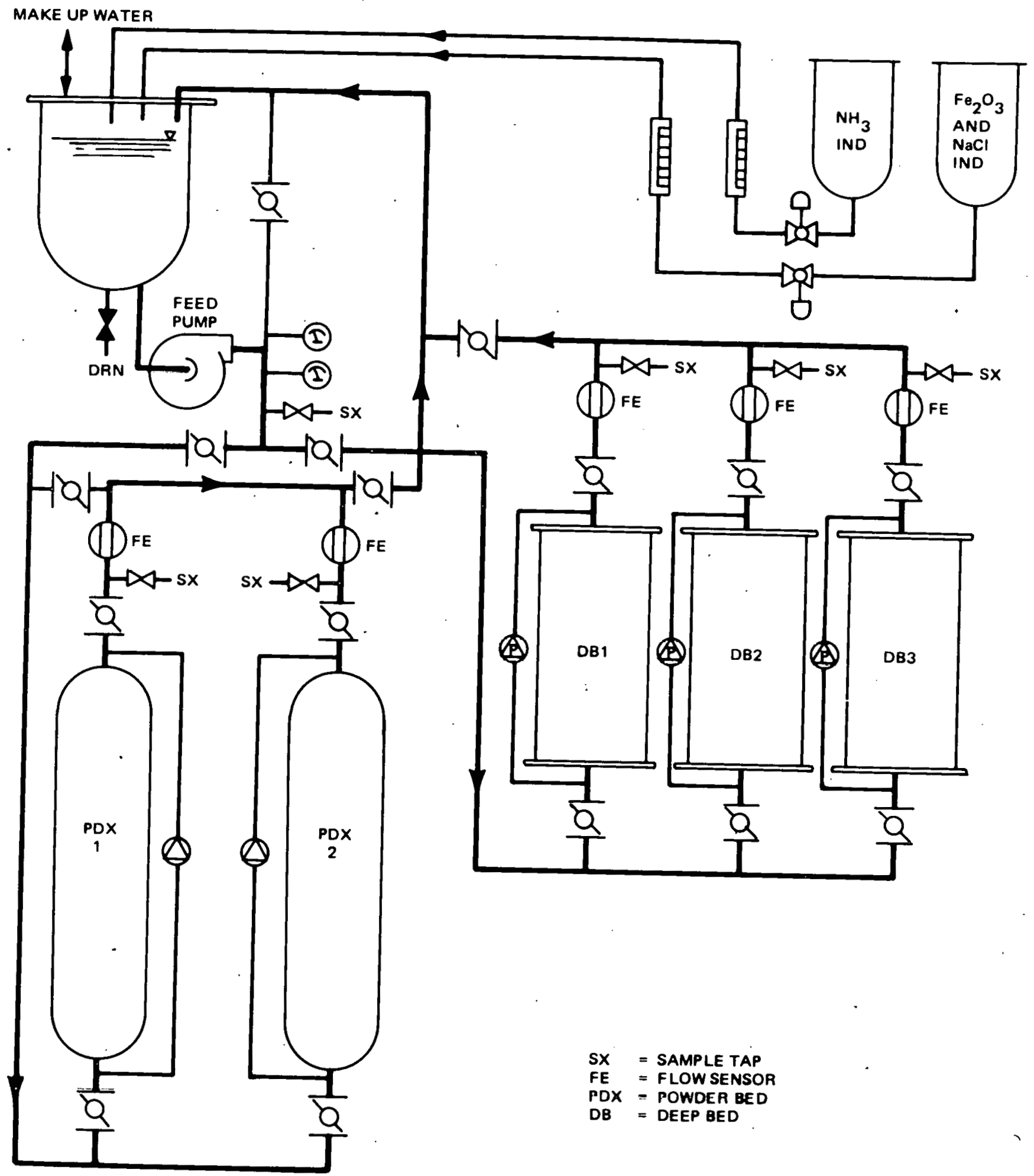

Figure 3-25. Resin Test System 
between the addition and surge tanks. The addition tanks were pressurized to 5 psig with helium in this system to force the liquid into the surge tank.

The deep bed resin columns are 8 -in. Schedule-40 PVC pipe. The nominal bed height is $3 \mathrm{ft}$, yielding an active resin volume of roughly $9 \ell$. A 100-mesh stainless steel underscreen is clamped between the bottom flange sections of each vessel.

Bead resins were obtained from Bio Rad Laboratories, Richmond, Califorsia, and were ordered under the acceptance criterfa of GE Purchase Specification $21 \mathrm{~A} 8844$.

Prior to the test runs, these resins were washed with 5 column volumes of deilintedized wacer through loll-mesh screen. This practice removed lhe leachable organics and resin fines. Without the wash the fines plugged the resin underdrains. The columns were loaded in 5-1iter inrroments with tho appropriate cation/anion ratio to minimize bed stratification. When all the resin was loaded, the columns were gently backwashed to remove air pockets. Column flow rates are measured upstream of the return header with FisherPorter Model 10A1027 flow meters with stainless steel floats.

\subsubsection{Analytical Systems}

\subsubsection{Conductivity}

Balsbaugh Series 910 conductivity monitors and cells will be used throughout this investigation. Cell constants are 0.01 or $0.1 \mathrm{CM}^{-1}$ depending on the magnitude of the conductivity. Readings will be taken from the inlet header and each vessel outlet (typically) on an hourly basis. The effluent from each cell flows to a 1 I/2-in. $x 18$ in. PVC column of cation exchange resin (Dowex $50 \times 8,20-50$ mesh, $H^{l \cdot}$ form) and then to a second conductivity cell. Thus, yielding the "acid conductivity" of each stream. The flow rate through each conductivity cell is $300 \mathrm{ml} / \mathrm{min}$. Each cell and accompanying meter is placed in serfes periodically with a common feed stream to ensure the same reading after cross-calibration with a Beckman Model BB-1 ip cell. Output data are recorded on a 30-channel Leeds and Northrup Speedomatic recorder. 


\subsubsection{Sodium}

Sodium ion concentrations were monitored by ion-selective electrodes (Subsection 3.4) using an Orion Model 151102 "a/sled" (absolute sodium leak detector). In this system, sample water flows through $4 \mathrm{ft}$ of silicone rubber tubing which is immersed in ammonia liquor. Gas phase diffusion of ammonia into the sample raises the solution $\mathrm{pH}$, thereby decreasing the system response to hydrogen ion. The system exhibited Nernstian behavior from 0.1 to $1000 \mathrm{ppb} \mathrm{Na}^{+}$. Sample flow rate will be $40 \mathrm{ml} / \mathrm{min}$. Sample water is filtered with a $0.45 \mu \mathrm{m}$ Millipore (R) filter to prevent the formation of $\mathrm{Fe}_{2} \mathrm{O}_{3}$ films on the electrodes. The system is calibrated on a weekly basis per the manufacturer's recommendations using a Sage Instruments Model 355 syringe pump with UBS SRM 2201 as a working standard. Since only one unit is available, it is only possible to monitor one stream at a time.

\subsubsection{Chloride}

Chloride ion will be monitored with the prototype instrument from Orion Laboratories described in Subsection 3.4. Again the measurement principle is based on selective ion electrodes. Here the sample water passes through silicon rubber diffusion tubing that is immersed in $88 \%$ formic acid. Gas phase diffusion of formic acid into the sample lowers the $\mathrm{pH}$, thereby decreasing the electrode response to hydroxide ion. In addition, the sample is cooled to $4^{\circ} \mathrm{C}$ to attain the desired sensitivity of the determination ( 0 to $50 \mathrm{ppb} \mathrm{Cl}^{-}$). Cooling was accomplished with a Neslab TE-8 refrigerated bath circulator. Calibration procedures are identical to those for the sodium analyzer. Filtered sample flow rates are $40 \mathrm{~m} \ell / \mathrm{min}$, again with the restriction of analyzing only one stream at a time. 


\subsubsection{Test Plan}

When the loop instrumentation is completed the following runs will be made:

Test 1

$$
\text { Cation Resin Resin Ratio Flow, Gpm/ft }{ }^{2}
$$

Resin Beds: Deep Bed 1

$\mathrm{NH}_{4}$

$2: 1$

50

Deep Bed 2

$\mathrm{NH}_{4}$

$1: 1.3$

50

Deep Bed 3

$\mathrm{H}^{+}$

$1: 1.3$

50

Feed Solution: $\mathrm{Na}^{+}-200 \mathrm{ppb}$

$$
\begin{aligned}
& \mathrm{Cl}-300 \mathrm{ppb} \\
& \mathrm{Fe}_{2} \mathrm{O}_{3}-200 \mathrm{ppb} \\
& \mathrm{NH}_{3}: \text { Test } 1 \text { Zero }(\mathrm{pH} \sim 7)
\end{aligned}
$$

\begin{tabular}{|c|c|c|c|c|}
\hline \multirow{4}{*}{ Resin Beds: } & & Cation Resin & Resin Rat10 & Flow, $\mathrm{gpm} / \mathrm{ft} \mathrm{t}^{2}$ \\
\hline & $\begin{array}{l}\text { Filter/ } \\
\text { Demineralizer }\end{array}$ & $\mathrm{NH}_{4}^{+}$. & $1 / 1 \mathrm{w} / \mathrm{o}$ & 4 \\
\hline & $\begin{array}{l}\text { Filter/ } \\
\text { Demineralizer }\end{array}$ & $\mathrm{NH}_{4}^{+}$ & $2 / 1 \mathrm{w} / \mathrm{o}$ & 4 \\
\hline & Deep Bed 1 & $\mathrm{NH}_{4}^{+}$ & $5 / 1 \mathrm{v} / \mathrm{o}$ & 50 \\
\hline
\end{tabular}

Test 2

Repeat test except with $20 \mathrm{ppm}$ ammonia added to fced ( $\mathrm{pH} \sim 10)$.

Test 3

After test 3 is complete additional tests may be scheduled depending on the time and resources available and the insights gained in the first three runs. 
NEDC-23856-3

3.7 TASK B-6. RADWASTE SYSTEM IMPACT (E. L. Burley)

Objective. Predict the radwaste inputs (amount and composition) accompanying the potential changes in water chemistry. Evaluate the effect of these loads on equipment capacity, construction materials, processing sequence, etc. Determine the cost of the resulting, modified radwaste system.

\subsubsection{System Changes}

The impact of an ammonia additive on the radwaste system is twofold: more and stronger chemical regenerants must be used to achieve the high degree of regeneration required, and the lowered ionic capacity of the resins requires more frequent regenerations.

The increased chemical consumption and resultant increased radwaste volume are illustrated in Table 3-30. The dramatic decrease in bed life at the high $\mathrm{pH}$ operating condition is also shown.

Even at the current $\left[\mathrm{H}^{+}-\mathrm{OH}^{-}\right]$cycle regeneration frequency, chemical waste input to the radwaste system and final stored waste volumes therefrom are increased by factors of 4.6 and 5.2, respectively. If the decreased bed life is also considered, this increase becomes about 200-fold: clearly intolerable, both from the standpoint of system processing capacity and final waste volume.

\subsubsection{Alternatives}

If the amounts of sodium and chloride in the condensate were limited to 2.4 and $3.7 \mathrm{ppb}$, respectively (at the price of jeopardized plant availability) these elements would very rapidly establish an equilibrium with the ammonia bascd condensate treatment system resins and pass through them with no concentration change. Then, in a $7 \%$ clean-up system plant all sodium and chloride removal would take place in the lower $\mathrm{pH}$ clean-up system where resin capacities are much higher. 
NEDC-23856-3

Table 3-30

RESIN REGENERATION WASTE

\begin{tabular}{|c|c|c|c|}
\hline & $\begin{array}{l}\text { Standard } \\
\text { BWR } \\
\end{array}$ & $\begin{aligned} \quad \mathrm{NH}_{3} \\
\text { F1ow Sheet }\end{aligned}$ & $\begin{array}{r}\mathrm{NH}_{3} \text { Flow Sheet } \\
+5 / 1 \text { Resin Ratio } \\
\end{array}$ \\
\hline Resin Ratio (By Volume) & $2 / 1$ & $2 / 1$ & $5 / 1$ \\
\hline \multicolumn{4}{|c|}{ Chemical Requirements, $1 \mathrm{~b} / \mathrm{ft}^{3}$ Resin } \\
\hline $\mathrm{H}_{2} \mathrm{SO}_{4}$ (cation resin) & 8 & 20 & 20 \\
\hline $\mathrm{NaOH}$ (anion resin) & 6 & 15 & 15 \\
\hline $\mathrm{NH}_{3}$ (all resins) & $\cdots$ & 8 & 8 \\
\hline \multicolumn{4}{|c|}{$\begin{array}{l}\text { Pounds of Neuiralized Chemicals/ } \\
\text { Regeneration }\end{array}$} \\
\hline $\mathrm{Na}_{2} \mathrm{SO}_{4}$ & $140 n$ & 1600 & 800 \\
\hline$\left(\mathrm{NH}_{4}\right)_{2} \mathrm{SO}_{4}$ & -- & 5600 & 5600 \\
\hline \multicolumn{4}{|c|}{$\begin{array}{l}\text { Volume of Chemical Waste per } \\
\text { Rcgeneration (gal) }\end{array}$} \\
\hline $\mathrm{Na}_{2} \mathrm{SO}_{4}$ Soln & 5300 & 6300 & 3000 \\
\hline$\left(\mathrm{NH}_{4}\right)_{2} \mathrm{SO}_{4}$ Soln & -- & 21000 & 25000 \\
\hline \multicolumn{4}{|l|}{ Operating Resin Capacity } \\
\hline $\begin{array}{l}\text { Cation Reoin, meq/inl } \\
\text { Anion Resin, meq/ml }\end{array}$ & $\begin{array}{l}0.55 \\
0.28\end{array}$ & $\begin{array}{l}0.0023 \\
0.025\end{array}$ & $\begin{array}{l}0.0023 \\
0.025\end{array}$ \\
\hline \multicolumn{4}{|c|}{$\begin{array}{l}\text { Single Bed Life With } 12 . \mathrm{gpm} \\
\text { Cooling Water Leak, } \mathrm{hr}\end{array}$} \\
\hline $\begin{array}{l}\text { Cation Resin } \\
\text { Anion Resin }\end{array}$ & $\begin{array}{r}2400 \\
600\end{array}$ & $\begin{array}{l}10 \\
54\end{array}$ & $\begin{array}{l}13 \\
27\end{array}$ \\
\hline
\end{tabular}


Under these conditions clean-up bed life would be extended so that one clean-up bed regeneration was required each $35 \mathrm{hr}$ opposed to one condensate bed regeneration every $2 \mathrm{hr}$. However, in a $1 \%$ (current standard) clean-up system, reactor water chloride concentration and conductivity would exceed established reactor water quality limits. Also, the radwaste system activity levels would be significantly and perhaps intolerably increased by having to handle clean-up resins and/or spent regenerants rather than those from the condensate system which is isolated from reactor water activities. In any case operation at "zero" condenser leakage represents a minimum radwaste volume increase of about six times that for the current non-additive flow sheet, increased operating problems notwithstanding. It is not considered a feasible alternative. 
3.8 TASK B-7. INJECTION AND CONTROL EQUIPMENT (J. D. Seymour, N. A. Fedrick)

Objective. Identify the proper system locations at which to inject the additives and select the proper equipment for this purpose. Select the position at which to obtain a representative sample and the type of control instrumentations to use to monitor and control additive addition rate.

\subsubsection{Hydrogen Injection System Selection}

Studies performed at the Humboldt Bay reactor site and the General. E1ectric Company showed ${ }^{19}$ that hydrogen, when injected directly into reactor feedwater does not readily dissolve because huhh1e soalescence causes stratificatiun of the gas. To preclude gas-phase stratification, it was derided to injcct the hydrogen into a gas-liquid contacting device in a side-stream which would then be mixed with the main feedwater flow.

\subsubsection{Design Basis}

Design of the hydrogen injection system was based on the criteria listed in Table 3-31.

Table 3-31

RECUMMENDED DESIGN CRITERIA

Location of injection point

Ilydioym gao flowrate

Space limitation

Cumlol rcquirements

Degree of Automation
Suction of reactor feedwater pumps

System should be capable of injecting 2 to $30.1 \mathrm{~h} / \mathrm{hr}$

Small as practical

system should be designed to inject hydrogen into the feedwater in direct proportion to feedwater flow

System should he alitnmated in such a manner as to maintain a constant injection flow in proportion to feedwater flow. The system should be capable of operating unattended with only weekly maintenance. 
These criteria were met with the exception of the location of the injection point. The feedwater pumps (Dresden 2) are not capable of accommodating the additional flow as a result of recirculation through the side stream. A point immediately downstream of the pumps was chosen because it was near the recommended location, it has a higher pressure which provided a more favorable gas-to-liquid driving force, and it eliminated the potential problem of bubbles cavitating the pumps.

A $10 \%$ (of feedwater) or one million $\mathrm{lb} / \mathrm{hr}$ flowrate was chosen for the side stream because with the maximum amount of hydrogen being dissolved ( $30 \mathrm{lb} / \mathrm{hr}$ ) in this volume of water, the concentration of the gas ( $230 \mathrm{ppm}$ ) is sufficiently far removed from the equilibrium concentration ( $185 \mathrm{ppm}$ ) as to maintain a satisfactory gas-to-liquid driving force.

The side stream inlet temperature was taken as $300^{\circ} \mathrm{F}$. The side stream inlet pressure was taken as 1250 psig although it could increase to 1650 psig (pump shutoff discharge head) at low feedwater flow rates. Pressure integrity design was based on the maximum possible system pressure. Gas absorber design, however, was based on minimum system pressure, and maximum hydrogen gas flow.

\subsubsection{Types of Gas-Liquid Contractors Studied}

Four gas-liquid contacting devices were considered: a packed column operated in the conventional manner, i.e., countercurrent flow with a continuous gas phase; a packed column operated in cocurrent flow with a discontinuous gas phase; a bubble column; and a bubble column containing a motiunless (static) mixing element to promote gas bubble dispersion and gas-liquid contact.

These contacting devices were compared qualitatively on the basis of interfacial area, mass transfer coefficient, operating range, size, and cost. This comparison is summarized in Table 3-32.

Data on interfacial area were obtained from the study performed by Wang and Fan $^{20}$, who compared the interfacial area for gas-liquid contacting in a 
Table 3-32

A COMPARISON OF FOUR GAS-LIQUID CONTACTING DEVICES

$\begin{array}{lcccc}\begin{array}{l}\text { Basis for } \\ \begin{array}{c}\text { Comparison } \\ \text { (Worst }=1 \\ \text { Best }=4 \text { ) }\end{array}\end{array} & \begin{array}{c}\text { Countercurrent } \\ \text { Packed } \\ \text { Tower }\end{array} & \begin{array}{c}\text { Cocurrent } \\ \text { Packed } \\ \text { Tower }\end{array} & \begin{array}{c}\text { Bubble } \\ \text { Column }\end{array} & \begin{array}{c}\text { Bubble Column } \\ \text { with } \\ \text { Static } \\ \text { Mixers }\end{array} \\ \begin{array}{l}\text { Interfacial } \\ \text { Area }\end{array} & 1 & 2-3 & 2-3 & 4 \\ \begin{array}{l}\text { Mass Transfer } \\ \text { Coefficient }\end{array} & 1 & 2-3 & 2-3 & 4 \\ \begin{array}{l}\text { Operating Range } \\ \text { Size }\end{array} & \text { Narrow } & \text { Variable } & \text { Variable } & \text { Variable } \\ \text { Cost } & 1 & 1 & 3 & 4\end{array}$

tower with conventional packing, e.g., Raschig rings, in a bubble column, and in a bubble column with static mixing elements. They found the interfacial area for the Koch static mixers to be highest. The advantage of the mixing element over the conventional tower packing is that the former occupies a smaller percentage of vessel volume for a given contact area.

Contacting devices for insoluble gases are often compared on the basis of their $\mathrm{K}_{\mathrm{L}} \mathrm{a}$, the product of the liquid-phase mass transfer coefficient and the gas-1iquid interfacial area. The data of Houghton, et al. ${ }^{21}$ indicate that the bubble column is superior to the packed column for the absorption of carbon dioxide at low gas flows. Their results are shown in Figurc 3-26. Wang aud Fan compared the $K_{L}$ a of bubble columns with the $K_{L}$ a of the Koch static mixer and found the Koch device to be superior at low gas flow rates (Figures 3-27).

In terms of operating ranges for the various contactors, it was postulated that the countercurrent packed tower would probably have a limited operating range due to the low gas absorption at high water flows, necessitating a liylrugen armosphere (continuous gas phase) in the vessel with recycle or make-up gas streams. At low water flows, on the other hand, the hydrogen 
NEDC-23856-3

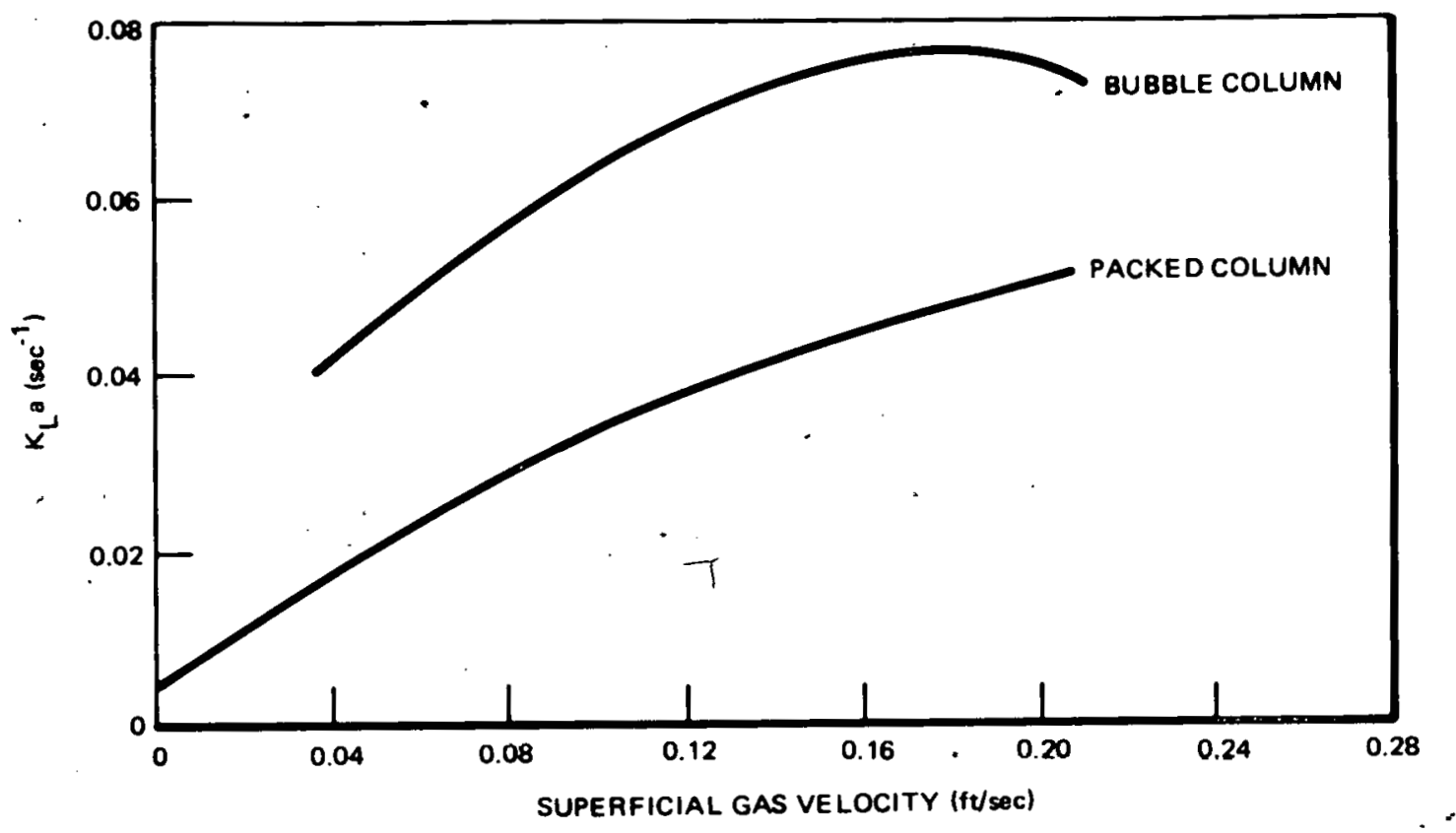

Figure 3-26. Column Efficiency versus Superficial Gas Velocity

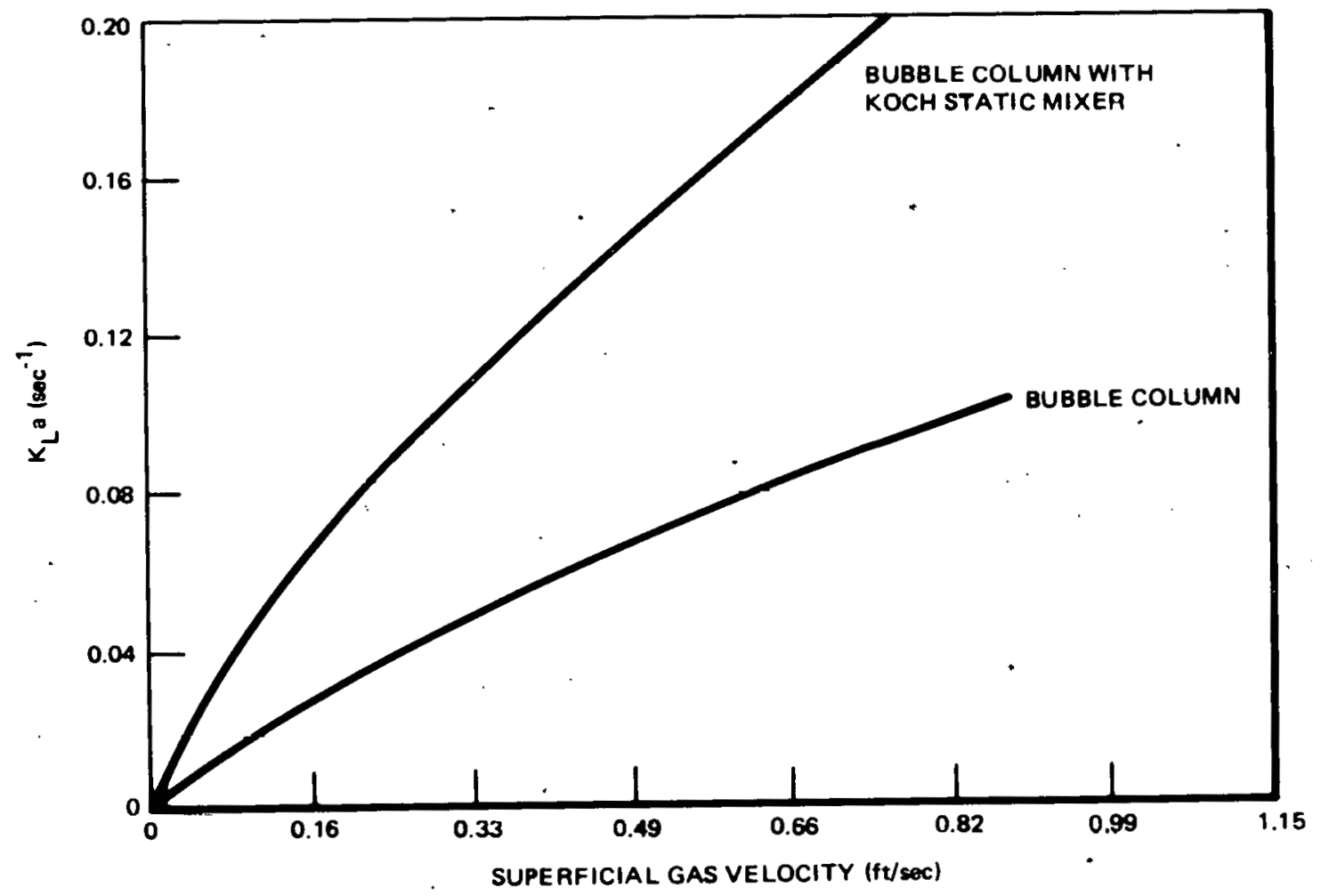

Figure 3-27. Comparison of Liquid-Phase Mass Transfer Coefficients 
atmosphere would result in greater-than-desired hydrogen absorption and difficult process control -- a definite negative aspect of this device. Operating ranges for the other contactors would be variable and a specific comparison was not at tempted.

With respect to size, a packed tower (either countercurrent or cocurrent) could pose a definite location and installation problem. Based on a maximum allowable mass flow capacity of the tower of 20,000 to $30,0001 \mathrm{~b} / \mathrm{hr}-\mathrm{ft}^{2}$, the vessel diameter would be on the order of 7 to $9 \mathrm{ft}$, with a projected height of approximately 10 to $15 \mathrm{ft}$. The bubble column (with or without statir mixers), however, would be simply a length of pipe with a diameter nf ahnut 12 in. In addition, thio device is most flexible in terms of physical arrangement: it may be installed vertically or horizontally; it may be formed into a helix if installation space is limited; elements may be added or deleted as system requirements change.

Because of the large size and the necessity that the absorber be a pressure. vessel, the cost of a packed tower was estimated to be approximately 5 to 10 times greater than for a bubble column. The difference in cost between the two bubble columns could be the cost in procuring and installing the mixing elements -- a relatively low cost differential.

Based on the above information the bubble column with the static mixing elements was chosen as the most effective gas-liquid contactor.

\subsubsection{Design}

'Ihe design is dependent primarily on the mass transfer coefficient. The mechanism tor mass transfer, in general, is complicated and not fully understood. When the mechanics of bubble action and turbulence are included, it becumes exceedingly complex. For this reason a purely theoretical prediction of a mass transfer coefficient is not possible. 20 It is necessary, therefore, to employ correlations based on experimental data. 
Researchers at Koch, Inc. have derived a design equation empirically. It is based on an oxygen-water system at ambient temperature and atmospheric pressure. In applying this equation to the injection of hydrogen gas several assumptions were made:

a. Hydrogen gas is a relatively insoluble substance; therefore, the resistance to mass transfer is wholly in the liquid phase.

This was found to be generally true. However, there may be an added effect of gas-phase resistance if the ratio of liquid molal flow rate to gas molal flow rate is large, as is the case here. There was no information, however, for determining the extent of this effect.

b. The diffusivity of hydrogen gas in water is dependent on the liquid viscosity/temperature ratio and not directly on pressure.

Although very little research has been done in this area, it seems that increased pressure decreases diffusivity by reducing the intramolecular spacing. 22 It is indicated that the effect of pressure on viscosity may be proportional to the effect of pressure on diffusivity. For water, though, pressure has little or no measurable effect on viscosity and probably no effect on diffusivity. 22 1

c. The mechanism of mass transfer in a static mixer follows the two-film theory as opposed to the pentration thcory.

For this application the important difference in the two theories is the effect of diffusivity on the mass transfer coefficient. The two-film theory supposes that $\mathrm{K}_{L} \mathrm{a}$ is directly proportional to the diffusivity while the penetration theory assumes $\mathrm{K}_{\mathrm{L}}$ a to be proportlund to the square root of the diffusivity. The two-film theory is supported by Koch researchers and by Wang and Fan for the Koch 
static mixers. The penetration theory has been accepted by many investigators for devices such as the agitated bubble column and packed tower.

d. $K_{L}$ a is independent of liquid flow rate.

Although this is not true, this assumption leads to a very conservative design in this case.

e. Gas absorption is a logarithmic function.

This is a result of the kosh reccarch. 23

t. $\bar{K}_{L}$ a values for the Koch type "LY". mixer are essentially the same as those for the type "AY" mixer.

The difference between the two types of mixers is the distance between the layers. The LY mixer has 1-in. layer separation, while the AY type has 0.5-in. layer separation.

\subsubsection{Calculations}

The cmpirical design equation derived at Koch research facilities is: ${ }^{23}$

$$
L=\frac{Q}{K_{L} d A \overline{\bar{x}}}
$$

wherc

$$
\begin{aligned}
& \mathrm{L}=\text { length of mixer, } \mathrm{ft} \\
& \mathrm{Q}=\text { Gas absorbed in a section of pipe, molles } / \mathrm{min} \\
& \mathrm{A}=\text { Cross sectional area of pipe, } \mathrm{ft}^{2} \\
& \overrightarrow{\mathrm{x}}=\text { Log mean driving force defined as }
\end{aligned}
$$




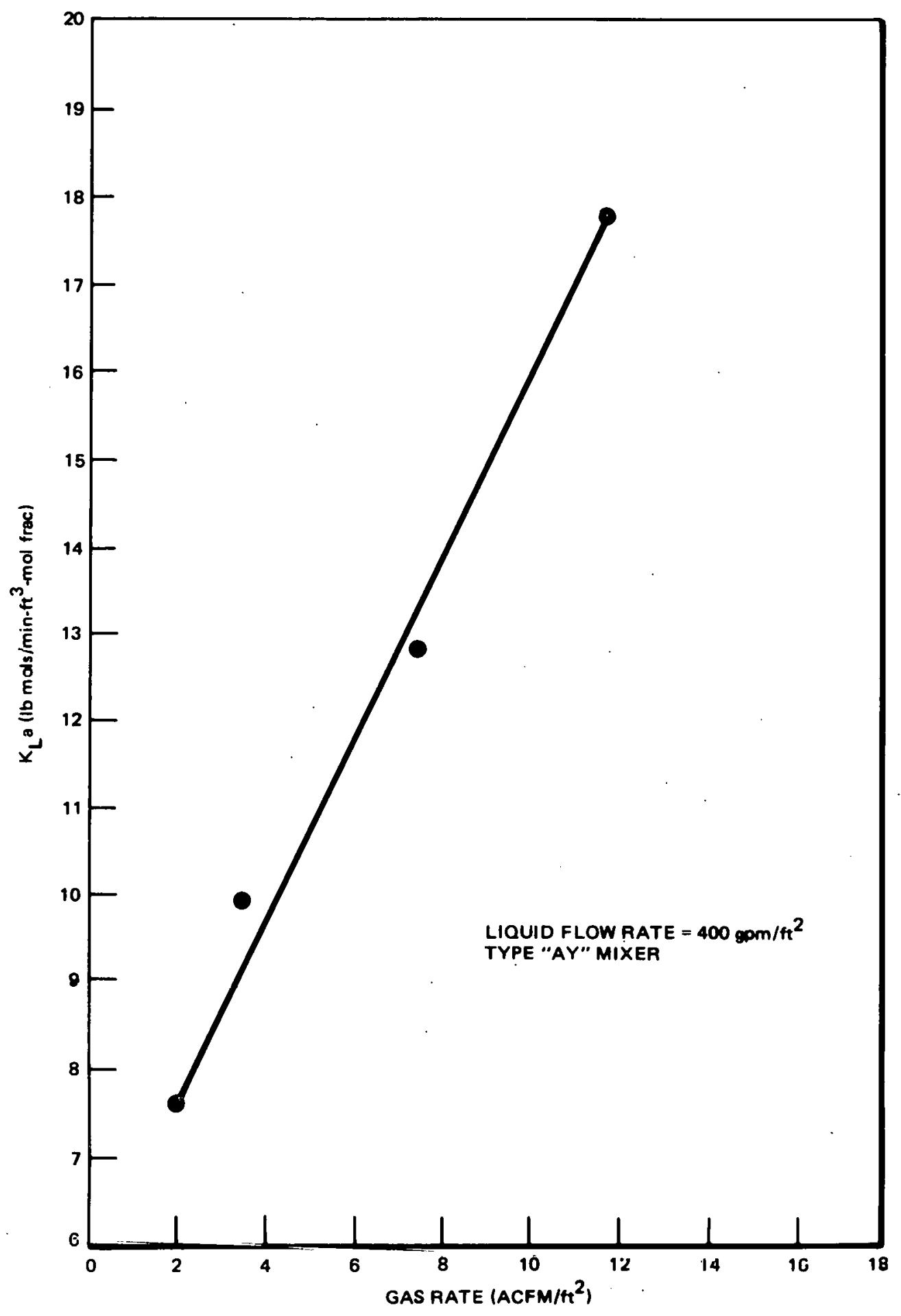

Figure 3-28. Correlation for $\mathrm{K}_{L}$ a Based on $\mathrm{O}_{2}-\mathrm{H}_{2} \mathrm{O}$ System 


$$
\frac{\left(x^{*}-x_{i}\right)-\left(x^{*}-x_{f}\right)}{\ln \left(\frac{\left(x^{*}-x_{i}\right)}{\left(x^{*}-x_{f}\right)}\right)}
$$

$$
\begin{aligned}
x_{i}, x_{f}= & \text { Mole fraction of gas dissolved in liquid at some initial and } \\
& \text { final point, respectively, dimensionless } \\
x^{*}= & \text { Mole fraction of gas dissolved in liquid at equilibrium. This } \\
& \text { may be computed from Henry's Law.* }
\end{aligned}
$$

The value ful $K_{L}$ a 1 s obtained from a correlation pruvided by kock (Figure 3-28). The $K_{L}$ a value from the graph must be corrected for the hydrogen-water systom ${ }^{23}$

$$
\mathrm{K}_{L^{a}}{ }^{a}\left(\mathrm{H}_{2}-\mathrm{H}_{2} \mathrm{O}\right)=\mathrm{K}_{L^{\mathrm{a}}}{ }^{\mathrm{a}}\left(\mathrm{O}_{2}=\mathrm{H}_{2} \mathrm{O}\right) \times\left(\frac{\mathrm{D}}{\frac{\left(\mathrm{H}_{2}-\mathrm{H}_{2} \mathrm{O}\right)}{\left(\mathrm{O}_{2}-\mathrm{H}_{2} \mathrm{O}\right)}}\right)
$$

where

$$
\mathrm{D}=\text { diffusivity, } \mathrm{cm} / \mathrm{sec}
$$

The range of $K_{L}$ a values that $r a n$ be obtained $\Gamma_{\text {L }}$ in the graph is small because of the low gas flow rate. Koch suggested that a length for the mixing elements be determined by using the $K_{L}$ a for which there was a data point; then a logarithmic curve could be generated from the equation:

$$
L=C \ln (1-A b s)
$$

\footnotetext{
*Henry's Law: ${ }^{24} \quad \mathrm{p}-\mathrm{Hx} *$

where $\mathrm{p}=$ partial pressure of the gas, atm $\mathrm{H}=$ Henry's Law constant for the gas, atm/mol frac.
} 
where

$$
\begin{aligned}
\mathrm{C} & =\text { constant } \\
\mathrm{Abs} & =\text { fraction of gas absorbed }
\end{aligned}
$$

Using this method a hydrogen gas absorption curve was generated (Figure 3-29). Fourteen feet of mixing section was required to dissolve $99.95 \%$ of the hydrogen at an initial flow rate of $30 \mathrm{lb} / \mathrm{hr}$. Sample calculations are given in Appendix B:

\section{8 .3 Results}

The design of the gas-1iquid mixing section consists of a 12-in.-diam pipe, $40 \mathrm{ft}$ long, containing 14, 1-ft-long Koch static mixing elements. Empty pipe sections between the mixing elements extend the gas-liquid contact time without appreciably adding to the overall pressure drop. Hydrogen gas will be injected upstream of the first mixing element through a sparger or fritted disc. The mixing section is depicted in Figure 3-30.

The mixing section installation and arrangement is shown in the P\&ID, Figure 3-31.

A screen downstream of the mixing section (not shown) will be included to prevent carryover of debris in the event of disintegration of any of the mixing elements. Hydrogen gas flow is controlled in direct proportion to the side stream flow rate which is, itself, controlled in direct proportion to the flow rate of the main feedwater stream.

\subsubsection{Conclusions and Recommendations}

The present design of the hydrogen injection system should be adequate to dissolve the required amounts of hydrogen gas at the prescribed conditions. 


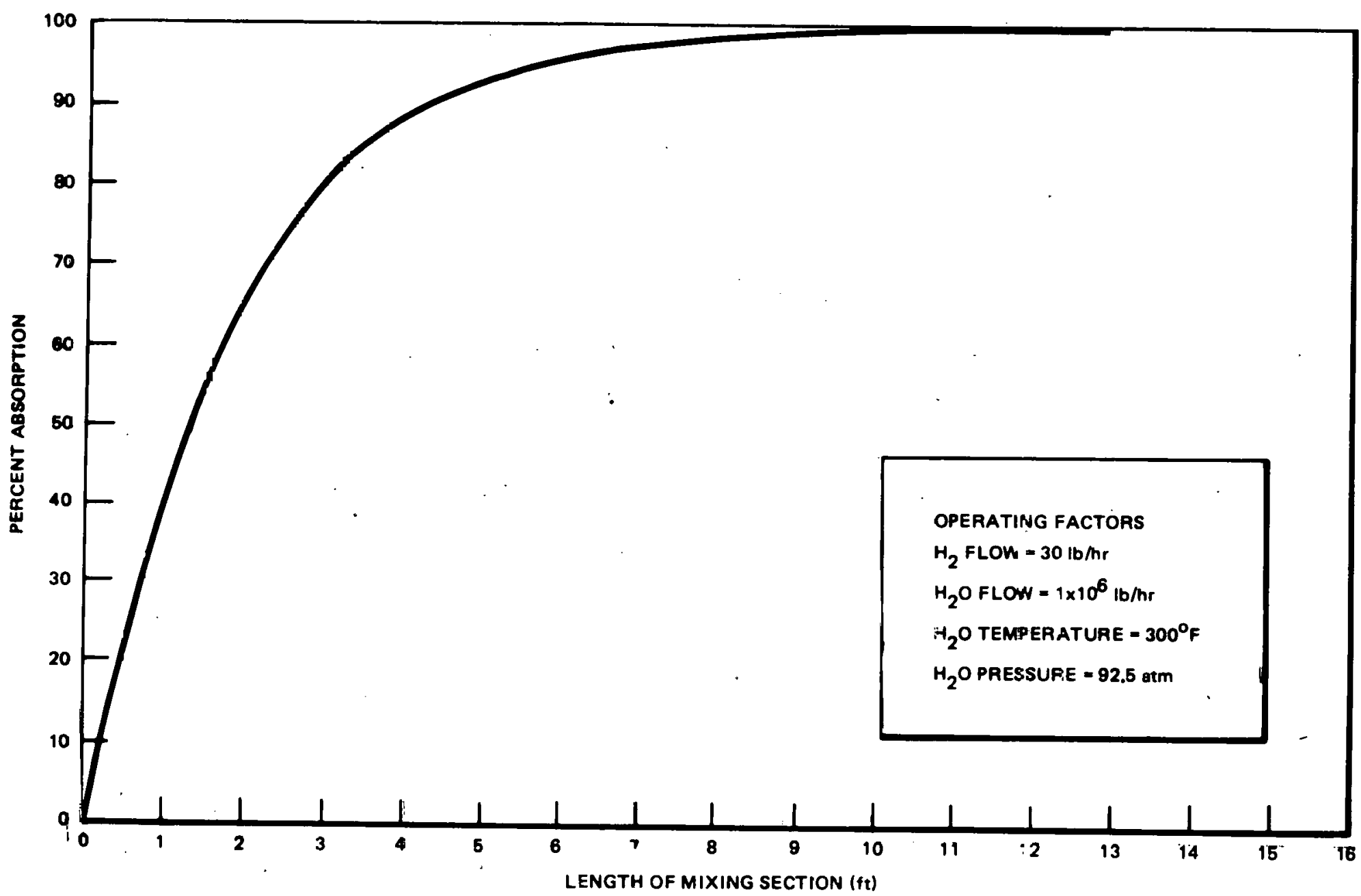




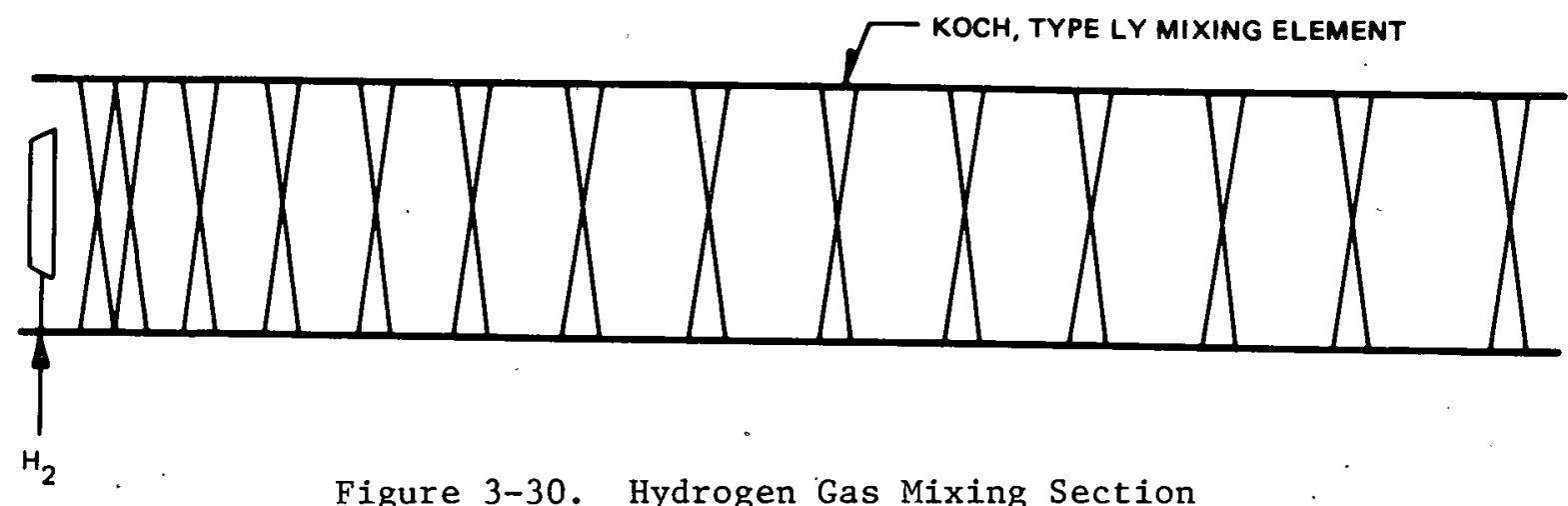

Although a very conservative approach has been taken in designing this system, there is still some uncertainty inherent in the design. The assumptions made in this case, (resistance to mass transfer is liquid-phase controlled, a $\mathrm{K}_{\mathrm{L}} \mathrm{a}^{\mathrm{a}}$ is proportional to the diffusivity (Two-Film Theory), etc.) if not strictly correct or applicable, could yield a less conservative design, resulting in a mixing section longer than presently specified. It should be noted, though, that the total length of mixing section may not necessarily increase as the mixing elements may be installed closer to each other than in the present design.

To obtain a precise design for the mixing section length laboratory testing is called for. It is recommended that laboratory testing he undertaken on hydrogen dissolution at high temperature and pressure to obtain a more accurate correlation for the mass transfer coefficient. In addition, horizontal and vertical performance testing should be carried out to determine if any advantages exist in operating the mixing section in one position rather than the other.

\subsubsection{Cost Analysis}

The estimated cost for the procurement and installation of such a hydrogen injection system is itemized in Table 3-33. The system was estimated on the basis of meeting ASME Boiler and Pressure Vessel Code, Section III, Subsection NB requilements when added to the feedwater line at an existing nuclear power plant. Equipment and hardware to be procured are given in Appendix A. 


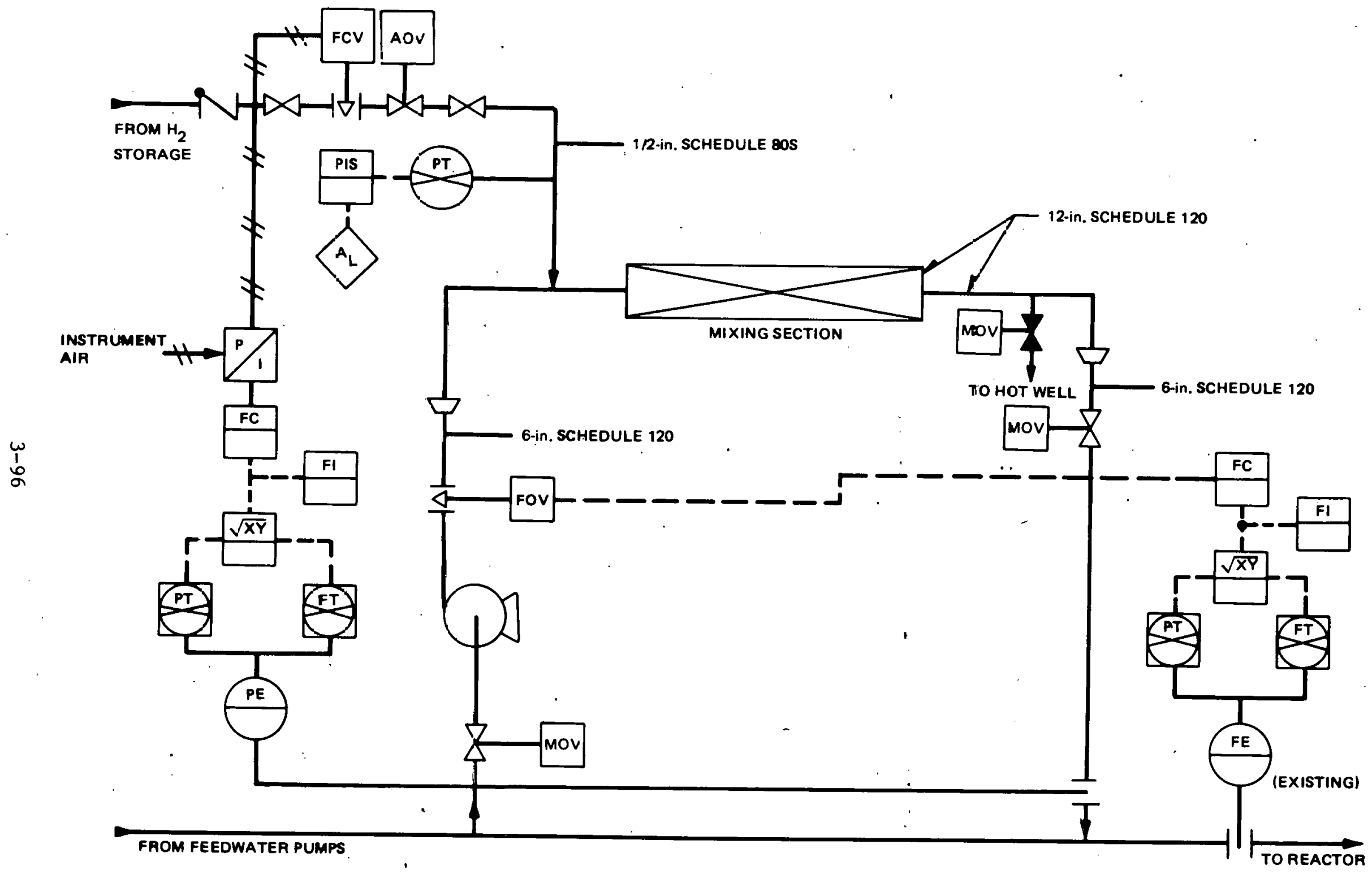

Figure 3-31. P\&ID for Hydrogen Injection Systen 
NEDC-23856-3

Table 3-33

COST ESTIMATE FOR HYDROGEN INJECTION SYSTEM

1978 Dollars

- Purchased Parts

257,000

Subcontracted Items (Including Installation)

Other/Raw Material

166,500

3,500

Direct Labor + Overhead

15,000

TOTAL COST

$\$ 442,000$ 
NEDC-23856-3

3.9 TASK B-8. OPERATIONAL AND OTHER RELATED CONSIDERATIONS (R. J. Stevens, T. L. Wong, E. G. Leo, B. S. Shiralkar, J. D. Duncan, C. C. Lin, J. S. Wiley)

Objective. Consider and evaluate the effects of each additive on "normal" plant operation, e.g. manpower requirements, special safety or toxicity precautions, employee acceptance, licensing considerations and variations in radioactivity transport and deposition patterns.

\subsubsection{Additive Surveillance Requirements}

System surveillance must be maintained to monitor for process control, and to monitor additive handling areas for control of health and safety hazards.

The first category is covered under Task B7. For personnel health and safety however monitors should be user in encloocd areas sull ds the additive storage, distribution, and injection system areas.

The levels of concern for each proposed additive are shown in Table 3-34 as Threshold Limit Values (TLV), which are the maximum permissible levels in air related to toxicity/personnel health hazard, and Lower Explosive Limits(LEL) in air. These levels are in volumetric parts per million (vppm) or percent by volume in air.

Table 3-34

ADDITIVE. CONCENTRATION LIMITS IN AIR

\begin{tabular}{|c|c|c|}
\hline Additive & TLV & $\begin{array}{l}\text { LEL } \\
(\%) \\
\end{array}$ \\
\hline Ammonia $\left(\mathrm{NH}_{3}\right)$ & $50 \mathrm{ppm}$ & 15 \\
\hline Hydrazine $\left(\mathrm{N}_{2} \mathrm{H}_{4}\right)$ & $1 \mathrm{ppm}$ & 4.67 \\
\hline Hydrogen $\left(\mathrm{H}_{2}\right)$ & $7 \% *$ & 4.1 \\
\hline
\end{tabular}


The normal practice for these types of monitoring systems is to set the alarm levels at approximately one half $(1 / 2)$ of the above values to provide a sufficient margin for early remedial action. As a minimum the monitoring equipment should undergo daily operational checks.

Wherever possible, redundant monitoring equipment based on more than one measurement technique should be used.

\subsubsection{Operational Guidelines}

The start-up and normal mode operational considerations are, in part, a function of the injection and control system selected. The operational guidelines specific to the injection and control system are not covered in this task. However, the general considerations which apply in the three additive cases are as follows:

Addition systems shall be thoroughly purged with helium prior to the introduction of the additive, prinr to any system repairs, and prior to restart of the system.

The reactor sub-system where the additive is introduced (i.e., containing the injection point), must be in operation prior to start-up of the addition system. The injection rate should be proportional to the flow rate of the reactor sub-system at the injection point.

Any plant or sub-system shutdown which isolates or stops flow at the injection location, should also automatically isolate and shut down the injection system.

Enclosed additive storage and usage areas should be monitored for leakage. Detection of the additive above one half the lower explosive limit (LEL) in air should automatically isolate the additive supply. The distribution/ injection system should be immediately purged with helium, and the leak source should be repaired prior to restart of the additive system. 
During such emergencies, personnel entering the area should use gas masks or self contained breathing apparatus until the area can be ventilated and brought below one-half the threshold limit value (TLV) for ammonia and hydrazine.

When ammonia or hydrazine levels above one-half the TLV but below one-half the LEL are detected, personnel with gas masks and other protective clothing may investigate for leakage without system shutdown. Shutdown and thorough purging of the system are required prior to initiation of repair work, however.

\subsubsection{Special Training}

Ammonia and hydrazine are highly caustic substances. Therefore, personnel working in the additive system area should be alerted to their hazards and they should also be trained in the proper use of protective clothing and breathing apparatus (gas masks, self contained air supplies, etc.).

Hydrogen's primary hazard is its highly flammable nature. Personnel working with hydrogen or in areas where hydrogen is presene should be trained in proper procedures for handling of hydrogen and working with equipment, in areas where hydrogen is stored.

Additionally, the additives must be dealt with carefully during a fire situation. An error in fire fighting techniques may result in greatei liazards than the original fire. Therefore, personnel should be instructed In chc proper techniques for fire fighting associated with each additive.

\subsubsection{Special Equipment}

Due to the caustic nature of ammonia and hydrazine, the following items should be available in the additive system area: Emergency eyewash and shower stations, protective clothing such as rubber gloves and aprons, goggles, and emergency breathing apparatus. 
NEDC-23856-3

A liquid hydrogen supply system would require temperature and/or pressure monitoring of the storage vessels to detect potential over-pressurization of the vessel and attached piping.

Monitors are also required in additive usage areas. These monitors must have range capabilities to cover the TLV and LEL for the additive in use. (This may be accomplished by use of two different monitors to cover the required range.)

A brief review of some of the available types of monitors for each of the additives is given below. It is, however, recommended that the various monitoring techniques for the chosen additive be tested for operation at the representative conditions prior to final selection of a specific monitor.

\subsubsection{Ammonia Detection Methods}

\subsubsection{Solid State Electrolyte Sensor}

This sensor is a solid state semiconductor material sensitive to ammonia. In the presence of ammonia the conductivity of the sensor increases proportionately to the amount of ammonia. The sensor is capable of measurements at or below one-half the threshold limit value of ammonia, but at these concentration is subject to interference or masking from other trace substances. Systems of this type are offered by International Sensor Technology Co. of Santa Ana, California and the FnMet Corp. of Ann Arbor, Michigan.

\subsubsection{Photoionization}

An ultraviolet light is used to ionize a particular substance by bombarding the sample stream with photons having an energy level at or above the ionization potential of the substance, but below that required for the major components in air. This method is subject to interference from other trace elements when the species of interest is at a low concentration. This system is manufactured by HNU Systems, Inc., of Newton Upper Falls, Massachusetts. 
NEDC-23856-3

\subsubsection{Infrared Analyzers}

The operation of this system is based on the wavelength absorption characteristics of the substance of interest. An infrared "beam" is passed through the sample gas to a receiver. The reduction of energy at a specific wave length is a function of the concentration of the substance of interest. This system is less susceptible to interference. An infrared system capable of monitoring ammonia is offered by the Wilkes Division of Foxboro Company, of Burlington, Massachusetts.

\subsubsection{Specific Electrode}

This sensing method requires that a batch Eamplc of gas be bubbled through a liquid where the ammonia will go into solution and be detected by the "spectfic" electrode. The problems associated with this system are the designs of the calibration and batch cycling systems. The specific electrode is offered by Lazaar Research Labs of Los Angeles.

\subsubsection{Hydrazine Detection Methods.}

With some modification the methods discussed above for ammonia may be used for monitoring hydrazine. The specific electrode system will. not measure hydrazine directly but may be used if an iodate solution is used as the absorbent. The iodate is converted to ionic iodide by the hydrazine. Therefore, the iodine electrode response will then be proportional to the hydrazine content of the air.

\subsubsection{Hydrogen Detection}

\subsubsection{Solid Statc Electrode jensor}

The sensor described above may also be used for hydrogen detection. At the monitoring levels for hydrogen ( $2 \%$ ) there is less interference due to other impurities. 


\subsubsection{Therma1 Conductivity}

Variations in the thermal conductivity of a gas mixture may be used to indicate changes in the make-up of the gas. If the base gas mixture is known and remains constant, the level of concentration of an additive such as hydrogen may be measured. The thermal conductivity of a gas is measured using a heated coil in the sample gas stream. The temperature of the coil will stabilize based on the thermal conductivity of the gas. The coil resistance then is monitored as a temperature indication. This system is most effective when used in a two-component stream. Monitoring of ambient air is difficult since the components are not constant in concentrations. Also, this type of monitor is highly sensitive to moisture in the air. Thermal conductivity type sensors are offered by Teledyne Analytical Instruments of San Gabriel, Califórnia.

\subsubsection{Catalytic Bead Sensor}

This type of sensor is often used for combustible materials such as hydrogen; a catalyst bead is used to "burn" the hydrogen, thus heating the bead element. Once again the resistance of the element is measured as an indication of the temperature and therefore the hydrogen concentration. One of the primary problems with catalytic type sensors is the potential of poisoning the catalyst, which reduces the efficiency of hydrogen conversion. The Catalytic Bead Sensor system is offered by vendors such as Teledyne Analytical Instruments of San Gabriel, California, Dictaphone of Mountain View, California, and others.

\subsubsection{Color Indicator Tubes}

A sensiug method which may be considered for manual backup is based on indicator tubes such as those offered by Drager (National Mine Service Company). These tubes when used with a hand suction pump give an indication of the concentrations of a particular trace component by a color change in the tube. These tubes can be used to measure down to the levels of concern for all three of the additives. 


\subsubsection{Additional Procedure Requirements}

The additive system will require specific start-up, shut-down, isolation and purging procedures. The reactor subsystem containing the injection system will require procedural changes for startup and shutdown.

Special fire fighting procedures for each additive have been discussed. 18 Unique elements of these procedures should be addressed in the site emergency/ fire fighting procedures.

\subsubsection{Emergency Core Cooling System}

The AWC additives and their resultant modification of the $\mathrm{ll}_{2}$ and $0_{2}$ leve.1s in the reactor vessel will have no impact on the ECCS for there is no change in the suppression pool concentrations and this pool is the source of ECCS watèr.

\subsubsection{Post-LOCA Hydrogen Concentrations}

The potential for an increase of post-LOCA hydrogen concentration due to an AWC system was evaluated. The increased hydrogen concentration in the core coolant causes an increase of approximately $0.1 \%$ (by Volume) $\mathrm{H}_{2}$ gas in the drywcll for Mark I and III plants. This slight increase however doec not result in a post-LOCA hydrogen concentration exceeding $4 \%$ (by volume), the lower explosive limit for hydrogen in air. Figure 3-32 shows the buildup of hydrogen in the drywell as a function of time, for normal water.

\subsubsection{Crud and Radioactivity Transport and Build-up}

The buildup of crud on fuel heat transfer surfaces after and during operation with hydrogen added to the BWR feedwater is an important consideration. A literature search failed to reveal any pertinent information. A trip to the AECL laboratories at Chalk River was made to review data from a boiling 
loop that had operated with hydrogen addition. Experimental conditions are given in Table 3-35 and the results in Table 3-36. The crud levels of 10 to $35 \mathrm{ppb}$ in the NRX reactor loop are typical of BWR operations although levels of $100 \mathrm{ppb}$ are common at Brunswick 2 .

Fuel crudding rates have been extensively studied for BWR fuel and Figure 3-33 compares the axial shape of the expected BWR values with the distribution shown in Table 3-36. Both cases have been arbitrarily normalized to unity at the bundle inlet. Deposit weights cannot be compared directly because the AECL test (684) ran for only about a month compared to BWR fuel residence times of years. Only relative comparisons of the observed deposits can be made. The 684 test revealed what appears to be a marked Reynolds number dependency and the deposits were distributed relatively more uniformly along the fuel bundle than the General Electric BWR. Undoubtedly the Reynolds number changes contributed to the alternating decrease and then increase in deposition rates within the bundle, probably due to changes in velocity.

A considerable amount of time was taken during the AECL meeting discussing crud morphology. AECL had run the NRX loop with neutral chemistry and with hydrogen added and in both cases reported the fuel crud to be $\mathrm{Fe}_{2} \mathrm{O}_{3}$. This is also the dominant corrosion product species found on the BWR fuel. The $\mathrm{Fe}_{2} \mathrm{O}_{3}$. was stable even when the boiling test fuel element was returned to the regular CANDU environment. They were questioned as to their expectation of crud bursts upon start of hydrogen injection into an old plant and no such crud bursts were anticipated, because of the observed stability of the $\mathrm{Fe}_{2} \mathrm{O}_{3}$ and $\mathrm{Fe}_{3} \mathrm{O}_{4}$ structures. 


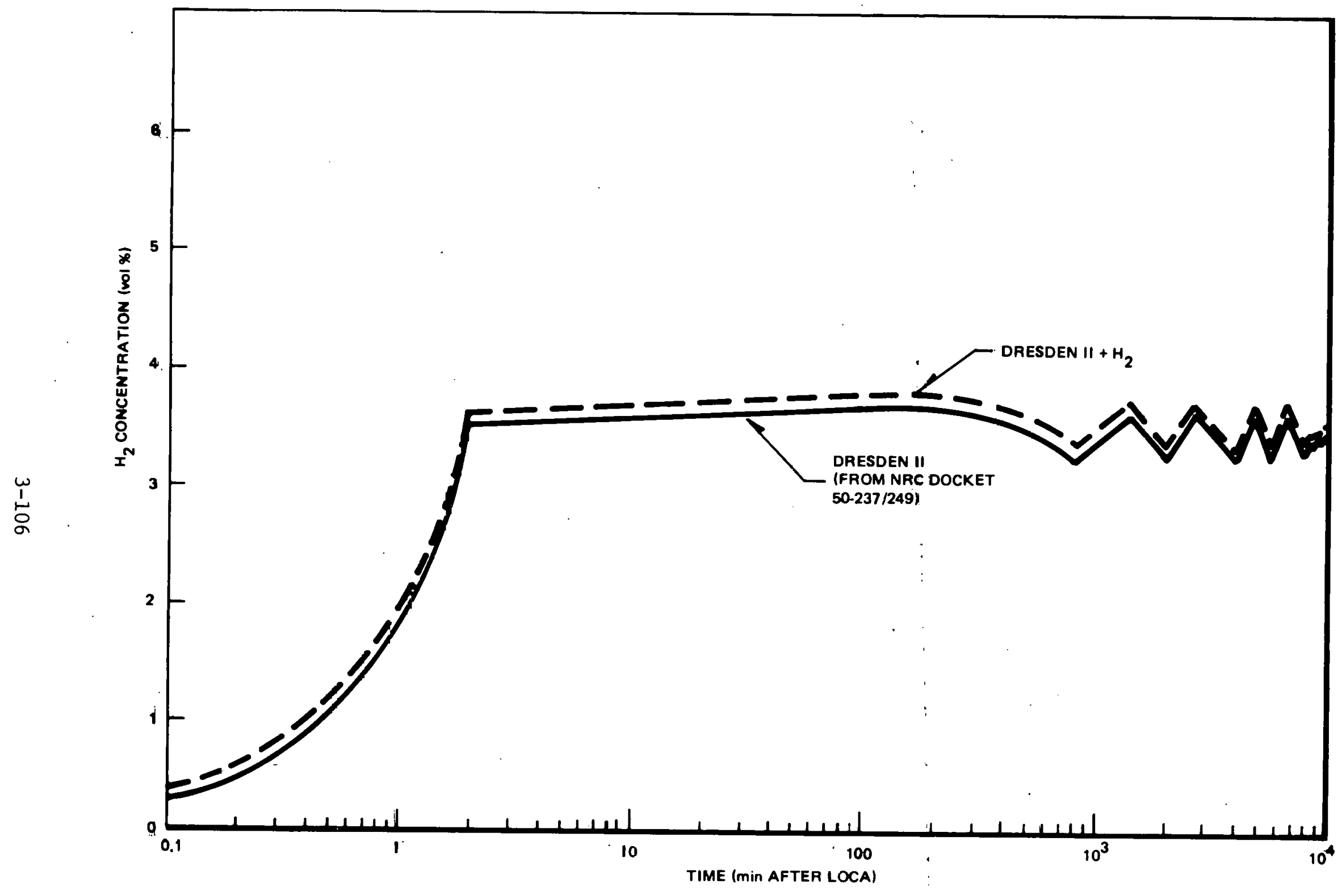

F-gure 3-32. Jrywell Hydrogen Concentration versus Time ffter LOCA 
Table 3-35

OPERATING CONDITIONS OF NEUTRAL, BOILING WATER LOOP TEST FROM AECL, -SEPTEMBER 1978

Exposure Time

Water Flow Rate

Pressure - Test Section Inlet

Temperature - At Outlet of Mixing Tee

- Test Section Inlet

- Test Section Outlet

Outlet Steam Quality

Water Chemistry - $\mathrm{pH}$

- Dissolved Hydrogen

- Crud Level

Neutron Flux - Thermal

- Fast

Fuel String Power - Gross
- Net (allowing for heat loss to core surroundings)

Surface Heat Flux, Maximum

Average Reynolds Number

In Fuel String
44.5 Effective Full Power Days

$0.75 \mathrm{~kg} / \mathrm{s}(1.651 \mathrm{bm} / \mathrm{s})$

$7.93 \mathrm{MPa}(1,150 \mathrm{psi})$

$278^{\circ} \mathrm{C}\left(532^{\circ} \mathrm{F}\right)$

$288^{\circ} \mathrm{C} \quad\left(550^{\circ} \mathrm{F}\right)$

$294^{\circ} \mathrm{C}\left(561^{\circ} \mathrm{F}\right)$

$11.3 \mathrm{wt} \%$

$7.3 \pm 0.3$

$>0.5 \mathrm{~cm}^{3} / \mathrm{kg}$

10 to $35 \mu \mathrm{g} / \mathrm{kg}$

$7.85 \times 10^{17} \mathrm{n} / \mathrm{m}^{2}$

$3.90 \times 10^{17} \mathrm{n} / \mathrm{m}^{2}$

$0.171 \mathrm{MW}$

$0.149 \mathrm{MW}$

$1.09 \mathrm{MW} / \mathrm{m}^{2}$

$1.0 \times 10^{5}$ (in trefoil bundle)

$2.3 \times 10^{5}$ (in single element) 
Table 3-36

FUEL DEPOSIT DATA FROM BOILING LOOP TEST

FROM AECL, SEPTEMBER 1978

\begin{tabular}{|c|c|c|c|c|c|}
\hline Bundle & & $\underline{\text { Element }}$ & $\begin{array}{l}\text { Surface } \\
\text { Heat Flux } \\
\left(\mathrm{MW} / \mathrm{m}^{2}\right) \\
\end{array}$ & $\begin{array}{l}\text { Steam } \\
\text { Quality } \\
\text { (wt \%) } \\
\end{array}$ & $\begin{array}{c}\text { Deposit Weight } \\
\text { of Iron } \\
\left(\mathrm{mg} / \mathrm{m}^{2}\right) \\
\end{array}$ \\
\hline \multicolumn{6}{|l|}{ Outlet } \\
\hline & 1 & 1 & - & 11.3 & 40 \\
\hline & & 2 & - & 11.3 & 38 \\
\hline & & 3 & - & 11.3 & 40 \\
\hline & 2 & 1 & 0.65 & 11.3 & 420 \\
\hline & & 2 & 0.65 & 11.3 & 580 \\
\hline & & 3 & 0.65 & 11.3 & * \\
\hline \multirow[t]{8}{*}{ F1ow } & 3 & 1. & 0.99 & 7.9 & 270 \\
\hline & 4 & 1 & 1.1 & 6.6 & 370 \\
\hline & & 2 & 1.1 & 6.6 & 330 \\
\hline & & 3 & 1.1 & 6.6 & 730 \\
\hline & 5 & 1 & 0.85 & 1.0 & 250 \\
\hline & 6 & 1 & 0.39 & 0.0 & 480 \\
\hline & & 2 & 0.39 & $u . u$ & 580 \\
\hline & & 3 & 0.39 & 0.0 & $590^{\circ}$ \\
\hline Inlet & & & & & \\
\hline
\end{tabular}


NEDC-23856-3

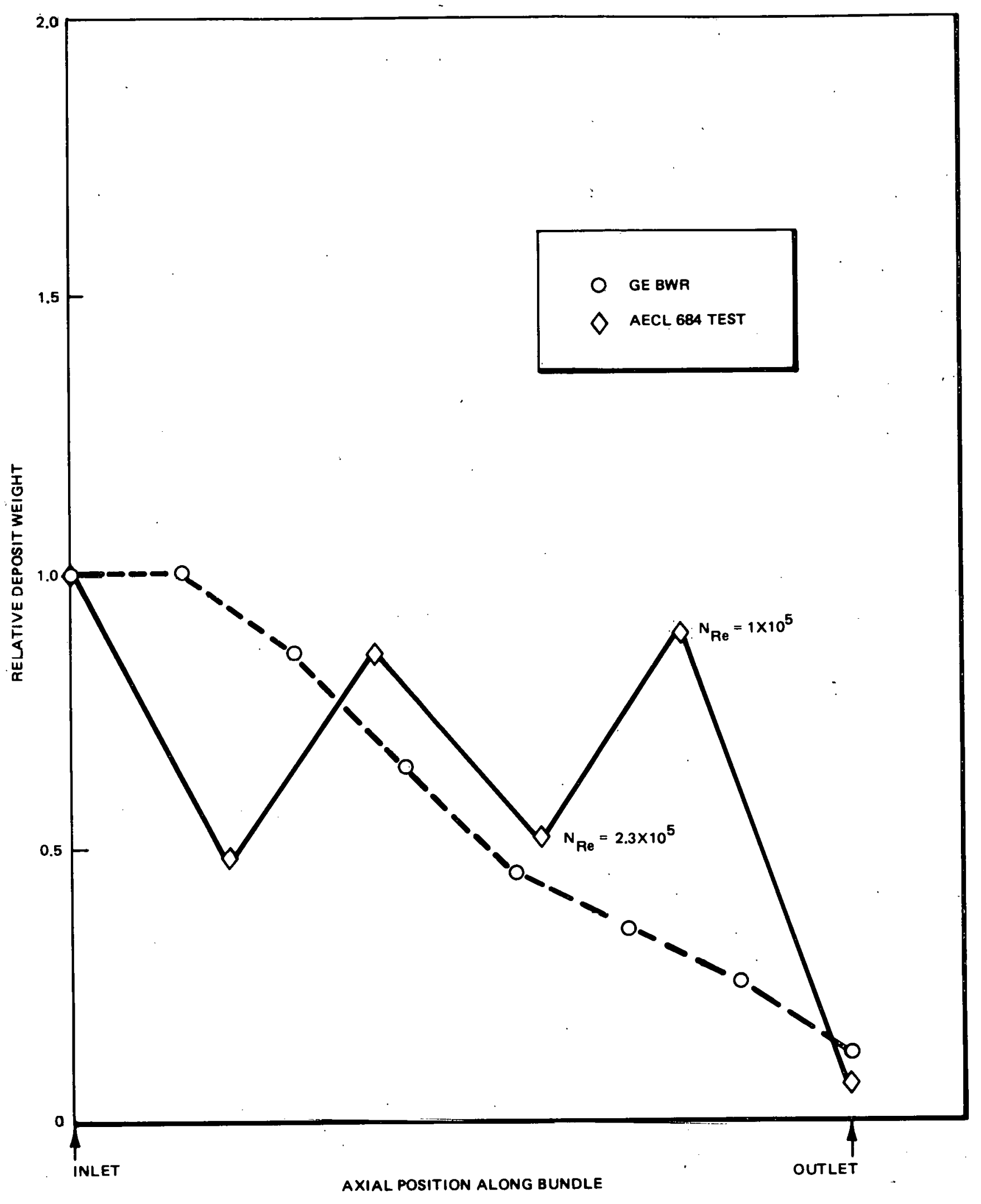

Figure 3-33. BWR Fuel Deposit Deposition 


\subsection{TASK B-9. ADDITIVE CONSUMPTION AND SOURCE (T. L. Wong)}

Objective. Predict the consumption of each additive as a function of required coolant concentration and the consequent increase in plant operating cost from the use of each of the chemicals.

The effurt on this task has been to obtain data on costs, recommended form and availability, and to determine whether any hydrogen recycle system should be further considered.

\subsubsection{Hydrogen Recyele}

The additive cost for hydrogen addition snuld he reduced by eeparating thc hydrogen form the offgas stream at a location upstream of the recombiner and then recycling the fairly pure hydrogen back to the injection system. Based on available technology, several processes have the capability for separating hydrogen trom the offgas. The swing-cycle adsorption process was discussed in a previous quarterly report. ${ }^{8}$ other potential hydrogen ${ }^{18}$ separation processes are discussed in the subsequent section.

\subsubsection{Membrane Separation Process}

The membrane process for separating hydrogen from nitrogen is based upon the relative permeation of gases through a membrane barrier. The membrane separation process is a continuous process which operates at ambient temperature, The process operates with a differential pressure across the membrane. Generally, a membrane unit operates under pressure on one side and at atmospheric pressure on the low pressure side.

F1gure 3-34 shows a schematic of a membrane separation unit. The feed gas consisting of nitrogen and hydrogen enters the unit at the high pressure side. The outlet gas from the unit is contained in two streams. One stream is hydrogen rich and the other stream is hydrogen-lean. The concentrations of hydrogen in the two streams are determined by the relative gas permeabilities and the available membrane area. 


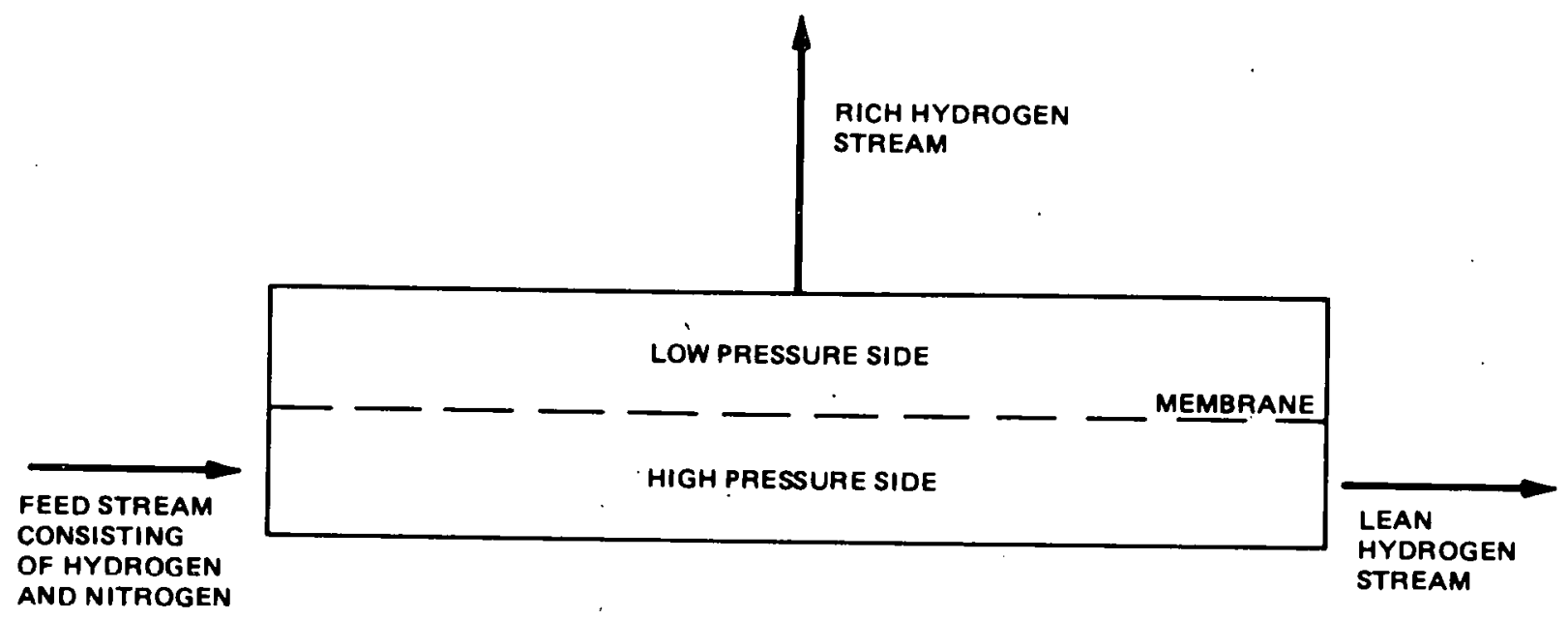

Figure 3-34. Membrane Separation Unit

In general, the large scale application of membrane separation had not materialized until recent years. This occurred after the development of technology for preparing hollow fibers. The utilization of hollow fibers permits the design and construction of membrane units with high effective membrane area to volume ratios and with the capability to withstand substantial pressure differentials.

For large-scale hydrogen separations, several membrane processes 25 exist. The Permasep Process developed by the DuPont Company consists of hollow fibers made of polymeric membrane. The hollow fibers are of the Dacron polyester type, $18 \mu \mathrm{i} . \mathrm{d}$. and 32 to $38 \mu \mathrm{o} . \mathrm{d}$. A module is constructed of millions of fibers encased in a steel shell rated at design pressure. A module is approximately $18 \mathrm{ft}$ long by $12 \mathrm{in.} \mathrm{i.d.} \mathrm{A} \mathrm{commercial} \mathrm{unit} \mathrm{has} \mathrm{been} \mathrm{operated} \mathrm{for} \mathrm{the} \mathrm{recovery}$ of hydrogen trom refinery gases. 


\subsubsection{Metallic Membrane Processes}

Other known large-scale hydrogen separation processes are the Union Carbide Hydrogen Purification and the Matthey Bishop Hydrogen Purification processes. These processes use metallic membranes made of palladium alloy. The Union Carbide process operates at a feed pressure of $500 \mathrm{psi}$ and temperatures of 300 to $400^{\circ} \mathrm{C}$ or higher. Gas impurities such as $\mathrm{CH}_{4}, \mathrm{C}_{2} \mathrm{H}_{6}, \mathrm{CO}$ and $\mathrm{H}_{2} \mathrm{~S}$ may have a deleterious effect on the membrane. Union Carbide operates their process to recover and purify hydrogen from olefins plants by-product fuel gas.

Matthey B1shop manufacturers and markets laboratory- and semi-scale hydrogen purification units made of $\mathrm{Ag}-\mathrm{Pd}$ (10 to 50\% silver) alloy membranes. Small units in the 10 to $50 \mathrm{scfh}$ range are available commercially: Laxger unirs such as a $1500 \mathrm{scfh}$ unit are available only on a custom-made basis.

\subsection{0 .4 System Size}

Calculations were made to size a hydrogen separation unit for concentrations and flow rates defined in the mass balance flow sheet for the $10 \mathrm{ppb}$ oxygen reactor water case. The calculations were made by assuming that the feed stream is a binary gas mixture consisting of hydrogen and nitrogen. The DuPont hollow fiber gas permeabilities ${ }^{20}$ of 165 and 3.1 [(cc) (cm) $\times 10^{-12} /$ (sec) $\left(\mathrm{cm}^{2}\right)$ (cmHg)] for hydrngen and nitrogen respeclively were used for these calculations. The concentrations of the effluent streams and the total membrane area requirements were estimated with a one-side mixing model. This model assumes plug flow for the feed stream which is introduced to the lnside of the hollow fibers and complete mixing for the permeate phase. The mass balance flow sheet estimated with the minimum hydrogen reject concentration is shown Figure 3-35 fur the membrane unit. The membrane area requirement tor a high pressure side of $1.0 \mathrm{~atm}$ and a low pressure side of 0.1 atm was estimated to be $8.9 \times 10^{6} \mathrm{ft}^{2}$. 


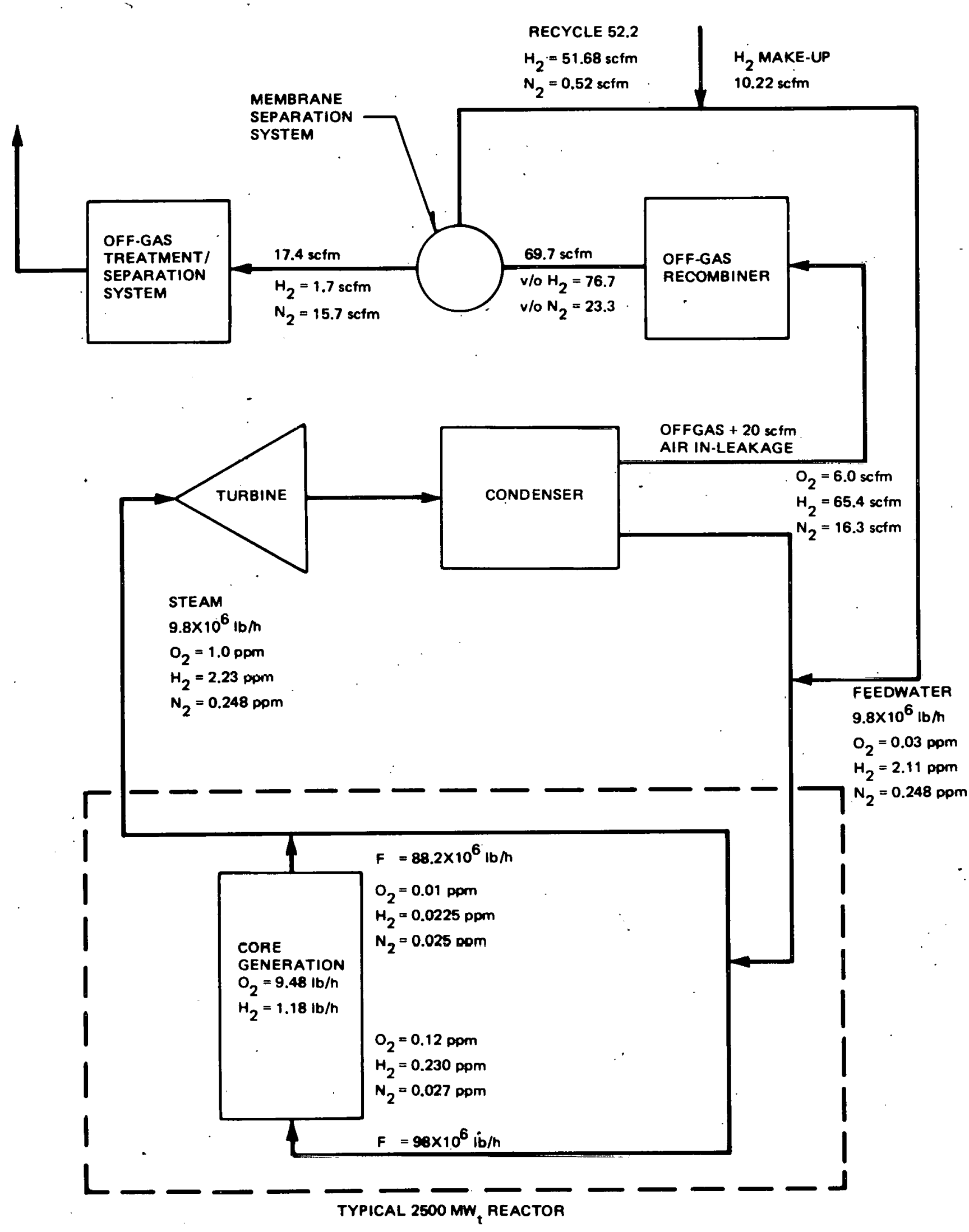

- Figure 3-35. Mass Balance Flow Sheet with Hydrogen Separation 


\subsubsection{Sponge Alloy Separations}

The use of metal hydrides for hydrogen storage has been a subject of research and development in recent years. Molycorp, Inc. proposes the use of rareearth-based materials such as lanthanum-nickel alloys to store hydrogen. These alloys at a given temperature and pressure will adsorb hydrogen deep into their atomic structures to form hydrides. The process is entirely reversible since at a lower pressure, hydrogen will be liberated as a gas. A lanthanum-nickel alloy ${ }^{26}$ has the capacity to store approximately $125 \mathrm{cc}$ of hydrogen per gram of alloy at 2 to 3 atm of pressure and $0^{\circ} \mathrm{C}$. Heat dissipation at the rate of approximately 13,000 Btu per lb mole of hydrogen adsorbed must be provided in the design of this type of hydrogen purification process. Based on available information large scale applination of this pructus has not yet materialized. 


\section{REFERENCES}

1. E. L. Burley "Oxygen Suppression in Boiling Water Reactors - Quarterly Report No. 2" October 1978, NEDC-23856-1.

2. E. L. Burley "Oxygen Suppression in Boiling Water Reactors - Quarterly Report No. 1", August 1978, NEDC-23856.

3. T. Mizuno, T. Kurosawa and M. Miyakawa, "Possibility of Reduction of Dissolved Oxygen with $\mathrm{N}_{2} \mathrm{H}_{4}$ ", unpublịshed paper.

4. Unpublished Communication, Roland Ivars of ASEA-ATOM to E. L. Burley $(8 / 28 / 78)$

5. D. R. Rogers "BWR Turbine Equipment N-16 Radiation Shielding Studies" General Electric Co. NEDO-20206.

6. Breden, C. R., "Boiling Water Reactor Technology Status of the Art Report. Volume II, Water Chemistry and Corrosion", ANL-6502 (Feb., 1963).

7. Whitham, G. K. and R. R. Smith, "Water Chemistry in a Direct-Cycle Boiling Water Reactor", Proc. of 2nd U.N. International Conference, Peaceful Uses of Atomic Energy, $7,430-444$ (1958).

8. Mih1, R. L. and M. H. Theys, "Radioactivity Buildup - N-16 Concentration in EBWR", Nucleonics, 19, 81-83 (1961).

9. Hammer, L., et. a1., "Water Chemistry Research at the Halden Boiling Heavy Water Reactor (HPWR)", HPR-55 (June, 1958).

10. Car1son, F., "Experiment R2-5519, Radiochemical Studies Concerning the Cooling Medium Under BWR Conditions", Report AE-MK-592 (1972).

11. Stenström, T., "On the Chemical Fate of Nascent ${ }^{11} \mathrm{C}$ Atoms Introduced by Irradiation of Water and Aqueous Solutions with $185 \mathrm{MeV}$ Protons", Ph.D. Theșis, Gustaf Werner Institute, Univ. of Uppsala, Uppsala, Sweden, 19.70 .

12. The chemical fate of $\mathrm{C}-15$ and $\mathrm{C}-14$ is expected to be identical to that observed by Stenstrom for $\mathrm{C}-11$.

13. Kolba, V., "EBWR Test Reports", ANL-6229 (Nov., 1960).

14. Bromberg, S. J. and C. E. Kent, "Boiling Water Reactor Process Environment.", NEDE-12577, Class III, Sept., 1975.

15. Kunz, C. O., W. E. Mohoney, and T. W. Miller, "Carbon-14 Gaseous Effluents from Boiling Water Reactors," ANS Transactions 21; 91 (1975). 
NEDC-23856-3

16. Cobble, J. W., "Chemical Thermodynamic Studies of Aqueous Trace Components in Light Water Reactors at High Temperature and Pressure, Part 1", Three Year Summary, EPRI Contract No. RP 311-2; San Diego State Univ. Foundation, March 15, 1978.

17. Sweeton, F. H., R. E. Mesmer, and C. F. Baes Jr., "Acidity Measurements at Elevated Temperatures, VII Dissociation of Water", J. Soln. Chem., 3 , 191 (1974).

18. E. L. Burley, "Oxygen Suppression In Boiling Water Reactors - Quarterly Report No. 3" March 1979 NEDC-23856-2.

19. Letter, S. G. Sawochka and D. T. Synder to W. L. Pear1, September 17, 1968.

20. Wang, K. B. and Ban, L. T. Chemical Engineering science, (1978) 33, pp. $945-952$.

21. Houghton, G., et. al. Chemical Engineering Science, (1957) 7, pp, 26-29.

22. Reed, R. C. and Sherwood, T. K. Properties of Gases and Liquids, 2nd Ed., McGraw-Hi11. 1966, pp. 18-20, 382, 520-556, 571 .

23. Nyberg, Paul. Private Communication, August 23, 1978.

24. Presberry, C. Solubility of Ideal Gases in Water, Y1002E101, BWR Chemical Technology Handbook. General Electric Co., 1977.

25. Hwang, S. T. and Kammermeyer; K., "Membranes in Separations", Techniques of Chemistry, Vol. VII, John Wiley \& Sons (1975).

26. Molycorp Bulletin - Overview 45, Hydrogen Energy Storage, Molycorp, Inc., 6 Corporate Park Drive, White Plains, N.Y. 
Appendix A

EQUIPMENT LIST - HYDROGEN INJECTION SYSTEM

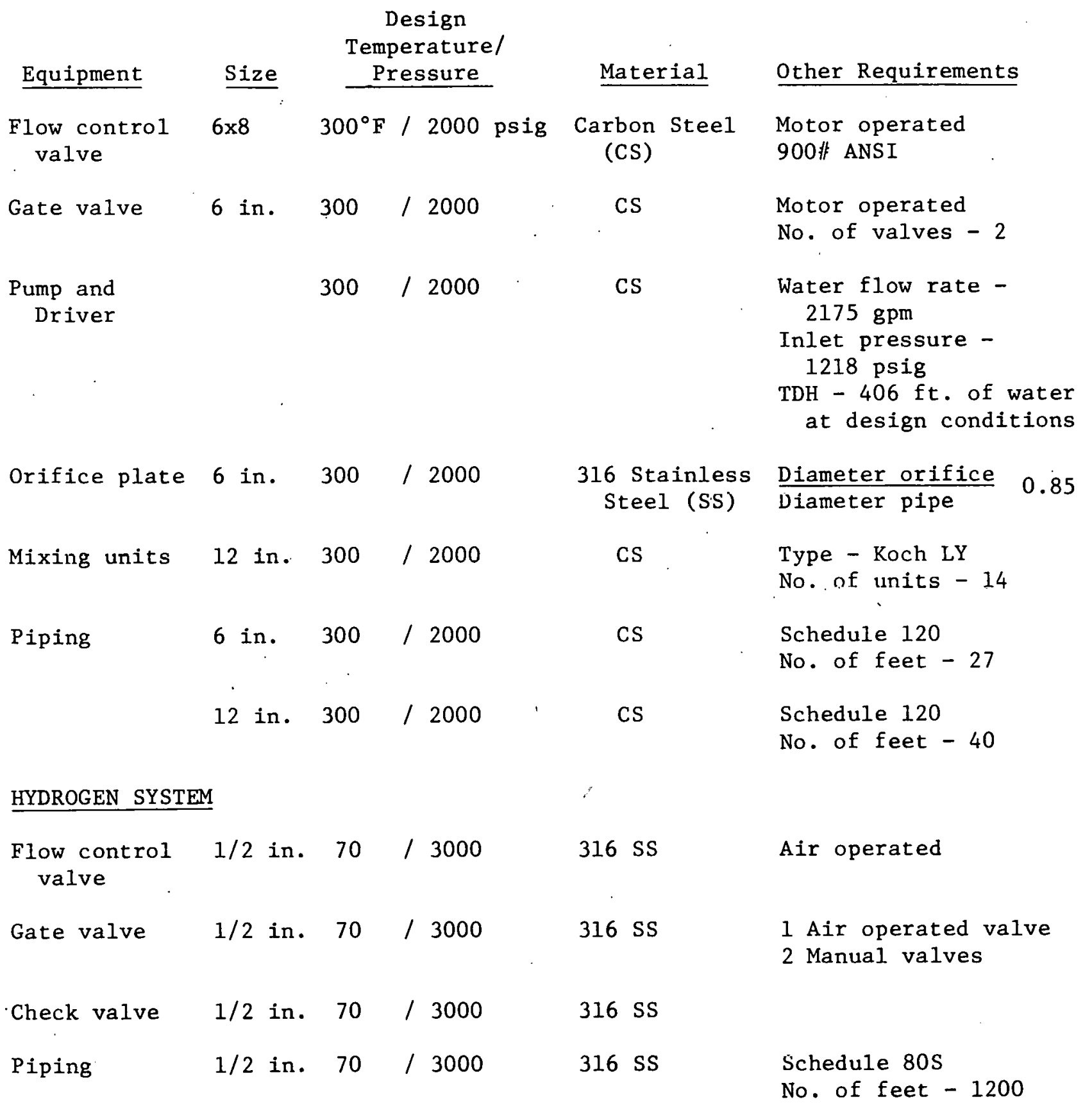


Appendix B

SAMPLE CALCULATIONS

The following is a listing of the various computations that were performed in the course of the design of the hydrogen injection system. The actual calculations were programmed into and completed on a Texas Instruments, Inc. TI-59, Programmable Calculator. Program listings are available on request.

Physical Properties of Hydrogen and Water

1. Density of Hydrogen at $\mathrm{T}=300^{\circ} \mathrm{F} ; \mathrm{P}=1200 \mathrm{psig}$

$$
\rho=0.2851 \mathrm{~b} / \mathrm{ft}^{3} \quad \text { (Reference } \mathrm{B}-1 \text { ) }
$$

2. Density of Water at $\mathrm{T}=300^{\circ} \mathrm{F} ; \mathrm{P}=1200 \mathrm{psig}$

$$
\rho=57.31 \mathrm{lb} / \mathrm{ft}^{3} \quad \text { (Reference B-2, Appendix 14) }
$$

3. Viscosity of water at $\mathrm{T}=300^{\circ} \mathrm{F} ; \mathrm{P}=1200 \mathrm{psig}$

$$
\mu=0.185 \mathrm{cp} \quad \text { (Reference B-2, Appendix 14) }
$$

\section{Calculation of Hydrogen-Water Diffusion Coefficient}

1. For gas dissolved in a liquid

$$
\frac{\mathrm{D}_{i j} \mathrm{x} \mu_{1}}{\mathrm{~T}_{\text {abs }}}=\text { constant } \quad \text { (Reference } \mathrm{B}-3 \text { ) }
$$

2. Diffusion of hydrogen into an aqueous solution at infinite dilution at $\mathrm{T}=25^{\circ} \mathrm{C} ; \mathrm{P}=1 \mathrm{~atm}$.

$$
D_{i j}=4.8 \times 10^{-5} \mathrm{~cm}^{2} / \mathrm{sec} \text { (Reference } \mathrm{B}-4 \text {, experimental) }
$$


3.

$$
\left.\mu_{1} \text { at } 25^{\circ} \mathrm{C}=0.9147 \mathrm{cp} \quad \text { (Reference } \mathrm{B}-5\right)
$$

4. Evaluation of the "constant"

$$
\begin{aligned}
\text { constant } & =4.8 \times 10^{-5} \times 0.9147 \times 10^{-2} / 298 \\
& =1.473 \times 10^{9} \mathrm{gm}-\mathrm{cm} / \mathrm{sec}^{2}-{ }^{\circ} \mathrm{K}
\end{aligned}
$$

5. Diffusion coefficient at $\mathrm{T}=300^{\circ} \mathrm{F} ; \mathrm{p}=1200 \mathrm{psig}$

$$
\begin{aligned}
D_{1 j} & =\text { constant } \times \text { Tabs } / \mathrm{u}_{1} \\
\mathrm{H}_{1} & =0.18 .5 \times 10^{-2} \mathrm{gm} / \mathrm{cm}-\mathrm{ser} \text { (Reference B-2, Appendix 14) } \\
\rightarrow D_{i j} & =1.473 \times 10^{-9} \times 422 . / 0.185 \times 10^{-2} \\
& =3.36 \times 10^{-4} \mathrm{~cm}^{2} / \mathrm{sec}
\end{aligned}
$$

Calculation of Length of Mixing Section for a Given Amount of Absorption

1. Design parameters

a. $23 \%$ of gas absorbed

b. Initial hydrogen flow is $301 \mathrm{~b} / \mathrm{hr}$

c. Pipe: 12-in. Schedule 120, i.d. = 10.75 in.

d. $\quad \mathrm{r}_{2}=0.285 \mathrm{lb} / \mathrm{ft}^{3}$

e. $\rho_{\mathrm{H}_{2} \mathrm{O}}=57.31 \mathrm{~b} / \mathrm{ft}^{3}$

f. $\quad P=92,5$ atm 
2. Calculation of $Q$

$$
Q=0.23 \times 30 / 60 \times 2=0.05751 \mathrm{~b} \mathrm{~mol} / \mathrm{min}
$$

3. Calculation of $\mathrm{A}$

$$
A=(10.75 / 12)^{2} \times \pi / 4=0.6303 \mathrm{ft}^{3}
$$

4. Calculation of $\overline{\mathrm{x}}$

$$
\begin{aligned}
& \text { a. } \mathrm{x}^{*}=\mathrm{P} / \mathrm{H}=92.5 / 4.9 \times 10^{4}=1.888 \times 10^{-3} \\
& \text { b. } \mathrm{x}_{\mathrm{i}}=0 \\
& \text { c. } \mathrm{x}_{\mathrm{f}}=30 \times 0.23 \times 18 / 9.77 \times 10^{5} \times 2=6.356 \times 10^{-5} \\
& \text { d. } \overline{\mathrm{x}}=\frac{\left(1.888 \times 10^{-3}-0\right)-\left(1.888 \times 10^{-3}-6.356 \times 10^{-5}\right)}{\ln \left(1.888 \times 10^{3} / 1.888 \times 10^{-3}-6.356 \times 10^{-5}\right)}=1.856 \times 10^{-3}
\end{aligned}
$$

5. Calculation of $\mathrm{K}_{\mathrm{L}}{ }^{\mathrm{a}}$

a. $\mathrm{V}_{\text {gas }}=(30-(30 \times 0.23)) / 60 \times 0.285 \times 0.6303$

$$
=2.1 \mathrm{ACFM} / \mathrm{ft}^{2}
$$

b. K $K_{L}$ d fur $\mathrm{O}_{2}-\mathrm{H}_{2} \mathrm{O}=7.5$ (Figure $3=28$ of main repurt)

$$
\text { c. } \begin{aligned}
\mathrm{K}_{\mathrm{L}} \text { a for } \mathrm{H}_{2}-\mathrm{H}_{2} \mathrm{O} & \left.=\mathrm{K}_{L^{a}}{ }^{\mathrm{a}} \mathrm{O}_{2}-\mathrm{H}_{2} \mathrm{O}\right) \times \frac{\mathrm{D}\left(\mathrm{H}_{2}-\mathrm{H}_{2} \mathrm{O}\right)}{\mathrm{D}_{\left(\mathrm{O}_{2}-\mathrm{H}_{2} \mathrm{O}\right)}} \\
& =7.5 \times \frac{3.36 \times 10^{-4}}{2.51 \times 10^{-5}} \\
& =100.5
\end{aligned}
$$


6. Calculation of Length, $L=Q / K_{L} a A \bar{x}$

$$
\begin{aligned}
L & =0.0575 / 100.5 \times 0.6303 \times 1.856 \times 10^{-3} \\
& =0.488 \mathrm{ft}
\end{aligned}
$$

Generation of Hydrogen Absorption Curve for Koch Static Mixers

1. Determine value of constant from $L=0.488$ ft for $23 \%$ absorption

$$
C=\mathrm{L} / \ln (1-\text { abs })=0.488 / \ln (1-0.23)=1.8
$$

2. Computation of hydrogen adsorption curve

$$
\mathrm{L}=\mathrm{C} \ln (1-\mathrm{abs})
$$

Table B-1 summarizes the results for $L$ versus various values for abs.

\section{Calculation of Pressure Drop Through Hydrogen Injection Side Stream Loop}

1. $\Delta \mathrm{P}$ for entrance and exit piping

$\Delta \mathrm{P} / \mathrm{L}=0.00000336 \times \frac{\mathrm{f} \times \mathrm{W}^{2}}{\mathrm{~d}^{5} \times \rho}($ Reference $\mathrm{B}-6, \mathrm{p} \cdot 3-2)$

$\Delta \mathrm{P} / \mathrm{L}(\mathrm{G}$ in. Echedule 120$)-3.36 \times 10^{-6} \times \frac{0.0165 \times\left(9.77 \times 10^{5}\right)^{2}}{5037 \times 57.3}$

$$
=0.1833 \mathrm{psi} / \mathrm{tt}
$$

$\Delta \mathrm{P} / \mathrm{L}(12-\mathrm{in}$. Schedule 120) $=0.00546 \mathrm{psi} / \mathrm{ft}$ 


\section{Table B-1}

MIXING L'ENGTH VERSUS HYDROGEN ABSORPTION

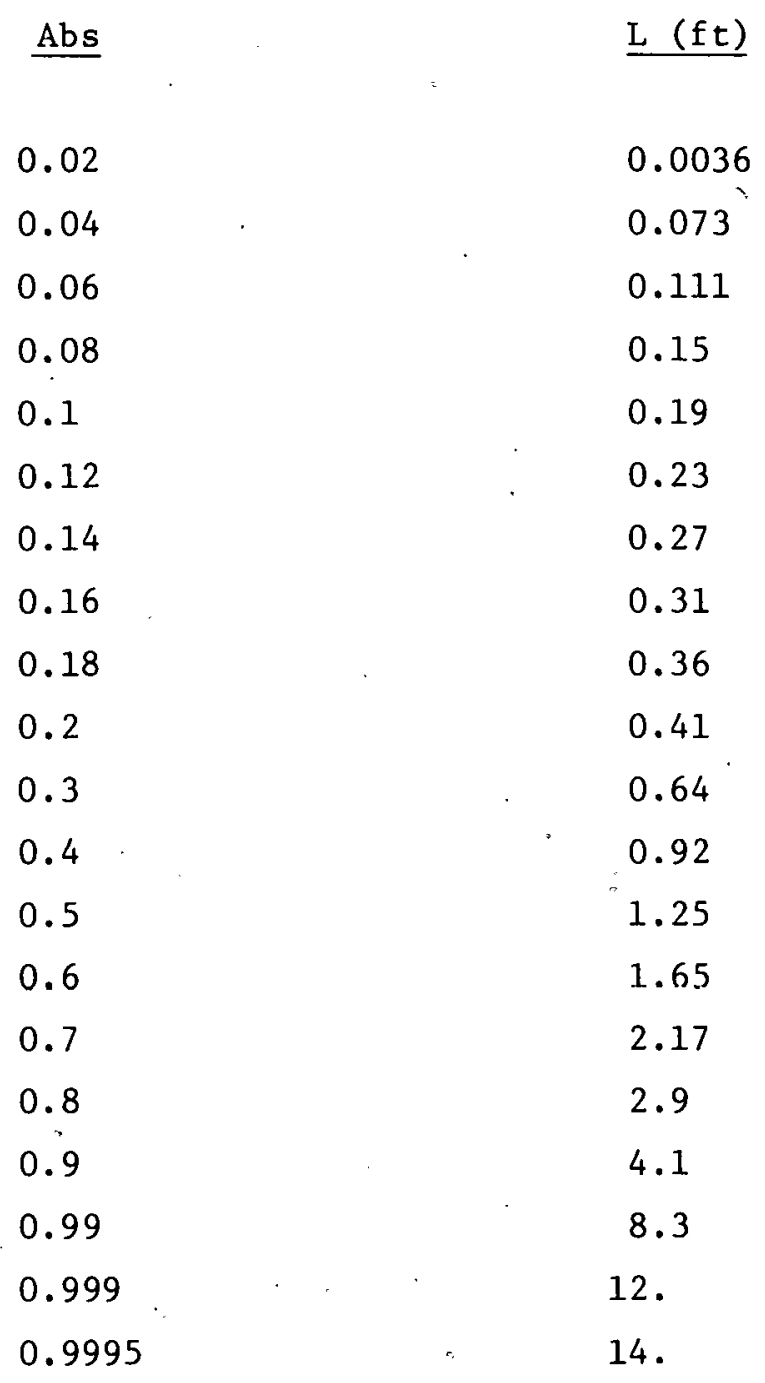

2. $\Delta \mathrm{P}$ for $90^{\circ}$ long radius elbows

$$
\begin{aligned}
& \Delta \mathrm{P}=0.00000028 \times \frac{\mathrm{K} \times \mathrm{W}^{2}}{\mathrm{~d}^{4} \times \rho} \quad(\text { Reference } \mathrm{B}-6, \mathrm{p} 3-4) \\
& \text { but } \mathrm{K} \cdot=\mathrm{f} \mathrm{L} / \mathrm{D} \\
& \text { and } L / D=20 \\
& \text { (Reference } B-6, P \cdot A-30 \text { ) } \\
& \text { so } \\
& \Delta P=2.8 \times 10^{-7} \times 20 \times \mathrm{f} \times \mathrm{w}^{2} / \mathrm{d}^{4} \times \rho
\end{aligned}
$$




$$
\begin{aligned}
\Delta \mathrm{P}\left(6^{\prime \prime}\right) & =2.8 \times 10^{-7} \times 20 \times \frac{0.0165 \times\left(9.77 \times 10^{5}\right)^{2}}{915.7 \times 57.3} \\
& =1.68 \mathrm{psi} \\
\Delta \mathrm{P}\left(12^{\prime \prime}\right) & =0.0978 \mathrm{psi}
\end{aligned}
$$

3. $\Delta \mathrm{P}$ for gate valves

$$
\begin{aligned}
& \text { with } L / D=13 \\
& \qquad \begin{aligned}
\Delta P & =2.8 \times 10^{-7} \times 13 \times \mathrm{f} \times \mathrm{W}^{2} / \mathrm{d}^{4} \times \rho \\
& =1.09 \mathrm{psi} \text { (ft 6-in. valve) }
\end{aligned}
\end{aligned}
$$

4. $\Delta \mathrm{P}$ for entrance and exit effects

with $\mathrm{K}=0.04$ for well-rounded entrance and

$\mathrm{K}=1.00$ for well-rounded exit

(Reference $\mathrm{B}-6, \mathrm{P}, \mathrm{A}-26$ )

$$
\begin{aligned}
\Delta \mathrm{P} & =2.8 \times 10^{-7} \times 1.04 \times \mathrm{W}^{2} / \mathrm{d}^{4} \times \rho \\
& =5.30 \mathrm{psi} \text { (for 6-in. Schedule } 120 \mathrm{pipe})
\end{aligned}
$$

5. $\Delta \mathrm{P}$ for expansion and contraction effects

$$
\begin{aligned}
& \text { with } \mathrm{K}=0.545 \text { for a } 6^{\prime \prime} \times 12^{\prime \prime} \text { expansion and (Reference B-6, p. A-26) } \\
& \mathrm{K}=0.33 \text { for a } 6^{\prime \prime} \times 12^{\prime \prime} \text { contraction } \\
& \qquad \begin{aligned}
\Delta \mathrm{P} & =2.8 \times 10^{-7} \times 0.875 \times \mathrm{W}^{2} / \mathrm{d}^{4} \times \rho \\
& =4.46 \mathrm{psi}
\end{aligned}
\end{aligned}
$$

6. $\Delta \mathrm{P}$ for flow measuring orifice

$$
\left.\Delta \mathrm{P}=\left(\mathrm{W} / 1891 \times \mathrm{d}_{\mathrm{o}}^{2} \times \mathrm{C}\right)^{2} \times 1 / \rho \quad \text { (Reference } \mathrm{B}-6, \mathrm{p} \cdot 3-5\right)
$$




$$
\begin{aligned}
& \text { with } \begin{aligned}
\mathrm{d}_{\mathrm{O}} & =4.676^{\prime \prime}, \mathrm{d}_{\mathrm{o}} / \mathrm{d}_{1}=4.676 / 5.501=0.85 \\
\text { and } \mathrm{C} & =0.83 \\
\qquad \mathrm{P} & =\left(9.77 \times 10^{5} / 1891 \times 4.676^{2} \times 0.83\right)^{2} / 57.3 \\
& \quad \text { (Reference B-6, } \mathrm{p} \cdot \mathrm{A}-20) \\
& =14.1 \mathrm{psi}
\end{aligned}
\end{aligned}
$$

but actual pressure drop is $34 \%$ of this value (Reference B-7, p. 12)

$$
\Delta \mathrm{P}=14.1 \times 0.34=4.8 \mathrm{psi}
$$

7. $\Delta \mathrm{P}$ for mixing section

$$
\begin{aligned}
\rightarrow \quad \Delta \mathrm{P} / \mathrm{L} & =3.6 \times 10^{-5} \times \mathrm{f} \times \mathrm{v}^{2} / \mathrm{d}_{\mathrm{H}} \quad \text { (Reference B-8) } \\
& =3.6 \times 10^{-5} \times 0.19 \times 57.3 \times 94.96^{2} / 1.19 \\
& =2.97 \mathrm{psi} / \mathrm{ft}
\end{aligned}
$$

The above pressure drops are summarized in the following table.

Table $B-2$

SYSTEM PRESSURE DROPS

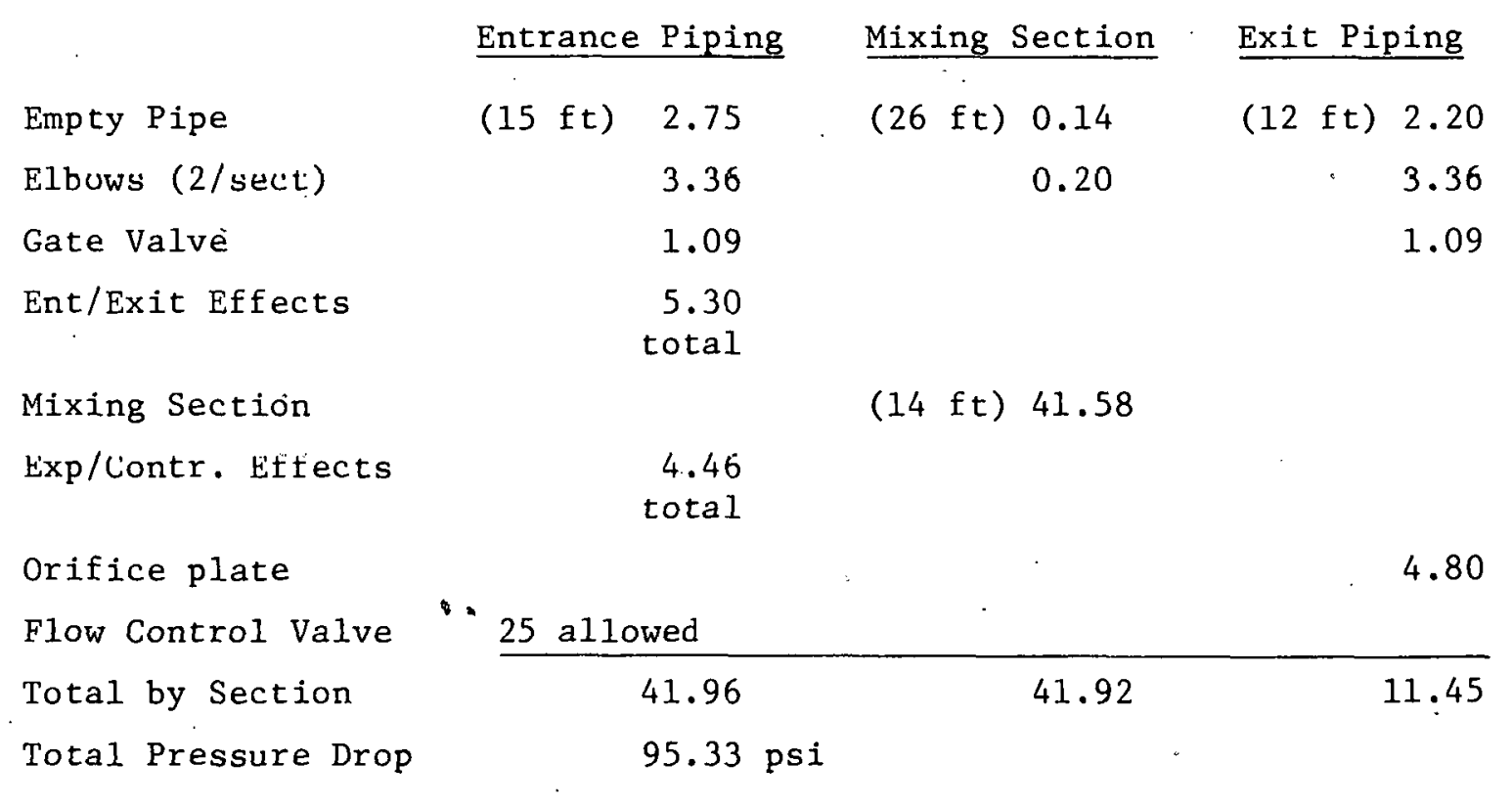


NEDC-23856-3

\section{Calculation of Side Stream Pump Size}

1. Water horsepower

$$
\begin{aligned}
\mathrm{P}_{\text {wat }} & =\mathrm{Q} \times \mathrm{P} / 1714 \\
\therefore \quad & =2126 \times 162 / 1714 \\
& =201 \mathrm{hp}
\end{aligned}
$$

2. Brake horeepower

$$
\begin{aligned}
\text { BHP } & =P_{\text {wat }} / \text { efficiency } \\
& =201 / 0.6 \\
& =335 \mathrm{hp}
\end{aligned}
$$

(Reference B-6, P. B-9)

0 


\section{References - Appendix B}

B-1. Properties of Principal Cryogenics, 3rd. Part., 1966, pp. 111-2.

B-2. McCabe, W. L. and Smith, J. C. Unit Operations of Chemical Engineering, 3rd Ed., McGraw-Hill. 1976, pp. 732, 697 .

B-3. McCarty, T. D. Hydrogen Technological Survey - Thermophysical Properties. NASA SP-3089, 1975, pp. 102-103.

B-4. Reed, R. C. and Sherwood, T. K. Properties of Gases and Liquids, 2nd Ed., McGraw-Hill. 1966, pp. 18-20, 382, 520-556, 571.

B-5. Bird, R. B., Stweard, W. E., and Lightfoot, E. N. Transport Phenomena. John Wiley \& Sons. 1970, pp. 8.

B-6. Crane Technical Paper 'No. 410, 1969.

B-7. American Society of Mechanical Engineers, Power Test Code, 19.5; 4-1959. Flow Measurement - Part 5, Measurement of Quantity of Materials.

B-8. Pluess, R. C. Pressure Drop Calculations on Koch Static Mixing Units, Revision 1. Koch Engineering Co. 1977. 


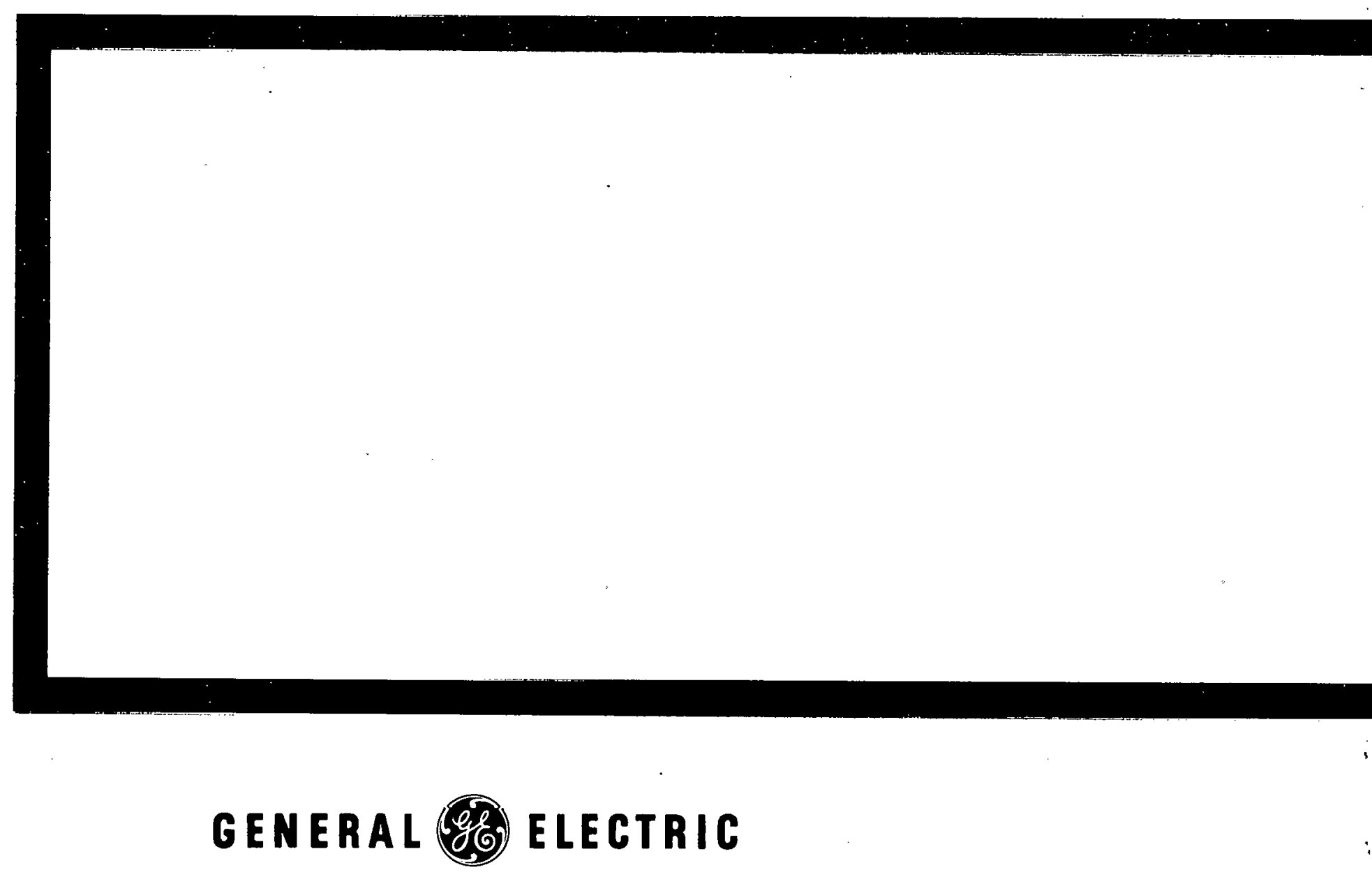

